Glaudionor Gomes Barbosa

\title{
ECONOMIA BRASILEIRA RECENTE (1980-2019)
}

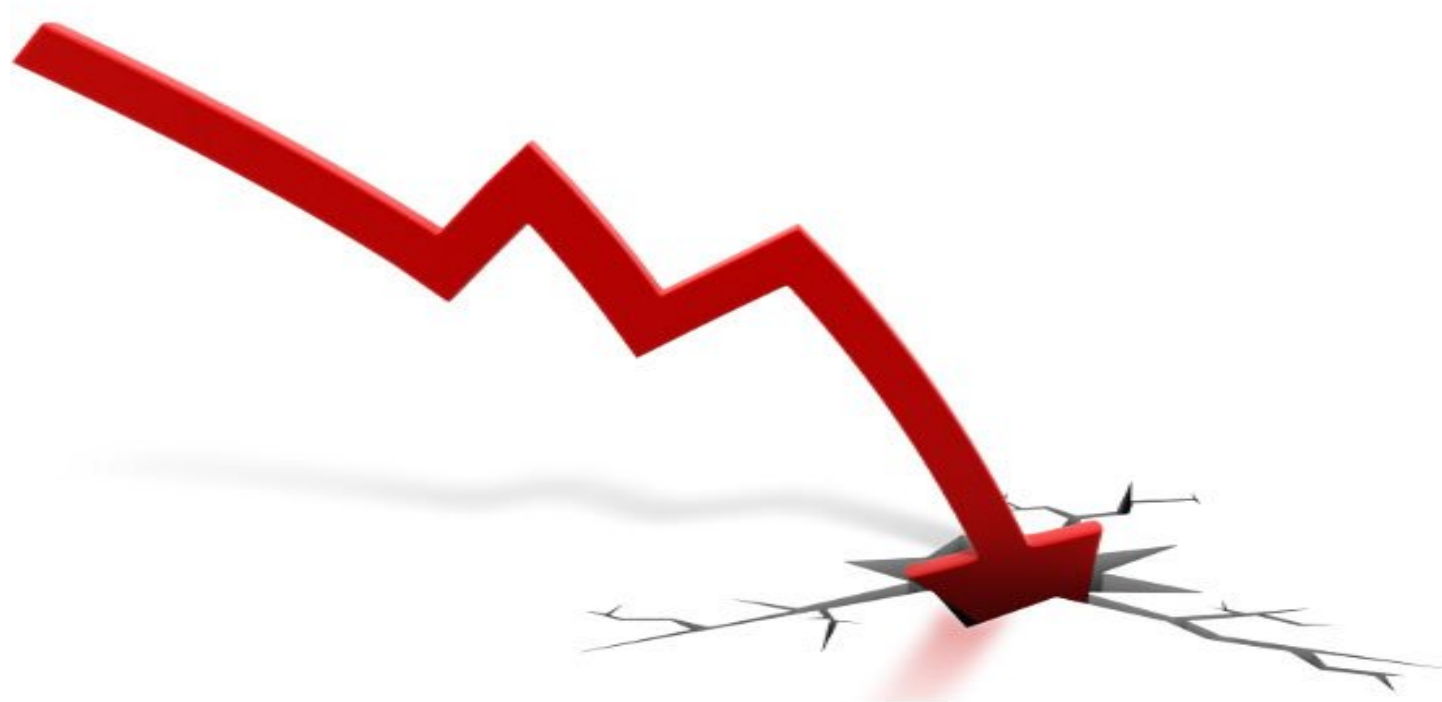

EDITORA EVEN3 
Glaudionor Gomes Barbosa

\section{ECONOMIA BRASILEIRA RECENTE (1980-2019)}

$1^{\mathrm{a}}$ Edição

Recife

2019

EVEN3 EDITORA 
Dados Internacionais de Catalogação na Publicação (CIP) (Even3 Publicações, PE, Brasil)

\section{BA238e BARBOSA, Glaudionor Gomes.}

Economia Brasileira Recente (1980-2019). / Glaudionor Gomes Barbosa. - 1. ed. - Recife: Even3 Publicações, 2019. 1 livro digital ; $90 \mathrm{p}$.

Modo de acesso: Internet.

DOI: $10.29327 / 510601$

ISBN: 978-85-57223-59-2

1. Economia Brasileira. 2. Ciências Econômicas. 3. História Econômica. I. Título.

CDD 330

CDU 338.1 


\section{Sumário}

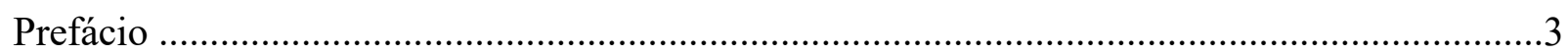

Capítulo 1 - Os anos oitenta: a "década perdida" .............................................................. 5

Capítulo 2 - Os anos noventa: a "década mais que perdida" .................................................21

Capítulo 3 - O período 2003-2010: a recuperação nacional restringida ....................................35

Capítulo 4 - Conportamento e absorção externa e a incorporação tecnológica ........................56

Capítulo 5 - A economia brasileira na década atual ou crônica de um desastre anunciado .......62

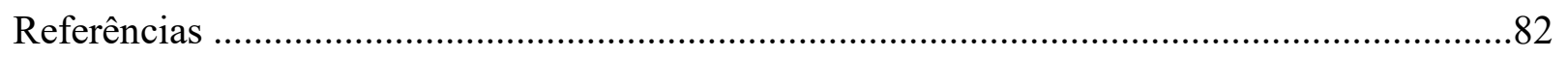




\section{Prefácio}

Vivemos tempos horríveis, nefastos. De qualquer ponto que se observe, a atual situação brasileira, não há diagnóstico ou prognóstico positivo a curto prazo.

Consumado o Golpe de 2016, a sensação é a de acordar após um desastre de carro. A consciência vai voltando aos poucos. Os danos vão sendo identificados, um a um, e dolorosamente contabilizados. Checam-se os pontos das condições físicas, mentais e psíquicas, após o trauma. Quais as perdas? Quais as permanências? Movimentos dos pés, mãos, pescoço? Essa enorme dor de cabeça, e o gosto de sangue na boca, que cospe algo como um dente ou pedaço de vidro... que teria acontecido? E então se abrem os olhos, e a mente em retrospectiva.

Estávamos indo bem. No início deste século, o Brasil se apresentava como uma promessa civilizatória. A descoberta do princípio econômico da divisão do trabalho, ainda que com pouco mais de duzentos anos de atraso, estava fazendo maravilhas pelo nível de emprego, demanda efetiva, crescimento, desenvolvimento e até pela distribuição de renda. A uma estratégia de política externa bastante engenhosa, com multipolaridade e participação ativa, generosa e inclusiva no cenário internacional, juntaram-se lances fortuitos de sorte, como a descoberta de reservas petrolíferas no pré-sal. Os problemas no horizonte pareciam questões de ajuste. Podíamos relaxar, o Brasil estava no caminho.

Então, veio o golpe. A participação aberta dos EUA no processo é uma questão de intensidade, a ser discutida no futuro da historiografia mais ou menos informada. Só nega sua origem hoje quem dele participa como cúmplice.

$\mathrm{Na}$ atualidade, vejo duas maneiras de observar o Golpe em curso, do ponto de vista de quem dele não se beneficia e compartilha do mesmo sonho de civilização que o Brasil oferece em sua potencialidade. Uma primeira é assumir o clássico papel de vítima de mais uma rodada, mais um "rapa" do imperialismo, por sobre a América Latina. Somos vítimas disso, em uma nova imposição do velho papel subserviente que o império demanda. Aos fatos dados, à destruição e pilhagem de nossas riquezas mais uma vez comandadas, aquiescemos entre a pusilanimidade e a impotência. Essa visão reúne uma miopia de curto prazo e até certa cumplicidade com o estado de coisas. Uma cumplicidade masoquista, suicida em seu limite.

Outra maneira parte de identificarem-se eventuais desvios e erros na estratégia adotada. Sermos golpeados uma vez, é culpa de quem nos golpeou. Que isso aconteça conosco novamente, é responsabilidade nossa. E ela está presente, nessa nova rodada, com a reprimarização de nossa economia, com a opção pelo agronegócio, com a tentativa de conciliação junto ao capital usurário (golpista desde e para sempre), e a completa ausência de uma tática responsiva a movimentos historicamente conhecidos desde a metade do século passado, com Getúlio Vargas, João Goulart, e agora com Dilma Rousseff. A base estrutural da "lição de casa" que deveríamos ter feito - mudar o primarismo, a extensividade, investir no mercado interno e na 
eficiência marginal do capital produtivo a circular domesticamente - não foi mais do que arranhada, antes que fôssemos surpreendidos por mais um golpe no script traçado pela inteligência metropolitana. Sem a mobilização de setores populares, sem a democratização do controle e uso do poder de contenção e coerção de massas, e sobretudo sem uma política efetiva de força, da parte dos setores progressistas quando no poder, o Brasil será objeto dessa anedota golpista que ora se repete, não apenas por ele, mas por toda a América Latina.

Assim, este livro do Professor Glaudionor Barbosa é um convite não apenas à reflexão subsidiada e ao entendimento de nosso papel e lugar no mundo e na história, mas também à ação. Deve ser por isso, aliás, que Glaudionor resolveu empunhar, mais uma vez, a velha pena, à clava forte, como bom filho que não foge à luta.

São Luís, Maranhão, novembro de 2019.

Luiz Eduardo Simões de Souza

Historiador Econômico 


\section{Capítulo 1}

\section{Os anos oitenta: a "década perdida"}

\section{O último Delfim e a crise dos primeiros anos oitenta}

A vitória do Presidente Ernesto Geisel e do seu grupo político sobre a extrema-direita militar no processo sucessório não foi completa, pois requereu negociações internas dentro do "núcleo duro". As negociações exigiram concessões mútuas, que incluiu o nome do general João Baptista Figueiredo como sucessor de Geisel. O general Figueiredo não estava inteiramente comprometido com o projeto autonomista expresso no II PND.

A economia brasileira encontrava-se em pleno crescimento resultante do amadurecimento dos investimentos públicos implementados pelo II PND. O PIB, que no milagre cresceu na média anual de 11,0\%, cresceu em quase 6,0\% no período de marcha forçada, ou seja, 1974-1978. Em 1979 o crescimento foi de 7,2\% e em 1980 bateu a casa dos $9,0 \% .{ }^{1}$ O que se tenta mostrar é que o crescimento da economia brasileira era satisfatório. A crise foi fundamentalmente um fenômeno externo e de ajustamento do capitalismo mundial. Os países do núcleo orgânico do sistema-mundo, observando a queda na taxa de lucro, resolveram jogar o peso da crise sobre os países periféricos e semiperiféricos. Os mecanismos de transferência da crise foram aumentos na taxa de juros internacional e redução na taxa de intercâmbio.

Depois de premiado com a embaixada brasileira em Paris, o economista Antônio Delfim Neto, o mago do chamado "milagre econômico brasileiro" (1968-1973), foi chamado de volta para ocupar a pasta da agricultura. É difícil saber se o último Delfim visava apenas uma reordenação nas macropolíticas agrícolas em um momento em que o país precisava de uma maior oferta alimentar capaz de reduzir as pressões inflacionárias, além de necessitar um aumento no esforço exportador, ou se a intenção presidencial era de criar um contraponto às políticas extremamente ortodoxas da dupla Mário Henrique Simonsen e Karlos Rischbiter. Intencional ou não o conflito se colocou de pronto, reproduzindo uma polaridade histórica do Estado brasileiro, a saber: os desenvolvimentistas perseguindo o crescimento e os conservadores preocupados com a "solidez dos fundamentos macroeconômicos”. Os 120 anos republicanos poderiam ser escritos apenas

\footnotetext{
${ }^{1}$ Os dados são do IBGE e do BACEN
} 
baseados nesta luta interna, enquanto um conflito de mentalidades, ou enquanto um conflito intraclasse da burguesia.

Delfim Neto imediatamente substituiu Simonsen na Pasta do Planejamento e tentou reeditar, mesmo que em escala menor, o milagre. A difícil situação internacional somada aos problemas internos não só impediram qualquer reedição, mesmo que pálida dos excelentes anos que vão de 1968 a 1973, como precipitaram a crise. O fracasso obrigou Delfim Neto a comandar uma política econômica tão ortodoxa e recessiva quanto a que era propugnada por Simonsen.

Em 1980, o PIB cresceu 9\%, contudo, em 1981 caiu 3\% promovendo uma onda errática de $12 \%$ em dois anos. A política de aceleração promovida por Delfim era equivocada, entre outros motivos por ter criado expectativas irrealistas. De todo modo a recessão veio a partir de 1981e trouxe como principal resultado o aprofundamento da crise de legitimidade do regime militar, de maneira a não restar dúvida de que João Batista Figueiredo seria o último general- presidente.

A política macroeconômica que prevaleceu em 1981 e 1982 foi basicamente direcionada para a redução das necessidades de divisas estrangeiras através do controle da absorção interna. A lógica dessa política é fazer com que a queda da demanda interna torne as atividades exportadoras mais atraentes, ao mesmo tempo em que reduz as importações. [...] A política a ser seguida baseava-se na contenção salarial, no controle dos gastos do governo e no aumento da arrecadação, na elevação das taxas de juros internas e na contração da liquidez real, sem abrir mão do tratamento especial dado as atividades de exportações, energia e agricultura e às pequenas empresas. (CARNEIRO \& MODIANO, 1992: 324-325).

Quando o dilema entre continuar o crescimento com um mínimo de autonomia frente ao núcleo orgânico ou proceder ao ajuste recessivo sob o comando do FMI se colocou, as poucas convicções desenvolvimentistas do general-presidente Figueiredo foram vencidas, ou seja, a filosofia econômica contida no II PND foi abandonada. A única forma de evitar a ida ao Fundo 
dado o tamanho da dívida, era decretando uma moratória soberana, não havia disposição política para tal. Unir as forças do empresariado em um projeto de crescimento com responsabilidade foi exatamente o que o ministro Delfim anunciou, pelo menos como retórica: crescimento econômico com controle inflacionário.

As medidas que aparentemente visavam a expansão econômica podem assim ser enumeradas:

(a) desvalorização cambial de 30\% como mecanismo estimulador das exportações;

(b) maiores estímulos à exportação;

(c) redução do Imposto de Renda sobre remessas de lucros para o exterior de $12,5 \%$ para $1,5 \%$, para facilitar a entrada de capitais externos;

(d) criação de um imposto sobre as exportações agrícolas beneficiadas pela desvalorização cambial a fim de transferir estes recursos para outros setores descapitalizados;

(e) maiores facilidades de crédito na aquisição de bens de consumo duráveis;

(f) ampliação de crédito para capital de giro das empresas;

(g) implementação de políticas de reativação do setor de construção civil;

(h) maiores e melhores créditos para o setor agrícola;

(i) redução de custos financeiros no financiamento de bens duráveis de consumo, tais como: redução do IOF e liberação do limite de crédito.

Das medidas que buscavam combater o componente inflacionário, devem-se destacar as seguintes:

(a) corte nos gastos da União e das empresas estatais;

(b) eliminação dos subsídios às exportações;

(c) extinção dos juros subsidiados;

(d) redução dos mecanismos protecionistas;

(e) aumento do preço do crédito e, em alguns casos, corte creditício;

(f) ajustes na política salarial.

Além das inconsistências entre medidas propostas, como estímulo às exportações e eliminação dos subsídios às exportações, deve-se registrar que as principais medidas visavam aumentar o saldo em moeda internacional para pagamento da dívida externa e/ou formação de reservas cambiais.

A tabela 1 mostra que os superávits comerciais deveram-se mais a redução das Importações, que caíram em mais de 40\% entre 1980 e 1985 do que ao crescimento das Exportações, algo em torno 
de 25\% no mesmo período. Por outro lado, a Formação Bruta de Capital Fixo (FBKF) caiu de 22\% do PIB para 16\%, o que indica claramente as dificuldades desta quadra histórica. Ou seja, sem investimentos a economia não anda.

\author{
Tabela 1 \\ Indicadores Selecionados \\ Brasil \\ 1980 \\ 1985
}

(Taxa de Variação Percentual em relação ao ano anterior exceto quando se especifica de outra forma)

\begin{tabular}{|c|c|c|c|c|c|c|c|}
\hline Ano & $\begin{array}{c}\text { PIB } \\
\text { (1) }\end{array}$ & $\begin{array}{c}\text { FBKF } \\
\text { (2) }\end{array}$ & $\begin{array}{c}X \\
10^{6} \mathrm{USS} \\
(3)\end{array}$ & $\begin{array}{c}M \\
10^{6} \mathrm{USS} \\
(4)\end{array}$ & $\begin{array}{c}\text { Balança } \\
\text { Comercial } \\
\text { (5) }\end{array}$ & Inflação & $\begin{array}{l}\text { Salário } \\
\text { Mínimo } \\
\text { Real (6) }\end{array}$ \\
\hline 1980 & 9,1 & 22,5 & 20132,4 & 22955,2 & $-2822,8$ & 82,8 & 2,5 \\
\hline 1981 & $-3,1$ & 21,0 & 23293,0 & 22090,6 & 1202,4 & 105,6 & $-1,9$ \\
\hline 1982 & 1,1 & 20,4 & 20175,1 & 19395,0 & 780,1 & 98,0 & 0,7 \\
\hline 1983 & $-2,8$ & 16,1 & 21899,3 & 15428,9 & 6470,4 & 142,0 & $-10,2$ \\
\hline 1984 & 5,7 & 15,5 & 27005,3 & 13915,5 & 13089,5 & 196,7 & $-8,8$ \\
\hline 1985 & 8,4 & 16,7 & 25639,0 & 13153,5 & 12485,5 & 227,0 & $-10,1$ \\
\hline
\end{tabular}

Fonte: IBGE e BACEN

Notas:

(1) Produto Interno Bruto;

(2) Formação Bruta de Capital Fixo;

(3) Exportações;

(4) Importações;

(5) Balança Comercial = X $-\mathrm{M}$;

(6) Salário Mínimo Real = Salário Nominal corrigido pelo Deflator Implícito do PIB.

Passadas as eleições de 1982 não restava nenhum a dúvida de que o Brasil iria ao Fundo (FMI). A única saída para o governo militar no apagar das luzes era negociar com o Fundo Monetário Internacional. Foram sete cartas de intenção em vinte e quatro meses. O verdadeiro pomo da discórdia entre as autoridades brasileiras e os agentes do capital financeiro internacional era quanto a proposta defendida pelos técnicos do FMI de redução drástica do déficit público, quando o mesmo dependia das taxas esperadas de inflação, haja vista, o caráter generalizado da indexação.

Embora fosse evidente que a supervisão do FMI seria uma condição necessária para o funcionamento do novo esquema de financiamento externo, e que um reescalonamento dos pagamentos era inevitável, a proximidade das eleições gerais (marcadas para 15 de novembro) 
obrigou o governo a adiar o pedido formal de auxílio ao FMI até o final de novembro. A frustração do ajustamento externo, a falta de progresso nas condições internas $\mathrm{e}$ as incertezas quanto às perspectivas futuras da economia desempenharam um papel importante na derrota do partido do governo nas eleições de novembro. A renegociação da dívida externa era a questão predileta dos partidos da oposição durante esta campanha eleitoral, e permaneceu em voga até as eleições presidenciais, dois anos depois. (CARNEIRO \& MODIANO, 1992: 329-330).

Segundo Carneiro \& Modiano (1992) através do Decreto-lei 2012, de janeiro de 1983, o governo tornou sem efeito o adicional de $10 \%$ que incidia sobre a variação semestral do INPC para os assalariados com renda de até três salários mínimos (3SM) e reduziu os coeficientes de repasse na faixa salarial de 3 a 10 salários mínimos (3SM - 10SM). Ainda na tentativa de reduzir a indexação salarial, o governo propôs mais três mudanças na lei salarial ao longo de 1983. A mais ambiciosa destas propostas, o Decreto-lei 2045, que contemplava um coeficiente uniforme de repasse de $80 \%$ da variação semestral do INPC para todas as faixas salariais, não pode se beneficiar do artifício do decurso de prazo para a sua aprovação, pois foi rejeitada pelo Congresso Nacional em fins de outubro. O governo, então, através do Decreto-lei 2065, reduziu mais uma vez os percentuais de correção automática para as faixas entre 3 e 15 salários mínimos (3SM-15SM) e eliminou a livre negociação a partir de 20 salários mínimos (20 SM). Assim, a desindexação salarial e a aceleração inflacionária resultaram numa queda de cerca de $20 \%$ no poder de compra dos salários ao longo do ano de 1983. (CARNEIRO \& MODIANO, 1992, p. 332.). Uma rápida observação da Tabela 1 mostra que o Salário Mínimo Real (SMR) perdeu um terço do seu poder aquisitivo no período em questão.

Desde 1979 que as restrições externas pesavam como chumbo sobre a economia brasileira. Em 1984, finalmente ocorreram sinais de relaxamento no front externo. O excelente desempenho da economia dos Estados Unidos nos dois primeiros trimestres daquele ano foi importante para estimular o crescimento da economia brasileira. Apenas no primeiro semestre de 1984 a exportação de aço do Brasil cresceu em 40\%, parte importante destas exportações eram importações dos norte-americanos. Enfim, a recuperação deu-se, ainda, em 1984 e foi puxada pelas exportações.

Depois de diversos acordos com o FMI e vários "pacotes" sempre reduzindo salários, a interferência da banca internacional chegou ao ponto do Secretário do Tesouro dos Estados Unidos, Donald Regan, afirmar que a salvação do Brasil estava no Congresso Nacional brasileiro aprovar o Decreto-lei 2045. Se o Congresso não executasse este ato patriótico, o "Brazil" quebraria. Esqueceram 
de avisar ao Senhor Donald que o Brasil era (é) grande demais para quebrar.

\section{Tabela 2}

Brasil

Indicadores selecionados

1978-1983

\begin{tabular}{|c|c|c|c|c|c|c|}
\hline Ano & $\begin{array}{c}\text { Taxa } \\
\text { de } \\
\text { juros } \\
\mathbf{( \% )}\end{array}$ & $\begin{array}{c}\text { Dívida } \\
\text { Bruta } \\
\text { (Bilhões } \\
\text { de US\$) } \\
\text { (a) }\end{array}$ & $\begin{array}{c}\text { Dívida Líquida } \\
\text { (Bilhões de US\$) } \\
\text { (b) }\end{array}$ & $\begin{array}{c}\text { Reservas } \\
\text { Cambiais } \\
\text { (Bilhões de US\$) } \\
\text { (a)-(b) }\end{array}$ & $\begin{array}{c}\text { Termos de } \\
\text { Intercâmbio } \\
\text { (\%) }\end{array}$ & $\begin{array}{c}\text { IGP } \\
\text { (\%) }\end{array}$ \\
\hline 1978 & 10,9 & 43,5 & 19,4 & 24,1 & $-14,6$ & 40,5 \\
\hline 1979 & 13,3 & 49,9 & 24,8 & 25,1 & $-7,1$ & 76,8 \\
\hline 1980 & 15,5 & 53,8 & 31,6 & 22,2 & $-17,7$ & 110,2 \\
\hline 1981 & 19,6 & 61,4 & 40,2 & 21,2 & $-15,4$ & 95,2 \\
\hline 1982 & 19,5 & 69,7 & 46,9 & 22,8 & $-1,8$ & 99,7 \\
\hline 1983 & - & 81,3 & 65,7 & 15,6 & $-1,9$ & - \\
\hline
\end{tabular}

Fontes: Batista Jr (1988a); FGV

É preciso entender que o mesmo país que forneceu capital de núcleo orgânico para criar uma barreira protetora contra o comunismo no Japão e na Coréia do Sul não desejava ter um rival do porte do Brasil na América Latina. Fato é que a proposta contida no II PND e as opiniões fortemente nacionalistas do Presidente Ernesto Geisel nunca agradou aos norte-americanos.

Segundo o Subsecretário do Tesouro dos Estados Unidos, Robert McNamar, os países em desenvolvimento deveriam adotar "políticas mais liberais para investimentos externos [...]. Muitos desses governos impõem significativas restrições e condições para investimentos estrangeiros em seus países" ". O Secretário do Tesouro, ou seja, o chefe de Robert McNamar, o Senhor Donald Regan, aquele que vaticinou que o Brasil quebraria sem o DL 2045/83, foi mais longe do que seu subordinado afirmando arrogantemente que:

Ao tornarem mais fáceis e atraentes os investimentos estrangeiros, os governos da América Latina podem avançar bastante na criação dos empregos. [...] é só assegurar (as empresas norte-americanas) bons lucros e sua repatriação, sem terem medo do imperialismo ianque ${ }^{3}$.

\footnotetext{
${ }^{2}$ Folha de São Paulo. Versão Online. Acesso em 20 de dezembro de 2011

${ }^{3}$ Folha de São Paulo. Versão Online. Acesso em 20 de dezembro de 2011.
} 
Como a renda é distribuída funcionalmente entre lucros e salários $(\mathrm{Y}=\mathrm{L}+\mathrm{W})$ e estes últimos estavam brutalmente comprimidos, fica-se com a impressão que o Senhor Donald pensava em trabalho escravo.

A política de ajustamento externo da economia brasileira, conduzida entre os anos de $1981 \mathrm{e}$ 1984 foi exitosa dentro dos parâmetros fixados pela banca internacional. Foram gerados megasuperávits na Balança Comercial e obteve-se um novo equilíbrio na Conta Corrente do Balanço de Pagamentos. É preciso insistir que o modelo de ajuste utilizado pelo FMI foi profundamente recessivo ao ponto de destruir parte da capacidade instalada. A estratégia foi baseada: (a) na redução do investimento público; (b) na redução do mercado interno via destruição de emprego; (c) na compressão da massa salarial; (d) na aceleração das desvalorizações cambiais; e (e) em taxas de juros altas.

Fato é que com todas as pressões da banca internacional, dos representantes do governo dos Estados Unidos e do governo brasileiro, o DL 2045/83 foi derrotado por mobilizações de massa e por uma frente parlamentar que incluía o Partido Trabalhista Brasileiro (PTB), o único Partido aliado do PDS governista.

O desgaste do governo tinha se aprofundado ao extremo e a campanha nacional pelas eleições diretas, denominada de diretas-já tinha conquistado o apoio de quase toda a sociedade brasileira, isto é, empresários, trabalhadores, intelectuais, artistas, religiosos, etc. Duas exceções se erguiam corajosa e fanaticamente: a extrema-direita militar explodindo bombas e parte da grande imprensa, particularmente a Rede Globo que escrevia uma história ficcional e falsificada, onde não havia multidões nas ruas. Onde o comício do Vale do Anhangabaú havia reunido milhares de pessoas ${ }^{4}$, cabendo lembrar, segundo o Jornal Nacional que o governador havia liberado o metrô.

Derrotada a emenda das "diretas-já" por margem pequena de votos, as forças de oposição se articulam para garantir uma vitória no Colégio Eleitoral. A Aliança Democrática consegue $70 \%$ dos votos e elege a chapa Tancredo Neves e José Sarney. A via indireta provoca diversas acomodações. Perde-se o impulso criativo das massas. Surge um momento de consternação e união nacional com o falecimento, antes da posse, do Presidente Tancredo e a assunção ao cargo de Presidente do Brasil do Senador José Sarney.

\footnotetext{
${ }^{4}$ A estimativa mais conservadora dos órgãos que acompanham movimentação de massas, foi a da Polícia Militar de São Paulo, que divulgou o quantitativo de um milhão e meio de pessoas.
} 


\section{O Plano Cruzado e os resultados não esperados.}

Quando se analisa o I Plano Nacional de Desenvolvimento da Nova República (IPND-NR) observa-se a intenção do novo governo de enfrentar alguns dos principais problemas econômicos. $\mathrm{O}$ ponto central do Plano já se explicita no preâmbulo quando se define como projeto de reforma, quando defende o crescimento econômico e o combate à pobreza. Qualquer possibilidade de crescimento sustentado, segundo o I PND, dependia do equacionamento das finanças públicas e do controle inflacionário, que dependem de uma renegociação da dívida externa com redução das transferências reais para o exterior ${ }^{5}$

O problema é que o ano de 1985 é de um lento compasso de espera. A recorrente dualidade da política econômica brasileira e do próprio Estado já estava recolocada mais uma vez. De um lado, no Ministério da Fazenda, Francisco Dornelles defendia uma política monetarista clássica composta por corte nos gastos públicos ${ }^{6}$, contração monetária e restrições de crédito. Enfim, às favas com os anseios da população que ocupou os espaços públicos por democracia. Ás favas os desejos de parte significativa dos empresários, como Albano Franco, Paulo Cunha e Ermírio de Morais, todos paulistas, que queriam a economia acelerando e não o pé pesado, quase morto, no freio.

Se na Fazenda dominava a ortodoxia, no Planejamento, uma equipe chefiada por João Sayad propunha o crescimento e defendia o desenvolvimentismo. Assim, era necessário aumentar a eficiência global do sistema industrial, incorporar tecnologia e expandir o mercado interno, através da recomposição firme do poder de compra dos salários. "Era preciso um padrão de desenvolvimento que orientasse a produção para o atendimento das necessidades básicas da população ${ }^{7}$.

Enquanto o impasse ortodoxia-heterodoxia permanecia, a economia apresentava indícios de desaceleração e recrudescimento inflacionário. A taxa de inflação do trimestre janeiro-março de 1985, quando anualizada, se projetava em uma taxa de quase $300 \% .^{8}$. As tentativas de crescimento esbarravam na política monetária restritiva do Banco Central. Ao Executivo colocava-se a necessidade de fornecer elementos para que um dos exércitos vencesse a guerra. Quando a inflação bateu em 14\%

\footnotetext{
${ }^{5}$ SEPLAN. I Plano Nacional de Desenvolvimento da Nova República

${ }^{6} \mathrm{O}$ déficit público só é fator desencadeante de inflação se a economia estiver operando no pleno emprego. No caso da existência de capacidade ociosa o gasto público opera no sentido de aumentar o nível de atividade sem elevação do nível geral dos preços, inclusive reduzindo pressões inflacionárias pelo lado da oferta. "Tão simples, tão elementar,

${ }^{7}$ SEPLAN. I PND-NR, P. 136

${ }^{8}$ IBGE. Online. Acesso em 15 de novembro de 2011. A taxa anualizada era de 293\%.
} 
em agosto, caiu Dornelles, toda sua equipe da Fazenda e do Banco Central. Vitória dos desenvolvimentistas. Toma posse como Ministro da Fazenda o empresário Dílson Funaro que forma uma equipe com economistas heterodoxos ligados à Unicamp.

O ministro Funaro e sua equipe definem o combate à inflação com manutenção do crescimento econômico. A medida mais importante do período foi a redução da taxa de juros, fato que escandalizou a ortodoxia. O raciocínio era simples: não havia pressão de demanda na economia. Por sua vez a poupança depende da renda e não da taxa de juros, enquanto o investimento depende de taxas de juros baixas. Aumento do crédito e maior melhoria dos salários, "engata" o mercado interno ao estímulo vindo do setor externo, mas que já perdia força. Contudo, apesar do esforço do governo, a inflação não cedia. Era desejável um plano de combate à inflação que tivesse uma lógica mais abrangente.

Como dito acima, necessária se fazia uma ação mais robusta contra a inflação. "Assim, podese dizer que o ano de 1985 terminou - melancolicamente para o governo e para a maioria da população - com uma forte aceleração inflacionária"9. A medida para o mês de dezembro acusou $13,20 \%$ e para o ano de 1985, 235,11\%. O governo do Presidente José Sarney precisava urgentemente estancar a elevação dos preços, para tanto foi instituído em 28 de fevereiro de 1986 um plano de estabilização não recessivo, denominado de Programa de Estabilização Econômica ou Plano Cruzado.

A medida mais controversa do Plano Cruzado, por chocar frontalmente com a lógica dos mercados capitalistas, foi o congelamento de preços. Apesar de combatida, principalmente no campo dos princípios que regem o funcionamento do capitalismo, aquela foi a medida mais eficaz e efetiva de todas. A queda abrupta da inflação de 14,98\% em fevereiro para 5,5\% em março e - 0,58\% ${ }^{10} \mathrm{em}$ abril. Este movimento de descenso do nível geral de preços levou a um grande apoio popular ao Plano e ao Presidente.

Antes de discutir as medidas implementadas pelo Plano Cruzado, em particular o congelamento dos preços, é importante destacar as condições e as políticas macroeconômicas que facilitaram o êxito daquele:

(a) elevação dos níveis de confiança da população nas intenções do governo;

(b) recuperação da capacidade de realização de políticas macroeconômicas, dada o rompimento com o FMI;

\footnotetext{
${ }^{9}$ FSP, 02/03/1986.

${ }^{10}$ Todos os dados desta seção foram recolhidos do IBGE, exceto quando dito em contrário.
} 
(c) acumulação de reservas cambiais que poderiam ser usadas em caso de desabastecimento;

(d) existência de uma importante folga cambial, pois de fevereiro de 1983 ao mesmo mês de 1986 acumulou-se uma desvalorização efetiva e real de 37\%, o que permitiu o congelamento do câmbio;

(e) melhoria das finanças públicas pela queda na taxa de juros e pelo aumento da receita tributária como função positiva da renda;

(f) criação da Secretaria do Tesouro Nacional e unificação dos orçamentos fiscal e monetário.

Para entender o congelamento de preços e as reações populares em favor do mesmo, ou seja, para entender a economia moral do Cruzado, é preciso compreender que inflação foi, é, e será sempre um problema de conflito distributivo. Sabendo-se que a elevação dos preços é um fenômeno que resulta de um conflito entre as classes sociais e entre segmentos de uma mesma classe, é fácil deduzir que quanto maior for o nível de pressão dos agrupamentos sociais sobre a renda gerada, maior a expansão dos preços e maior a luta distributiva pela renda e pelo produto real criado. No Brasil das décadas de sessenta, setenta e parte dos oitenta do século passado, viveu-se em um regime autoritário que arbitrava o conflito distributivo pela força.

A questão principal é que o Plano Cruzado significou uma inversão fortíssima nos mecanismos de mediação e controle do conflito que operava até fevereiro de 1986. A abertura política, o aumento da organização dos trabalhadores, principalmente dos metalúrgicos, petroleiros e bancários ao lado da redemocratização tornou obsoleto o arcabouço institucional que administrava a luta econômica das classes sociais. O Plano Cruzado, e em particular o congelamento de preços foram aceitos e defendidos pela população porque realizou uma nova configuração de rendas no país e que durou aproximadamente seis meses. Ou de acordo com os argumentos de Camargo e Ramos:

Até fevereiro de 1986, os trabalhadores e setores mais competitivos da economia foram os que assimilaram a maior parte dos custos do ajuste externo, o que era obtido através de acelerações inflacionárias crescentes. Com adoção da escala móvel, os salários reais permaneciam constantes ou cresciam, exceto em conjunturas com taxas de inflação extremamente elevadas. Em outras palavras, o aumento de preços deixou de ser um mecanismo de redução dos salários reais. Por outro lado, o setor externo, os setores mais oligopolizados, e o setor financeiro, que, antes do Plano, eram os que se beneficiavam com as acelerações inflacionárias, após sua implementação passaram a ser os principais perdedores na luta 
distributiva, caso a inflação persistisse. (CAMARGO \& RAMOS, 1988: 29).

Segundo o economista Francisco Lopes, em entrevista concedida a José Onofre da Folha de São Paulo ${ }^{11}$ o governo já havia adquirido a força para garantir o sucesso do Plano: a participação voluntária dos consumidores, nos pontos de venda e na vigilância do congelamento. Para Lopes "os opositores são os que não entenderam e os que ganhavam com a inflação alta". Apesar do otimismo exagerado do economista e do menosprezo quanto a possíveis reações dos empresários capitalistas, havia muita verdade nas suas palavras, a saber, só estava contra a estabilização quem perdia com ela e quem não a entendia no sentido de não admitir interferências no mercado que não fossem em beneficio próprio. Estava a favor aqueles que começavam a ganhar alguma renda e que sabia que a derrota do plano significava uma volta a situação anterior. Ou seja, o conflito distributivo adquiriu nova identidade, e se expressava pelo apoio ou o repúdio ao congelamento.

Henry Maksoud, destacado representante de um segmento da burguesia brasileira, num artigo intitulado "Por que discordo do pacote" 12 , depois de afirmar que sempre havia criticado os pacotes econômicos e atos de intervenção no mercado, assim se posiciona quanto ao Plano Cruzado:

Ao ser divulgado o "decreto-lei da inflação zero" logo notei que nada havia mudado no enfoque substantivo dado à inflação, mas percebi de imediato como seria muitíssimo mais iníqua e abrangente que antes a intrusão governamental na vida, na liberdade e na propriedade das pessoas. Por uma questão de coerência, de princípios,.não de dogmas, e para estar em paz com a consciência, tive que me postar outra vez na difícil posição de quem diverge da opinião geral. Apesar da extasiante aceitação popular, do patrulhamento ideológico que emergiu (que supostamente não existiria na "democracia" da Nova República) e da absurda violência, estimulada pela propaganda nos meios de comunicação, sou dissente em relação a este plano por muitas razões concretas. (FSP, 24/04/1986).

Analisando o discurso do Senhor Maksoud, percebem-se claramente as seguintes questões: (a) o articulista é contrário a intervenção do Estado, mas na verdade ele é contra aquela que possa

\footnotetext{
${ }^{11}$ Folha de São Paulo, 02/03/1986.

12 FSP, 24/04/1986

${ }^{13}$ Nome propagandístico dado ao Plano Cruzado
} 
beneficiar os de baixo, pois no Brasil como em todos os países capitalistas, o Estado foi um parceiro constante e fiel da burguesia, inclusive em atos pouco recomendáveis; (b) apesar do verniz civilizado do Senhor Maksoud, na essência seu ódio de classe é o mesmo dos antigos Senhores Coloniais; (c) por fim, acusar os defensores do plano de patrulhamento ideológico e as mobilizações populares, mesmo desorganizadas, mas legítimas e necessárias, como atos de violência, é, no mínimo um disparate.

Paul Singer, renomado economista de esquerda e fundador do Partido dos Trabalhadores, também se colocou contra o Plano. Claro que as razões de Singer diferem das apresentadas por Maksoud e outros representantes das elites nacionais. Singer argumenta que o plano consistiu em uma operação radical, onde o governo conseguiu de um só golpe desatar o nó inflacionário, quando deveria fazê-lo pacientemente, identificando e regulando os diversos conflitos distributivos. Assim, a imobilização dos preços permitiu uma trégua nos conflitos, de forma que com o aumento significativo do consumo, a renda aumentou de forma a permitir uma maior participação de vários segmentos sem que os outros sofressem perdas.

Para Singer, havia fragilidade no congelamento e o entusiasmo dos fiscais de Sarney era fogo de rápida combustão, além do que os fiscais eram impotentes diante da força do capital. Pouco podia a população contra os açambarcadores de mercadorias, os remarcadores de preços e a venda com ágio. Assim, diz o autor, o governo deveria ter aproveitado a trégua para fazer uma autentica e sistemática redistribuição efetiva de renda.

Começando pelo fim, a questão era de como um governo fraco e atacado por todos os lados pelas classes sociais em combate, poderia fazer uma redistribuição ordenada de renda? $\mathrm{Na}$ verdade isto só seria possível atacando os interesses do capital em suas diversas formas, porém tratava-se principalmente de enfrentar os interesses dos principais beneficiários de sempre: o setor externo, os setores oligopolizados, e o setor financeiro. Dito de outra forma era lutar contra o conjunto da burguesia que detém, no Brasil, a maior fatia de poder econômico e político. Infelizmente, Singer nunca ensinou a fórmula mágica. Só um governo de esquerda, programaticamente definido pelo socialismo ou por um Governo de transição dos trabalhadores da cidade e do campo, poderia fazê-lo. O governo Sarney não era nem nunca disse ser este governo. O partido que dizia ser, e que Singer, juntamente com tantos intelectuais engajados fundou, ao chegar ao poder, não deu ouvidos ao que aquele economista propôs em 1987. 


\section{O Pós-Cruzado e o último Sarney}

O Plano Cruzado foi uma "engenharia" brilhante para desmontar o processo auto- alimentador da inflação, contudo o controle inflacionário, ainda não é a derrota completa da inflação. Inflação faz "metástase" quando as causas primárias permanecem ativas. O período de congelamento deveria ter sido usado para um ajustamento estrutural, inclusive porque a economia já crescia por três anos seguidos sem grandes "pacotes" de investimentos que aumentasse a capacidade produtiva. Com o esgotamento da capacidade ociosa os problemas de pressão de demanda, que os economistas ortodoxos enxergam em qualquer situação, poderiam se tornar realidade. A taxa de investimento havia caído para $17-18 \%{ }^{14}$

Enquanto os monetaristas continuavam argumentando que independente da ocupação da capacidade instalada e do tamanho das encomendas de investimentos, o problema era de demanda e estava associado ao déficit público; os keynesianos afirmavam que o problema era a dívida externa que ao absorver parte significativa do PIB comprometia o combate à inflação e às políticas de investimentos e crescimento econômico.

Em março de 1986 em uma reunião entre o governo brasileiro, banqueiros norte- americanos e técnicos do BID (Banco Interamericano de Desenvolvimento), o ministro João Sayad repetiu um trecho do I PND-NR, onde o compromisso era firmado com a nação e não com a banca internacional:

Para garantir simultaneamente o combate à inflação e o crescimento econômico, o governo brasileiro entende, contudo, ser indispensável resolver em caráter definitivo, o problema da dívida externa [...] a redução da excessiva transferência de recursos para o exterior constitui elemento indispensável à consolidação do equilíbrio financeiro do setor público, à retomada dos investimentos e, portanto, à sustentação do crescimento no médio e longo prazos. (I PND-NR, 1985, p. 62).

Segundo Solnik (1987) a moratória da dívida sempre esteve presente como hipótese de trabalho, não apenas dos economistas, mais do próprio Presidente Sarney. Para o ministro Sayad, o momento adequado teria sido o dia do decreto do Cruzado, ou seja, 28 de fevereiro:

Eu achava, e ainda acho, que a moratória é um instrumento de

\footnotetext{
${ }^{14}$ A taxa de investimento que foi na média de $27,0 \%$ do PIB nos anos setenta despencou para a faixa de $16,0 \%$ no período de 1982-1985 e elevou-se para 17,7\% em 1986. Os dados são do IBGE.
} 
negociação. Hoje eu vejo com clareza que no dia 28 de fevereiro de 1986, quando a gente tinha 8 bilhões de dólares de reservas, naquele momento a gente deveria ter suspendido os pagamentos. (SOLNIK, 1987: 110).

Em diversas oportunidades, a questão da moratória soberana voltou a ser cogitada, mas não foi efetivada. Alguns membros do governo consideravam-na muito radical, outros acreditavam nas boas intenções da banca, em particular, nas promessas do Presidente da Reserva Federal dos Estados Unidos, Paul Volker. É hora de pensar em voz alta: quem é ingênuo quando se defronta com os poderosos, o povo ou suas elites?

Fato é que a inflação voltou. No começo a forma fenomênica era o desabastecimento, depois a elevação dos preços: $0,32 \%$ em maio, $0,53 \%$ em junho, 0,63\% em julho e 1,33\% em agosto ${ }^{15}$. O aquecimento da demanda faz aumentar a absorção interna de produtos que antes estavam sendo exportados, além de promover aumento das importações. Resultado: piora da Balança Comercial e queima das reservas cambiais.

No front político é preciso compreender que muitas decisões deixaram de ser tomadas ou foram proteladas para garantir a vitória do $\mathrm{PMDB}$, que era o partido hegemônico do governo. O próprio congelamento dos preços só se justifica por tanto tempo porque era a medida mais efetiva e mais popular do Plano. O uso político do Cruzado se tornou evidente quando nas eleições gerais de 15 de novembro de 1986, o PMDB fez todos os governadores com exceção do estado de Sergipe. Fez mais de $50 \%$ da Câmara Federal e 77\% do Senado. É fundamental lembrar-se que não se tratava de um Congresso Nacional normal, mas de um Congresso com atribuições de Assembléia Nacional Constituinte. ${ }^{16}$

Menos de uma semana depois das eleições, isto é, no dia 21 de novembro, o governo lança o Cruzado II, que foi de fato um anti-Cruzado ${ }^{17}$. Em uma "canetada" do governo jogou-se fora toda uma experiência de ajustamento não-recessivo com crescimento econômico, distribuição de renda e mobilização popular.

\footnotetext{
${ }^{15}$ IGP-DI da Fundação Getúlio Vargas. FGV - Online. Acesso em 26 de novembro de 2011.

${ }^{16}$ Folha de São Paulo, 16 de novembro de 1986.

${ }^{17}$ Saint-Exupery no Pequeno Príncipe trabalha de forma brilhante com a relação entre aparência, essência e representação. Há um desenho que para qualquer humano adulto é de um chapéu, mas que para a criança representa "uma jibóia que engoliu um elefante". Foucault, também, trabalha a idéia com a imagem de um cachimbo com a legenda: "isto não é um cachimbo". O Cruzado II, talvez, merecesse a legenda: "isto não é um Cruzado
} 
O problema do Cruzado II não era de diagnóstico. Desde setembro, pelo menos, já havia um quadro de excesso de demanda. Este diagnóstico unia, temporariamente, ortodoxos e heterodoxos, o Ministério da Fazenda e o Ministério do Planejamento. Havia, inclusive, concordância na prescrição: aumento dos impostos como mecanismo de redução da inflação e do crescimento. Além dos efeitos sobre a inflação, o choque tributário reduziria a absorção interna, aumentaria as exportações e diminuiria as importações, recompondo a Balança Comercial.

A divergência era sobre qual o imposto deveria ser o vetor. O Planejamento defendia o uso do Imposto de Renda que incidiria sobre a riqueza monetária e não teria nenhum impacto sobre os preços da economia. A Fazenda elegeu o IPI de cinco produtos ${ }^{18}$ selecionados sob o argumento de maior dispersão sobre um universo maior de contribuintes e arrecadação maior e mais rápida. É claro que o aumento do IPI é sempre repassado para os $\operatorname{preços}^{19}$, o que per si é inflacionário. Os técnicos da Fazenda propuseram que os aumentos fossem expurgados dos índices de preço. Venceu o Ministério da Fazenda, perdeu o Ministério do Planejamento. Ganhou o Ministério dos fundamentos neoclássicos, perdeu o Ministério do Crescimento Econômico ${ }^{20}$.

$\mathrm{O}$ discurso das finanças sadias estava de volta. $\mathrm{O}$ retorno da inflação, a moratória tardia ${ }^{21}$, a queda na taxa de $\operatorname{lucros}^{22}$, criaram as condições adequadas para mais um “arquivamento" das propostas desenvolvimentistas. Sayad não esperou para ver e pediu demissão em 17 de março. Funaro esperou até 20 de abril, depois que a nata do capitalismo brasileiro, representada pelos 24 maiores empresários do país pediu sua cabeça. A lógica é elementar: é possível agüentar "os de baixo" fechando supermercados, mas é insuportável a queda na taxa de lucros.

${ }^{18}$ Foram os seguintes produtos e as correspondentes majorações: gasolina (60\%), telefonia e eletricidade (120\%), bebidas (100\%), automóveis (80\%) e cigarros (45\% a 100\%). Fonte: Ministério da Fazenda - Online. Acesso em 15 de outubro de 2011 .

19 O IPI e o ICMS são impostos altamente contaminadores de preços, porque independente do tamanho da empresa, o repasse é automático. Exemplo: um vendedor de água de coco em qualquer praia, paga frete para colocar seu produto no ponto de venda, um aumento do IPI sobre combustíveis, certamente, aumentará o preço do coco.

${ }^{20} \mathrm{O}$ termo foi cunhado pelo Professor e Ministro João Sayad. Utiliza-se, aqui, no mesmo sentido, ou seja, “o Ministério da Fazenda que faça política restritiva, que corte gastos, o Planejamento vai estimular a atividade econômica, os investimentos e o emprego"

${ }^{21} \mathrm{Na}$ década de oitenta, o Brasil pagou de juros da dívida externa, o montante de 150 bilhões de dólares americanos. Quando o Presidente José Sarney decretou a moratória, as reservas cambiais brasileiras eram de 2,8 bilhões de dólares. Fonte: IBGE - Online. Acesso em 19 de novembro de 2011.

${ }^{22}$ Entre 1984 e 1986 a Rentabilidade sobre o Patrimônio ficou na média de 13\%, mas caiu para 6,3\% em 1987. Fonte: Exame. "Melhores e Maiores", julho, 2002, p. 22. 
Na vacância do ministro Funaro assume o Professor Luiz Carlos Bresser Pereira. Em 12 de junho, Bresser Pereira lançou o chamado Plano Bresser que congelou salários e preços por três meses. Novamente a sociedade teve mais do mesmo, ou seja, garroteamento da demanda via corte nos gastos públicos, arrocho salarial e aumento nos juros. O Plano deu errado. O Salário Mínimo Real caiu 18,5\% em relação ao ano anterior, porém a rentabilidade do capital, como visto acima, caiu de 13,3\% para $6,3 \%$. O PIB cresceu apenas 2,9\%. A dose de ortodoxia foi cavalar e quase mata o paciente. A taxa de lucro caiu porque ocorreu queda no consumo e queda na confiança dos empresários.

Com a demissão de Luiz Carlos Bresser Pereira assume a Pasta da Fazenda o economista Maílson da Nóbrega. O novo ministro defende o retorno ao FMI, suspensão imediata da Moratória, cortes nos gastos públicos, aumento dos juros reais e confisco salarial. Nóbrega resolve denominar sua política de "feijão-com-arroz". Nunca o prato mais popular (e mais nutritivo) do país foi tão indigesto. Nunca, na história republicana brasileira, um ministro da Fazenda foi tão "apagado" publicamente, mas cumpriu um grande papel em defesa dos interesses do capital financeiro e contra os interesses nacionais. Nunca um governo central no Brasil, cumprindo todo seu mandato, teve um fim tão melancólico do que o último Sarney.

No dia 14 de janeiro de 1989 o ministro Má́lson da Nóbrega resolve mudar de prato. Sai do “feijão-com-arroz” e lança um “baião-de-dois recessivo" denominada de Plano Verão e formada pelas seguintes medidas ${ }^{23}$ :

(a) manutenção da política de juros altos;

(b) novos cortes nos gastos públicos;

(c) congelamento dos preços com alinhamento prévio nos preços de vários produtos ${ }^{24}$;

(d) conversão dos salários pela média real dos últimos doze meses, incorporando a URP (Unidade Referencial de Preços) prevista para janeiro;

(e) extinção da URP a partir de fevereiro, com a instituição da "livre negociação";

(f) instituição de nova moeda, o cruzado novo (NCZ\$) correspondendo a mil cruzados.

\footnotetext{
${ }^{23}$ Modiano, 1992, pp. 347-386.

${ }^{24}$ Leite (47,5\%); pão (33,3\%); tarifas telefônicas (35,0\%); tarifas postais (63,5\%); eletricidade (14,8\%); gasolina (19,9\%); álcool (30,5\%). Fonte: Ministério da Fazenda - Online. Acesso em 10 de novembro de 2011.
} 
O resultado não podia ser pior. A inflação entrou em descontrole total rumo a uma hiperinflação aberta, mesmo com os mecanismos de indexação e correção monetária dos balanços. Projetou-se um índice geral de preços de $1.764 \%{ }^{25}$ para 1989 . O lado mais cruel dos desacertos promovidos pela ortodoxia chegou rápido: estagnação e desemprego, ou seja, a estagflação.

Todas as ações de privatização desencadeadas no governo do Presidente José Sarney foram aceleradas pela equipe de Maílson da Nóbrega. Tanto no Plano Verão quanto no pouco conhecido Plano de Emergência ${ }^{26}$ (agosto de 1989) listou-se um amplo conjunto de empresas que deveriam ser privatizadas. Claro que não havia mais tempo, nem correlação de poder político capaz de realizar a venda de empresas como a Açominas, mas o ministro deixava um mapa completo da futura privataria.

Apesar de concordar-se com a caracterização dos anos oitenta como a década perdida, dado o baixo nível do crescimento e os desequilíbrios inflacionários e das contas externas, é, também, correto considerá-la como uma década ganha pelo nível de experimentação de propostas de políticas econômicas e pela participação popular nos destinos do país.

\footnotetext{
25 Modiano, 1992, pp. 347-386.

${ }^{26}$ Fonte: Projeto Abertura de Capital/Conselho Federal de Desestatização.
} 


\section{Capítulo 2}

\section{Os anos noventa: a "década mais que perdida"}

\section{A ideologia neoliberal e a reconstrução hegemônica.}

Após a Segunda Guerra Mundial e até o início dos anos setenta, o capitalismo cresceu a taxas altíssimas, a ponto de alguns estudiosos começarem a falar de um capitalismo sem crise, ou seja, a esperança de Adam Smith num capitalismo redentor de toda humanidade havia finalmente chegado, apesar da existência de um sistema antagônico (o socialismo burocrático) também estar obtendo grandes resultados no front econômico.

Este período ficou conhecido, eufemisticamente, de "anos dourados". Porém, a crise do “capitalismo sem crise" instala-se em 1973 numa combinação explosiva de queda na taxa de expansão do produto com altas taxas de inflação. Segundo Anderson (1996) foi a partir daquele momento de crise do sistema capitalista que a ideologia neoliberal ganhou alento. O discurso dos defensores do mercado absoluto afirmava que os problemas do capitalismo não estavam no sistema capitalista, mas no poder excessivo dos sindicatos e no próprio movimento dos trabalhadores que haviam destruído as bases naturais da acumulação de capital com pressões econômicas descabidas de aumentos salariais e pressões políticas que aumentavam os gastos sociais do Estado. Tais pressões, de acordo com a doutrina liberal, destruíram as margens necessárias e sadias dos lucros.

Para o quadro apresentado acima a solução seria, não um Estado fraco como muitos supõem, mas um Estado forte capaz de enfrentar e derrotar o poder sindical e de desenvolver políticas que aprofundam o desemprego e a precarização do mundo do trabalho e que retire direitos sociais consagrados, desamparando ainda mais os trabalhadores. Contudo, o Estado deveria ser forte também na condução e no controle da moeda ${ }^{27}$, utilizando-a como instrumento de redistribuição de renda para os mais ricos, dado que a desigualdade seria uma condição necessária para o crescimento econômico,

\footnotetext{
${ }^{27}$ A moeda é o instrumento essencial da violência capitalista e o Estado é o detentor da violência legítima. É a moeda que define quem compra e quem não compra as mercadorias que estão no mercado. É a moeda por corporificar o valor e, portanto a riqueza produzida, quem define os estratos de renda, e permite em que nível, ou simplesmente não permite acesso às mercadorias. A moeda é o mecanismo básico de violência estatal ao estratificar e manter estratificada a sociedade, isto é, a de garantir que a sociedade permaneça dividida em classes sociais e em segmentos de renda. Fonte: AGLIETA \& ORLEANS (1990)
} 
ou seja, o capitalismo só seria possível com suas assimetrias naturais ${ }^{28}$.

A mensagem dos neoliberais históricos era extremamente dura, mas completamente de acordo com a lógica interna do capitalismo, mas só era dita de forma agressiva e aberta pelos neoliberais fundamentalistas como Hayek. A grande maioria dos neoliberais (inclusive os nativos) não tinha a coragem e a honestidade de esclarecer suas reais intenções, desvendando, assim, sua própria ideologia. A primeira experiência neoliberal de acordo com Anderson (1996) ocorreu no Chile sob o comando do economista Milton Friedman na ditadura de Pinochet. Naquele país foram implantados rígidos programas de desregulação, desemprego massivo, repressão sindical, privatização de bens públicos e uma decorrente redistribuição de renda em favor das classes mais ricas.

Note-se que o uso de uma ditadura como o Chile de Pinochet, onde todos dispositivos de direitos democráticos estavam suspensos, mostra que a democracia não é um valor fundamental para os neoliberais. Anderson (1996) argumenta que Hayek ensinava que a liberdade e a democracia poderiam tornar-se incompatíveis, se a maioria democrática decidisse limitar os direitos incondicionais de cada agente econômico de dispor de sua renda e de sua propriedade. A conclusão que se deve chegar a partir dos argumentos hayekianos é de que neste caso deve-se suprimir a democracia em defesa da liberdade dos mercados absolutos.

A doutrina neoliberal além de sua natureza regressiva e do seu ódio de classe aos pobres coloca como necessário a destruição do sindicalismo, a compressão dos salários, o aumento do desemprego e a elevação dos lucros, origem da acumulação do capital, e a esse conjunto de medidas e de objetivos, o neoliberalismo chama de recuperação econômica, ou seja, a ideologia neoliberal defende que estas medidas são meios para a completa recuperação de um capitalismo com altas e estáveis taxas de crescimento.

É, entretanto, nesse objetivo final que o neoliberalismo falha completamente, pois exceto casos isolados e temporários, o capitalismo não consegue apresentar altas taxas de crescimento, muito menos consegue sonhar com uma recuperação do forte crescimento verificado nos trinta anos dourados do pós-guerra, sob o comando do keynesianismo e do Estado do bem-estar social.

\footnotetext{
${ }^{28}$ Os argumentos de Marx em O Capital são no sentido de mostrar que a natureza essencial do capitalismo é: (a) uma sociedade dividida em classes sociais, sendo duas fundamentais, os capitalistas e os trabalhadores; (b) uma minoria da sociedade capitalista (os capitalistas) possui e controla todos os meios de produção e quase toda riqueza social, enquanto a maioria social possui apenas sua capacidade de trabalho; e (c) as desigualdades refletem as próprias leis de funcionamento desse sistema. A tese marxista da crescente pauperização da classe trabalhadora continua perfeitamente atual, desde que aplicada de forma relativa, isto é, a pobreza aumenta na periferia do sistema e em regiões periféricas internas do capitalismo central.
} 


\section{A disputa dos dois projetos para o Brasil nos noventa: vitória da alternativa neoliberal e Governo Collor}

O segundo semestre de 1989 transcorre sob o signo de um campo de forças bastante complexo. No front externo uma proposta estratégica de reordenamento do capitalismo mundial expresso em quatro pilares: abertura econômica; desestatização; desregulamentação do capital e flexibilização do trabalho. O significado prático era de que os países deveriam suspender barreiras protecionistas, facilitando um amplo comércio entre si; privatizar suas ineficientes empresas estatais; permitir total mobilidade aos capitais e reduzir a um "mínimo de decência" 29 os direitos sociais dos trabalhadores. Claro que estas medidas duras deveriam ser implementadas, onde mais necessárias fossem, ou seja, na zona de influência norte-americana (a América Latina). Estas idéias são fundamentos do neoliberalismo e estão sintetizados no "Consenso de Washington". Na verdade, o objetivo implícito era de abrir mercados para as mercadorias e capitais dos países centrais. Novamente havia capitais excedentários. Novamente o capital estava congestionado no núcleo orgânico do capitalismo.

No front interno estava-se no apagar das luzes de um governo que teve duas faces. No primeiro momento tentou uma estratégia de ajuste não-recessivo com mobilização popular, em um segundo tempo fez uma política recessiva, denominada de feijão-com-arroz associada às primeiras privatizações.

Ainda no campo interno, duas alternativas se apresentaram disputando o voto popular. De um lado um conjunto de forças de esquerda em torno da candidatura de Luiz Inácio Lula da Silva. Do outro um conjunto de forças de direita em torno da candidatura de Fernando Collor de Mello, com amplo apoio das classes dominantes e da grande imprensa. Venceu a segunda configuração de forças que enfeixavam a reconstrução hegemônica do "Consenso de Washington" e do neoliberalismo.

A posse do Presidente Fernando Collor ensejou um Plano de Estabilização para a caótica economia brasileira. O grande problema para o novo governo central era que havia rejeição social tanto às políticas ortodoxas, quanto às heterodoxias dos congelamentos. Segundo Faro (1990) o Plano Collor I, de março de 1990, tinha forte tendência recessiva e combinava o confisco dos ativos financeiros, incluindo a poupança, com prefixação da correção dos preços e salários, além do câmbio

\footnotetext{
${ }^{29}$ O conceito de "mínimo de decência" de direitos diz respeito a um conjunto irredutível de garantias sem o qual os trabalhadores estariam completamente a mercê dos empregadores, inclusive para exploração do trabalho escravo. Este se deriva do conceito de trabalho decente utilizado pela Organização Internacional do Trabalho (OIT).
} 
flutuante e uma reforma administrativa com fechamento de órgãos públicos e demissões de funcionários.

A medida efetiva de combate à inflação foi o confisco dos ativos financeiros e a retirada de $80 \%$ do meio circulante. Com tal política a inflação cai porque a demanda cai, independente da inflação ser de demanda, independentemente da economia operar ou não com capacidade ociosa. O brutal enxugamento da liquidez simplesmente deixou parte significativa da oferta sem valor, pois faltava poder real de demanda (renda disponível). Atingiu-se duramente a poupança popular, fonte de gastos importantes para a economia. Cortou-se, de um golpe, o capital de giro das pequenas e médias empresas. A maioria dessas firmas quebrou. Tudo muito semelhante aquela conhecida piada médica: “a cirurgia foi um sucesso, infelizmente, o paciente veio a óbito”.

Como no Brasil tudo que é velho precisa receber o rótulo de novo para possuir credibilidade, além de uma nova política industrial, houve uma nova política salarial. Esta negou a incorporação legitima de 10,25\% ao salário de março, impediu as categorias com data- base em março de receber a diferença entre a inflação acumulada e os reajustes do período, converteu o salário com base no menor valor de compra, estabeleceu uma prefixação trimestral de salários de modo que futuras perdas salariais seriam resolvidas pela "livre negociação". Com taxas de desemprego de 10\% e um violento ataque ideológico e político aos sindicatos, soava irônico falar em livre negociação entre o capital e o trabalho. Segundo o Dieese/Seade o rendimento médio real na Grande São Paulo caiu em 35\% nos trinta meses do governo Collor de Mello. Isto representa um violento "freio" no mercado interno.

Tabela 3

São Paulo e Brasil

Desemprego e Inflação (\%)

1989-1992

\begin{tabular}{|c|c|c|}
\hline Ano & $\begin{array}{c}\text { Taxa de desemprego na Grande } \\
\text { São Paulo }\end{array}$ & Inflação medida pelo IGP \\
\hline $\mathbf{1 9 8 9}$ & 8,8 & 1782,9 \\
\hline $\mathbf{1 9 9 0}$ & 10,0 & 1476,6 \\
\hline $\mathbf{1 9 9 1}$ & 11,6 & 480,2 \\
\hline $\mathbf{1 9 9 2}$ & 14,9 & 1157,9 \\
\hline
\end{tabular}

Fontes: Dieese/Seade e FGV/Conjuntura Econômica.

Mais uma vez a inflação brasileira desrespeitou os manuais norte-americanos de macroeconomia. Ocorreu queda na demanda, queda acentuada na produção, elevação no volume de 
desemprego e a inflação, quando muito cedeu um pouco, para logo após recrudescer.

O Plano Collor II foi baixado em janeiro de 1991, em um contexto de forte descontrole inflacionário. Tratou-se de uma combinação de congelamento de salários com mais medidas de contração fiscal e monetária.

Dentro da polêmica sobre as vantagens e desvantagens da industrialização substitutiva de importações ${ }^{30}$, o governo lança o que ficou conhecido como a Nova Política Industrial, cujo principal objetivo era de aumentar a eficiência produtiva e comercial de bens e serviços, baseando-se na modernização e reestruturação industrial. Tomando como referência Guimarães (1995) tem-se os seguintes eixos estratégicos:

(a) redução dos níveis de proteção tarifária, eliminação da distribuição indiscriminada e não transparente de incentivos e subsídios, e fortalecimento dos mecanismos de concorrência;

(b) reestruturação competitiva da indústria mediante a adoção de mecanismos de coordenação, de instrumentos de apoio creditício e de fortalecimento da infra-estrutura tecnológica;

(c) fortalecimento de segmentos potencialmente competitivos e desenvolvimento de novos setores, por meio de maior especialização da produção;

(d) maior exposição da indústria brasileira à competição internacional, objetivando inserção no mercado externo, melhora de qualidade e preço no mercado interno e aumento da competição em setores oligopolizados.

Do ponto de vista do desenvolvimento econômico um dos elementos fundamentais é o tamanho do Investimento Direto Estrangeiro (IDE). De 1990 para 1992 o IDE aumentou de 1,2\% no conjunto do investimento para 2,9\%. Um aumento irrisório. Em adição, a participação das empresas estrangeiras aumentou de 41,2\% em 1989 para 42,9\% em 1992, medido pelas vendas, um aumento igualmente irrisório. (Exame, "Melhores e Maiores", julho de 2003). O fato é que o capital não aposta suas fichas em economias em processo recessivo. Por sua vez, como este trabalho já mostrou diversas vezes, a América Latina em geral e o Brasil em particular não representam nenhuma prioridade estratégica para o principal país do núcleo orgânico do capitalismo, ou seja, os Estados Unidos não estão obrigados por razões geopolíticas, ou mesmo puramente econômicas, de fornecer ao Brasil o mesmo tratamento reservado ao Japão, além do que, nesta quadra histórica, o comunismo já não era uma

\footnotetext{
${ }^{30}$ Uma boa discussão a respeito poderá ser encontrada em SUNKEL \& GRIFFITH-JONES (1990).
} 
ameaça real.

\section{Plano Real e Governo Fernando Henrique Cardoso: estabilização com alto desemprego e baixo crescimento.}

Em 1993, ainda no governo de Itamar Franco ${ }^{31}$, o ministro da Fazenda, Fernando Henrique Cardoso, implementou um Plano de Estabilização que ficou conhecido como Plano Real. Na verdade, o governo do Presidente Fernando Henrique começou um ano e meio antes da posse legal, pois no comando do Plano Real e na consecução de políticas alinhadas com o "Consenso de Washington”. De modo que o referido mandatário exerceu o poder por um longo período de dez anos.

O Plano Real foi concebido e implementado em três fases efetivamente encadeadas:

(a) estabelecimento do equilíbrio nas contas do setor público, como forma de eliminar a principal causa da inflação;

(b) criação de um padrão estável de valor, a Unidade Real de Valor (URV);

(c) emissão de uma moeda com poder de compra estável, o real.

Quando os dados são analisados, é incontestável a piora do Brasil após os dez anos do governo de Fernando Henrique Cardoso: maiores taxas de desemprego de toda a história do país, crescimento econômico insignificante, queda constante do rendimento médio dos assalariados (rendimento real), elevação da dívida externa e aumento assombroso da dívida interna, o que levou a uma piora das condições de vida da maior parte da população brasileira e ao aumento da vulnerabilidade externa. Na verdade, o governo priorizou como meta única a política econômica de ajuste, oferecendo taxas de juros altíssimas ao capital financeiro, tanto o nacional quanto o internacional, conseqüentemente, políticas sociais, como saúde, educação, habitação, transporte, saneamento, investimento e industrialização, foram penalizadas pela dependência aos interesses dos grandes "investidores financeiros". O investimento produtivo não encontrou ambiente adequado para sua expansão. As taxas de juros praticadas estiveram sempre acima da Eficiência Marginal do Capital. A lógica especulativa se impôs tudo isso aliado a ausência de uma política industrial levou o país a uma estagnação prolongada.

\footnotetext{
31 A crise econômica e o isolamento do Presidente Fernando Collor levaram ao seu impedimento. Em seu lugar, obedecendo-se a Constituição, assume o Vice Itamar Franco em 02 de outubro de 1992.
} 


\section{Gráfico 1}

Brasil

PIB Real e PIB Per Capita - Variação Percentual

1994-2001

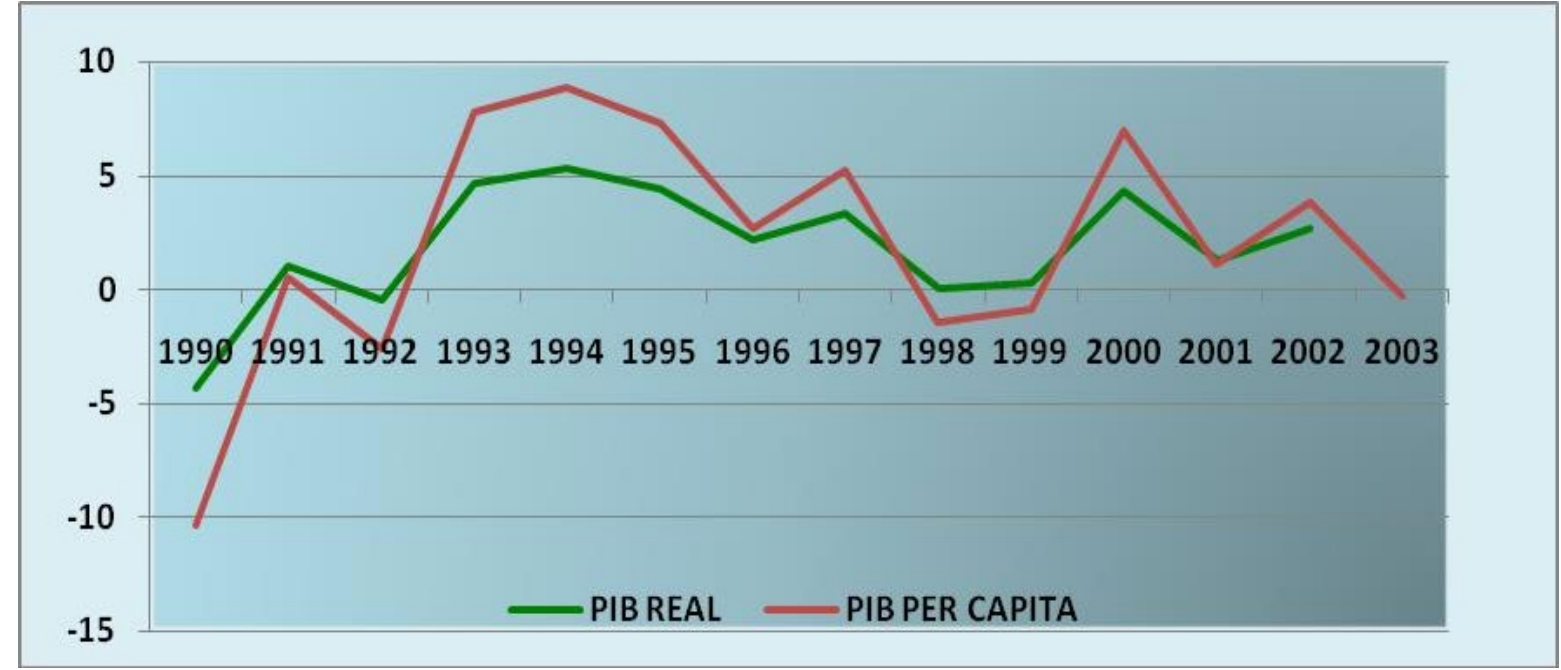

Fonte: IPEADATA

Como se sabe, o PIB real mede o crescimento do país de um ano para o outro, enquanto pode-se utilizar o PIB per capita para medir o desenvolvimento do país. Então, colocando-se no gráfico 5 as variações dos dois de 1990 a 2003, pode-se verificar que ambos tiveram um pico no ano de 1994, quando houve a implantação do Plano Real, com pontos de elevação nos anos de 1997, ano pré campanha pela reeleição, e no ano de 2000, imediatamente após uma grande desvalorização cambial ocorrida no ano de 1999, devido ao grande e constante déficit na Balança Comercial. Também é importante considerar que no ano de 2000, próximo a uma nova campanha presidencial, quando se pretendia a eleição de José Serra, Ministro da Saúde do governo FHC, candidato apoiado pelo PSDB e pelo governo, houve um aumento nos dois indicadores. Também é interessante verificar que nos anos pré-eleição e posse do Presidente Fernando Henrique Cardoso, 1998 e 1999, houve uma queda a níveis negativos da variação percentual dos dois indicadores, sendo mais evidente no caso do PIB per capita. Porém, comparativamente às grandes variações negativas antes de 1990, pode-se dizer que houve uma melhora significativa nos dois indicadores, ou seja, depois da abertura comercial desenfreada, pode-se dizer que o país teve uma reação e passou a produzir mais e a ter um nível de renda maior. 


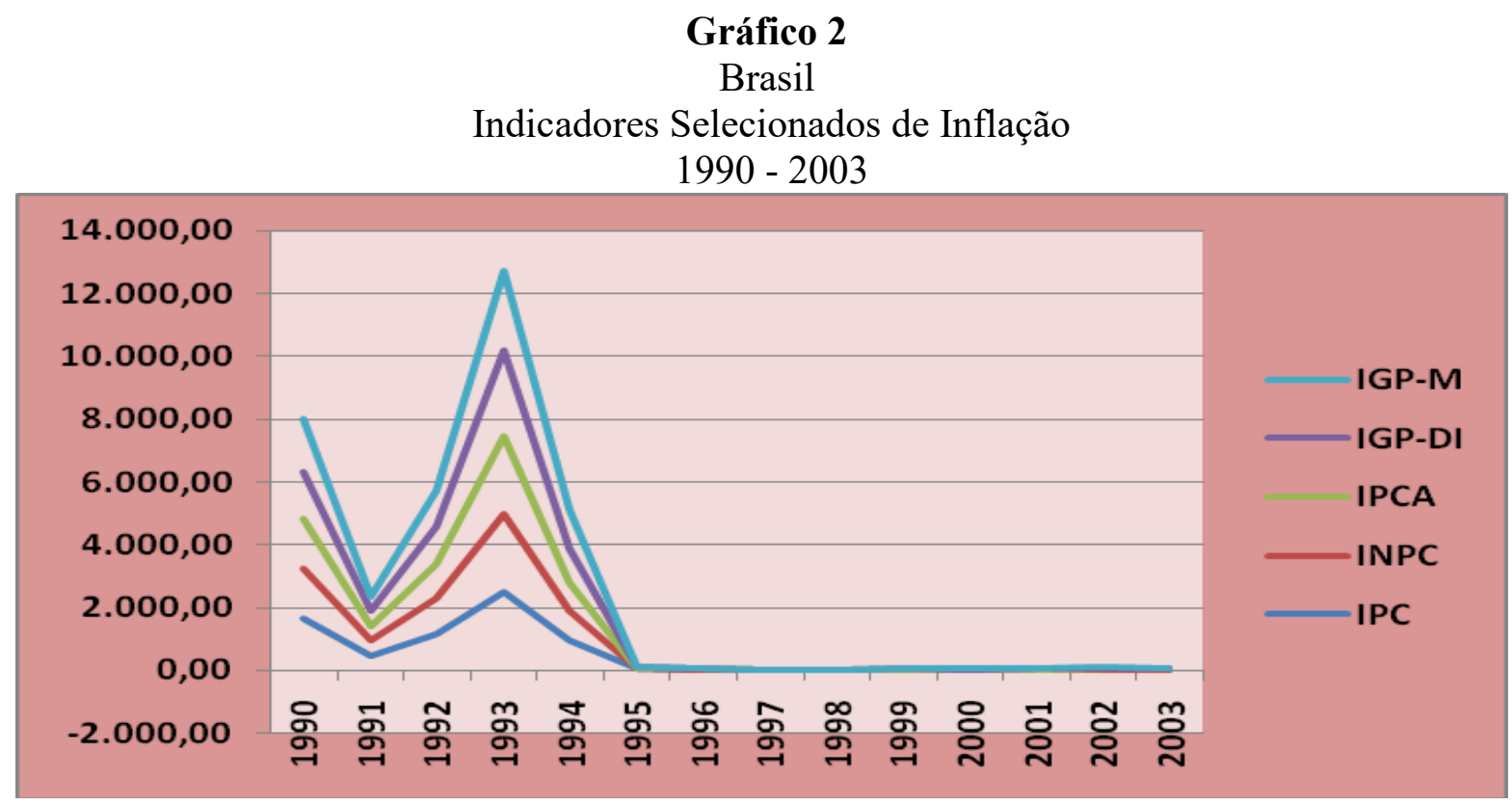

Fonte: IPEADATA

Outro indicador que é importante se analisar é a variação da inflação Isto pode ser verificado no gráfico 2. Na verdade, pode-se verificar que houve, sim, um controle da inflação, mesmo porque ela foi a meta prioritária, senão a única, de medida macroeconômica adotada no governo FHC. Na verdade, os dois governos deste presidente caracterizaram-se por um permanente trade-off entre inflação e desemprego (e crescimento muito baixo e mesmo negativo em alguns anos). Tratou-se de uma estabilização "negativa", onde a sociedade exausta pela corrosão inflacionária anterior aceitou taxas menores de índices de preços não tão “civilizadas” quanto a imprensa nativa tentou “vender' a população, pois esteve acima de 9\% nos anos de 1996, 2001, 2002 e 2003, medidas pelo INPC (Índice Nacional de Preços ao Consumidor) em troca do emprego e da renda.

Pode-se observar que há pequenas diferenças entre os diversos indicadores de inflação, além do fato de que, realmente, com a implantação do Plano Real, houve uma queda abrupta da inflação anual. Ela volta a subir no ano de 1999, quando da reeleição do Presidente Fernando Henrique Cardoso e os diversos problemas que começaram a aparecer, como a maxidesvalorização do real, por exemplo. 
Tabela 4

Brasil

Balanço de Pagamentos e Taxa de Câmbio

1990 - 2002

\begin{tabular}{|c|c|c|c|c|c|c|c|c|}
\hline Anos & $\begin{array}{c}\text { BC } \\
(\mathbf{1})\end{array}$ & $\begin{array}{c}\text { BS } \\
(\mathbf{2})\end{array}$ & $\begin{array}{c}\text { TU } \\
\mathbf{( 3 )}\end{array}$ & $\begin{array}{c}\text { SCC } \\
\mathbf{( 4 )}\end{array}$ & $\begin{array}{c}\text { Conta de } \\
\text { Capital }\end{array}$ & $\begin{array}{c}\text { Erros e } \\
\text { Omissões }\end{array}$ & SBP (5) & Taxa Câmbio \\
\hline $\mathbf{1 9 9 0}$ & 16119 & -15334 & 246 & 1031 & 629 & -775 & 885 & $1.068,70$ \\
\hline $\mathbf{1 9 9 1}$ & 10752 & -15369 & 833 & -3784 & 4592 & -328 & 480 & $12.387,00$ \\
\hline $\mathbf{1 9 9 2}$ & 10580 & -13453 & 1555 & -1318 & 163 & 875 & -280 & 326,095 \\
\hline $\mathbf{1 9 9 3}$ & 15239 & -11336 & 2206 & 6109 & 9947 & -1386 & 14670 & 0,844 \\
\hline $\mathbf{1 9 9 4}$ & 13299 & -15577 & 1602 & -676 & 10495 & -1111 & 8708 & 0,9715 \\
\hline $\mathbf{1 9 9 5}$ & 10466 & -14692 & 2414 & -1812 & 8692 & 334 & 7214 & 1,0386 \\
\hline $\mathbf{1 9 9 6}$ & -3466 & -18541 & 3622 & -18385 & 29095 & 2207 & 12917 & 1,1156 \\
\hline $\mathbf{1 9 9 7}$ & -5599 & -20350 & 2446 & -23503 & 33968 & -1800 & 8665 & 1,2079 \\
\hline $\mathbf{1 9 9 8}$ & -6753 & -25522 & 1823 & -30452 & 25800 & -3255 & -7907 & 1,7882 \\
\hline $\mathbf{1 9 9 9}$ & -6575 & -28299 & 1458 & -33416 & 29702 & -4256 & -7970 & 1,9546 \\
\hline $\mathbf{2 0 0 0}$ & -1199 & -25825 & 1689 & -25335 & 17319 & 194 & -7822 & 2,3196 \\
\hline $\mathbf{2 0 0 1}$ & -698 & -25048 & 1521 & -24225 & 19326 & 2637 & -2262 & 3,5325 \\
\hline $\mathbf{2 0 0 2}$ & 2650 & -27503 & 1638 & -23215 & 27052 & -531 & 3306 & 2,8884 \\
\hline
\end{tabular}

Fonte: BCB.

Notas:

$\mathrm{BC}=$ Balança Comercial

$\mathrm{BS}=$ Balança de Serviços

$\mathrm{TU}=$ Transferências Unilaterais

$\mathrm{SCC}=$ Saldo em Conta Corrente

$\mathrm{SBP}=$ Saldo no Balanço de Pagamentos

Pode-se observar que, imediatamente após a abertura comercial, em 1991, houve déficit na Conta Corrente e uma enorme desvalorização cambial, algo em torno de mais de mil pontos percentuais, tudo isto com o intuito de aumentar as exportações, que estavam em queda livre, e reduzir as importações, que tinham crescido bastante, principalmente em bens de capital, para poder fazer face à concorrência com a indústria externa. Quando da implantação do Plano Real, houve uma supervalorização cambial, quando o real passou a valer mais do que o dólar. Claro que isto acarretou déficits constantes na Balança Comercial que, aliado ao déficit comum dos países em 
desenvolvimento, como o Brasil, na Balança de Serviços, levou o país a uma grande perda de divisas. No ano de 2001, a taxa de câmbio tem o seu maior valor desde a implementação do Plano. Contudo, ainda não suficiente, por si só, para tornar a Conta Corrente superavitária.

\section{Tabela 5}

Brasil

Renda média dos trabalhadores

(em reais de dezembro de 1995)

\begin{tabular}{|c|c|c|c|c|c|c|c|}
\hline & $\begin{array}{c}\text { Média } \\
1994\end{array}$ & $\begin{array}{c}\text { Média } \\
1995\end{array}$ & $\begin{array}{c}\text { Média } \\
1996\end{array}$ & $\begin{array}{c}\text { Janeiro } \\
1997\end{array}$ & $\begin{array}{c}\text { Fev. } \\
1997\end{array}$ & $\begin{array}{c}\text { Março } \\
1997\end{array}$ & $\begin{array}{c}\text { Abril } \\
1997\end{array}$ \\
\hline $\begin{array}{c}\text { Trabalhadores com } \\
\text { Carteira }\end{array}$ & 519,74 & 533,22 & 570,13 & 562,58 & 559,09 & 548,27 & 555,38 \\
\hline $\begin{array}{c}\text { Trabalhadores sem } \\
\text { Carteira }\end{array}$ & 350,27 & 399,78 & 423,29 & 433,79 & 426,29 & 423,56 & 427,59 \\
\hline $\begin{array}{c}\text { Trabalhadores por } \\
\text { conta própria }\end{array}$ & 383,81 & 460,93 & 490,07 & 481,03 & 483,93 & 480,43 & 486,19 \\
\hline Empregadores & 1695,76 & 1817,76 & 1830,64 & 1769,52 & 1746,17 & 1665,32 & 1764,92 \\
\hline
\end{tabular}

FONTE: IPEA. Mercado de trabalho, conjuntura e análise, $n^{\circ} 5$ - Julho de 1997.

Pela tabela 5 pode-se observar que os empregos formais (trabalhadores com carteira assinada) são mais bem remunerados que os trabalhadores do setor informal. As oscilações desse tipo de renda são maiores do que aquelas do segmento formalizado, tanto na crise quanto no auge. Esse comportamento induziu muitos economistas a pensarem que o estancamento do processo inflacionário era suficiente para reduzir e estabilizar a pobreza, dispensando-se políticas de redistribuição de renda. A verdade é que os ganhos do setor informal se esgotam rapidamente

\section{Tabela 6}

Brasil

Evolução dos empregos informais

(como percentagem do total de emprego)

\begin{tabular}{|ll|c|c|c|c|c|c|c|}
\hline & & $\begin{array}{c}\text { Média } \\
\mathbf{1 9 9 4}\end{array}$ & $\begin{array}{c}\text { Média } \\
\mathbf{1 9 9 5}\end{array}$ & $\begin{array}{c}\text { Média } \\
\mathbf{1 9 9 6}\end{array}$ & $\begin{array}{c}\text { Janeiro } \\
\mathbf{1 9 9 7}\end{array}$ & $\begin{array}{c}\text { Fevereiro } \\
\mathbf{1 9 9 7}\end{array}$ & $\begin{array}{c}\text { Março } \\
\mathbf{1 9 9 7}\end{array}$ & $\begin{array}{c}\text { Abril } \\
\mathbf{1 9 9 7}\end{array}$ \\
\hline $\begin{array}{l}\text { Trabalhadores } \\
\text { Carteira }\end{array}$ & 23,73 & 24,14 & 24,83 & 24,41 & 24,88 & 24,91 & 25,08 \\
\hline $\begin{array}{l}\text { Trabalhadores } \\
\text { conta própria }\end{array}$ & por & 21,72 & 22,02 & 22,83 & 22,97 & 22,81 & 23,12 & 22,86 \\
\hline
\end{tabular}

FONTE: IPEA. Mercado de trabalho, conjuntura e análise, n $^{\circ} 5$ - Julho de 1997.

A tabela 6 mostra uma forte tendência para a manutenção da informalidade no mercado de trabalho, e conseqüentemente para a persistência da pobreza e da exclusão social. Cabe observar os 
percentuais tanto dos trabalhadores sem carteira assinada quanto dos trabalhadores por conta própria se elevaram período a período, totalizando no último período uma elevação de mais de um ponto percentual. Se o receituário neoliberal estivesse correto aqueles percentuais teriam que ter caído

O problema não se resumiu ao desemprego per si, mas a qualidade do emprego, ou seja, a composição do mercado de trabalho. Assim, a tabela 7 mostra como a longa década de noventa altera a estrutura do emprego aumentando a precarização das relações capital-trabalho, francamente em favor do primeiro. O volume de pessoas com carteira assinada recuou de 8,5 pontos percentuais, enquanto os sem carteiras aumentavam em 6,3 pontos percentuais e os por conta própria cresciam em 3,0 pontos percentuais.

Ainda em relação ao problema da qualidade do emprego, como visto na tabela 7, percebe-se, claramente, que a categoria "Empregador" apresenta excelente estabilidade com média de 4,3. A categoria "Conta Própria" somada a categoria "Empregados sem carteira assinada" totaliza um aumento de 9,3\%, isto é, $(6,3 \%+3,0 \%)$. Por sua vez, a categoria "Empregados com carteira assinada" caiu em 8,5\%. Admitindo-se erros e omissões a conta fecha, ou seja, os trabalhadores foram deslocados do setor formal para o setor informal.

Tabela 7

Brasil

Taxa de População Ocupada (15 anos ou mais)

1991-2001

\begin{tabular}{|c|c|c|c|c|}
\hline Ano & $\begin{array}{c}\text { Empregados com } \\
\text { carteira assinada }\end{array}$ & $\begin{array}{c}\text { Empregados sem } \\
\text { carteira assinada }\end{array}$ & $\begin{array}{c}\text { Conta } \\
\text { Própria }\end{array}$ & Empregador \\
\hline $\mathbf{1 9 9 1}$ & 53,7 & 20,8 & 20,1 & 4,4 \\
\hline $\mathbf{1 9 9 2}$ & 51,4 & 22,2 & 21,0 & 4,4 \\
\hline $\mathbf{1 9 9 3}$ & 50,5 & 23,1 & 21,1 & 4,3 \\
\hline $\mathbf{1 9 9 4}$ & 49,3 & 23,7 & 21,8 & 4,2 \\
\hline $\mathbf{1 9 9 5}$ & 48,4 & 24,1 & 22,0 & 4,5 \\
\hline $\mathbf{1 9 9 6}$ & 46,7 & 24,8 & 22,8 & 4,6 \\
\hline $\mathbf{1 9 9 7}$ & 46,4 & 24,8 & 23,3 & 4,5 \\
\hline $\mathbf{1 9 9 8}$ & 45,3 & 25,2 & 24,0 & 4,5 \\
\hline $\mathbf{1 9 9 9}$ & 44,1 & 26,9 & 23,7 & 4,3 \\
\hline $\mathbf{2 0 0 0}$ & 44,5 & 26,9 & 23,5 & 4,3 \\
\hline $\mathbf{2 0 0 1}$ & 45,2 & 27,1 & 23,1 & 3,9 \\
\hline
\end{tabular}

Fontes: IBGE 
A tabela 8 apresenta a evolução das taxas de desemprego ${ }^{32}$. Observa-se um aumento ano a ano da taxa de desemprego aberto para o Brasil culminando com uma diferença de quase dois pontos percentuais entre 1990 e 2001. Para a Região Metropolitana de São Paulo, o “core” do capitalismo brasileiro, o desemprego total aumenta de 7,6 pontos percentuais, enquanto o desemprego aberto aumenta cerca de 4 pontos percentuais.

Tabela 8

Brasil e RMGSP

Taxa de Desemprego

1990-2001

\begin{tabular}{|c|c|c|c|}
\hline Ano & $\begin{array}{c}\text { Taxa de desemprego } \\
\text { aberto - Brasil (a) }\end{array}$ & $\begin{array}{c}\text { Taxa de desemprego } \\
\text { total - RMGSP (b) }\end{array}$ & $\begin{array}{c}\text { Taxa de desemprego } \\
\text { aberto - RMGSP (c) }\end{array}$ \\
\hline $\mathbf{1 9 9 0}$ & 4,3 & 10,0 & 7,2 \\
\hline $\mathbf{1 9 9 1}$ & 4,8 & 11,7 & 8,0 \\
\hline $\mathbf{1 9 9 2}$ & 5,7 & 15,2 & 9,2 \\
\hline $\mathbf{1 9 9 3}$ & 5,3 & 14,7 & 8,7 \\
\hline $\mathbf{1 9 9 4}$ & 5,1 & 14,2 & 8,9 \\
\hline $\mathbf{1 9 9 5}$ & 4,7 & 13,2 & 9,0 \\
\hline $\mathbf{1 9 9 6}$ & 5,4 & 15,0 & 10,2 \\
\hline $\mathbf{1 9 9 7}$ & 5,7 & 15,7 & 11,7 \\
\hline $\mathbf{1 9 9 8}$ & 7,6 & 18,2 & 12,1 \\
\hline $\mathbf{1 9 9 9}$ & 7,6 & 19,3 & 11,0 \\
\hline $\mathbf{2 0 0 0}$ & 7,1 & 17,6 & 11,3 \\
\hline $\mathbf{2 0 0 1}$ & 6,2 & 17,6 & \\
\hline
\end{tabular}

Fontes: (a) IBGE/PME; (b) e (c) Dieese/Seade - Nota: RMGSP significa Região Metropolitana da Grande São Paulo

32 Taxa de Desemprego Aberto: relação entre o número de pessoas desocupadas (procurando trabalho) e o número de pessoas economicamente ativas num determinado período de referência.

Desempregados: São indivíduos que se encontram numa situação involuntária de não-trabalho, por falta de oportunidade de trabalho, ou que exercem trabalhos irregulares com desejo de mudança. Essas pessoas são desagregadas em três tipos de desemprego:

Desemprego aberto: pessoas que procuraram trabalho de maneira efetiva nos 30 dias anteriores ao da entrevista e não exerceram nenhum trabalho nos sete últimos dias;

Desemprego oculto pelo trabalho precário: pessoas que realizam trabalhos precários - algum trabalho remunerado ocasional de auto-ocupação - ou pessoas que realizam trabalho não-remunerado em ajuda a negócios de parentes e que procuraram mudar de trabalho nos 30 dias anteriores ao da entrevista ou que, não tendo procurado neste período, o fizeram sem êxito até 12 meses atrás;

Desemprego oculto pelo desalento: pessoas que não possuem trabalho e nem procuraram nos últimos 30 dias anteriores ao da entrevista, por desestímulos do mercado de trabalho ou por circunstâncias fortuitas, mas apresentaram 
Quanto à distribuição de renda, a leitura da tabela 9 dispensa comentários. Ocorreu nos anos noventa uma estabilidade "perversa" absolutamente perfeita no Brasil. O neoliberalismo tupiniquim conseguiu manter os pobres no seu devido lugar, ou seja, na pobreza. O coeficiente de Gini - um indicador de desigualdade muito eficiente e amplamente aceito - foi de 0,58 em 1992 e passou para 0,60 em 1993, permanecendo neste patamar até o final da década. Note-se que todos os anos da série têm este valor com exceção de 1992. A média, é claro, converge para 0,60. Considerando-se, pois, o referido indicador não ocorreu nenhuma desconcentração da renda familiar na década mais que pedida. Os $20 \%$ mais pobres ${ }^{33}$ continuaram se apropriando de pouco mais de $2 \%$ da renda nacional, com a média convergindo para $2,2 \%$. Quando se aumenta a fração populacional para os $40 \%$ mais pobres, percebe-se que o percentual apropriado cai de $8,4 \%$ para $8,1 \%$, oscilando em torno de $8 \%$. Metade da população brasileira - o que corresponde a 85 milhões de brasileiros - recebeu na média 12,4\% na década de noventa, sendo que este percentual era de 13,1 em 1992 e caiu para 12,6 em 1999.

\section{Tabela 9}

Brasil

Indicadores de Desigualdade de Renda: Coeficiente de Gini e

Percentual da Renda Apropriada por frações da população

$1992 / 1999$

\begin{tabular}{|c|c|c|c|c|c|c|c|}
\hline Ano & $\begin{array}{l}\text { Coeficiente } \\
\text { de Gini }\end{array}$ & $\begin{array}{c}20 \% \\
\text { mais } \\
\text { pobres }\end{array}$ & $\begin{array}{c}40 \% \\
\text { mais } \\
\text { pobres }\end{array}$ & $\begin{array}{c}50 \% \\
\text { mais } \\
\text { pobres }\end{array}$ & $\begin{array}{l}20 \% \\
\text { mais } \\
\text { ricos }\end{array}$ & $\begin{array}{l}10 \% \text { mais } \\
\text { ricos }\end{array}$ & $\begin{array}{l}1 \% \text { mais } \\
\text { ricos }\end{array}$ \\
\hline 1992 & 0,58 & 2,3 & 8,4 & 13,1 & 62,1 & 45,8 & 13,2 \\
\hline 1993 & 0,60 & 2,2 & 7,9 & 12,3 & 64,5 & 48,6 & 15,0 \\
\hline 1995 & 0,60 & 2,3 & 8,0 & 12,3 & 64,2 & 47,9 & 13,9 \\
\hline 1996 & 0,60 & 2,1 & 7,7 & 12,1 & 64,1 & 47,6 & 13,5 \\
\hline 1997 & 0,60 & 2,2 & 7,8 & 12,1 & 64,2 & 47,7 & 13,8 \\
\hline 1998 & 0,60 & 2,2 & 7,9 & 12,2 & 64,2 & 47,9 & 13,9 \\
\hline 1999 & 0,60 & 2,3 & 8,1 & 12,6 & 63,8 & 47,4 & 13,3 \\
\hline Média & 0,60 & 2.2 & 8,0 & 12,4 & 63,9 & 47,5 & 13,8 \\
\hline
\end{tabular}

Fonte: Henriques (2000)

Por outro lado, os $20 \%$ mais ricos iniciam a série com $62,1 \%$ da renda total e a terminam com

33 O Censo demográfico do IBGE de 2000 mensurou a população brasileira em 169.872 .856 habitantes, para efeitos de facilitar os cálculos considera-se neste artigo uma população de 170 milhões. 
$63,8 \%$, sendo a média de 63,9\%. Por sua vez, os 10\% mais ricos apropriam em 1992, 45,8\% da renda e passam a apropriar 47,4\% em 1999, com média de 47,5\%. A fração dos muitos ricos - 1\% da população - detinha 13,2\% em 1992 e passa a deter 13,3\% em 1999. A média foi de 13,8\%.

Quando se compara os 1\% mais ricos que correspondia a um milhão e setecentas mil pessoas e absorvia 13,8\% com os 50\% mais pobres que somavam 85 milhões de pessoas e que ficava na média com $12,4 \%$ da renda. Duas constatações se impõem. Em primeiro lugar que a fração dos muitos ricos teve acesso a mais renda do que os 50\% mais pobres. Em segundo lugar a razão entre o número dos $50 \%$ mais pobres e o 1\% mais rico é igual a cinqüenta e seis. Ou seja, 56 brasileiros tiveram que sobreviver com uma renda menor do que aquela disponível para um membro rico desta sociedade.

Se a comparação é entre os muitos ricos e os $20 \%$ mais pobres, os resultados tornam-se mais dramáticos. A razão entre o número dos $20 \%$ mais pobres e o $1 \%$ mais rico é igual a 125 . Isto que dizer que 125 pessoas receberam uma renda que correspondeu àquela percebida por uma única pessoa. Note-se que tanto no parágrafo anterior quanto neste, se trata de fluxo de renda e não de riqueza acumulada.

Finalizando, são índices alarmantes que ultrapassam a própria tese de que o capitalismo "naturalmente" gera desigualdade, para outra de que - em algumas sociedades - o capitalismo é capaz de gerar desigualdades "anti-civilizatórias".

No caso do Brasil, a abertura comercial de 1990, logo após uma década de altíssimas taxas de inflação e desemprego, levou a uma quebra do parque industrial nacional, que teve de fazer "mágica" para poder, no menor espaço de tempo possível, concorrer com as indústrias externas. Quando da implantação do Plano Real, em 1994, com sua famosa âncora cambial e acúmulo fictício de divisas, via capital especulativo, e medida única de política macroeconômica a queda da inflação, ou melhor, o trade-off entre inflação e desemprego. O único ano em que a inflação efetivamente caiu, foi o de 1998. Claro que, comparativamente aos índices que se tinham na década anterior, houve uma queda abrupta da inflação, mas não tão pequena que justificasse esse trade-off. Aliado a isso, tem-se a supervalorização do real, o que leva a déficits constantes na Balança Comercial. 


\section{Capítulo 3}

\section{O período 2003-2010: "A recuperação nacional restringida" \\ 1. De como a esperança venceu o medo e depois perdeu ou a política como exercício de "transfiguração"}

No final de 2002 o Presidente Fernando Henrique Cardoso insistia na tese de que o Brasil estava no rumo certo. A população brasileira que deu $61,3 \%{ }^{34}$ dos votos válidos para Luiz Inácio Lula da Silva discordava do então Presidente Cardoso. Se a estabilidade de preços tornou-se um bem público que todos deveriam proteger, as outras variáveis macroeconômicas haviam se transformado em males que a sociedade queria superar. Passados dois anos de governo do Presidente Lula ficou a impressão de que o sociólogo Fernando Henrique estava certo, em parte, pois a população parecia concordar com o caminho (o rumo certo, segundo Cardoso), mas desejava mudar o piloto. Foi a segunda parte do desejo popular que não estava visível em 2002, nem para o político Cardoso nem para o sociólogo Fernando.

Para chegar até a vitória o Presidente Lula e seu partido, o PT fizeram alguns movimentos de acomodação. Em primeiro lugar, a constituição de uma frente ampla o bastante para incluir, além do Senador José Alencar como Vice, sinalizando uma aliança pragmática entre o trabalho e o capital, figuras históricas tradicionais como Orestes Quércia, Roberto Requião, José Sarney e Itamar Franco. Em segundo lugar, uma carta aos brasileiros, onde ficavam claras as intenções de bom comportamento do Partido e do candidato quanto às regras de mercado.

A verdadeira e mais importante mudança foi simbólica. Eleger um ex-operário era um avanço notável em uma sociedade conservadora e submetida a um rigoroso controle social exercido pela grande imprensa. As forças políticas que haviam guindado o Presidente Fernando Henrique ao poder havia 10 anos, trabalhava com uma estratégia de longa duração, algo como um "reinado" de pelo menos 20 anos. Desmontar esta estratégia continuista e conservadora foi uma vitória que exigiu seu preço. Um preço muito alto.

A primeira grande mudança do novo governo deu-se em um campo que aparentemente não tem tanta importância, mas que é essencial em tempos de mundialização do capital e multilateralismo.

\footnotetext{
${ }^{34}$ Folha de São Paulo, 28 de outubro de 2002.
} 
A política externa do governo do Presidente Luiz Inácio Lula da Silva foi desde o início um diferencial positivo, como apontou Amorim:

A diplomacia vive um momento de grande dinamismo que reflete as prioridades do governo Lula nas áreas interna e externa, como combater a fome e a pobreza, contribuir para a criação de uma nova geografia comercial e adotar postura firme e ativa nas negociações multilaterais, inclusive regionais; com vistas a assegurar um espaço regulatório multilateral justo e equilibrado. Está ainda o imperativo de preservar a nossa capacidade soberana de defender o desenvolvimento que desejamos para o nosso país ${ }^{35}$.

Importante ressaltar, ainda, no campo da economia política internacional que a vitória do Presidente Lula enterrou de vez a imposição por parte dos Estados Unidos de uma agenda unilateral para formação da Área de Livre Comércio das Américas (ALCA). Em consonância com este movimento estratégico, houve o fortalecimento do MERCOSUL e do clube dos vinte ${ }^{36}$.

No campo da política econômica "estrito senso" a polaridade histórica que opõe de um lado uma heterodoxia estimuladora de políticas expansivas e de outro uma ortodoxia sempre disposta a puxar o freio de mão já estava instalada desde a campanha e continuou operando dentro do governo. Em certo sentido e durante três longos anos a política macroeconômica foi a mesma dos anos do Presidente Fernando Henrique Cardoso. O que muitos se perguntavam, incluindo petistas da primeira hora, era como se podia conciliar uma política externa independente, solidária e emancipatória associada com propostas gerais de redução da pobreza e da desigualdade, tendo como eixo da macroeconomia, políticas de contração da demanda?

A resposta a pergunta acima foi dada recentemente por importantes dirigentes do Partido dos Trabalhadores (PT) e dos governos do Presidente Luiz Inácio Lula da Silva e da Presidenta Dilma Rousseff. Mercadante (2009) e Mantega (2012) justificaram a necessidade de um período de ajustamento ou de transição entre o modelo neoliberal e o modelo denominado de novodesenvolvimentismo. O problema maior é que, na prática, se utilizou de todo um mandato, ou seja,

\footnotetext{
${ }^{35}$ AMORIM, Celso. Palestra. Seminário Atualidade de San Tiago Dantas. 27 de setembro de 2004. Disponível em: http://www.acrj.org.br. Acesso em 15 de dezembro de 2011.

36 Trata-se da constituição de um grupo de países com agenda independente no âmbito da Organização Mundial do Comércio (OMC).
} 
2003-2006 para realizar a transição. Os argumentos sofrem do defeito de quem fala de si mesmo e de seus feitos.

\section{2. “Herança Maldita”, Paloccismo e Primeiro Lula ou para que mudar o rumo?}

Considerando a existência de uma "herança maldita" vinda do governo anterior e representada por um acordo com o FMI de combate à inflação baseado em um Sistema de Metas de Inflação, o Presidente eleito nomeia Antônio Palocci, Ex-prefeito de Ribeirão Preto/SP e Coordenador do programa de governo para o Ministério da Fazenda e Henrique Meirelles, Ex- presidente mundial do BankBoston para o Banco Central, como gestores da "herança", de forma a garantir a gestão financeira acordada com o FMI, além da continuidade de reformas planejadas pelo governo anterior. Cabe aqui lembrar que a dupla Palocci-Meirelles renovou o acordo com o $\mathrm{FMI}^{37}$ por mais dois anos, preservando assim a subordinação da economia brasileira ao receituário da banca internacional.

No que consistia o modelo de controle inflacionário do novo governo? As bases eram as premissas do velho monetarismo friedmaniano. "Inflação foi, é, e será sempre um fenômeno monetário”. Para os monetaristas, há sempre um excesso de demanda em alguma parte do sistema, assim como há uma contrapartida de um excesso de moeda em circulação. Uma excelente âncora monetária é a taxa de juros. O modelo é muito simples e prático: correlacionam- se a taxa de juros e a taxa de inflação, de maneira que quanto mais as expectativas ou a inflação efetiva se afastam da meta fixada, maior deve ser a taxa de juros comandada pela autoridade monetária.

Aqui necessário se faz um parênteses: A constituição dos índices das expectativas de preços e de expectativas de juros é feita por levantamento do Banco Central junto aos 100 mais importantes operadores e analistas do mercado financeiro, ou seja, os agentes que estão mais interessados em juros altos fornecem as informações necessárias e suficientes para formá-los. Mas não é só. As altas taxas de juros "capturam" os capitais de curto prazo, principalmente os especulativos que auxiliam na rolagem da própria dívida interna. Ou seja, na medida em que reduz a liquidez do sistema, as autoridades monetárias sustentam o dogma monetarista de controle inflacionário, mas de fato estão

\footnotetext{
${ }^{37}$ O novo acordo com o FMI não foi feito sem resistências dentro do governo. Ele encerrou-se em março de 2005, quando vários membros do governo votaram que o mesmo não precisava ser renovado. A dupla Palocci-Meirelles concordou com a não renovação, mas manteve a política subjacente ao acordo. José Dirceu era o principal opositor de Palocci, daí as facilidades com que este último teve seu nome ligado a um esquema de "caixa dois". Conhecendo- se as práticas de financiamento das campanhas no Brasil é possível inferir que vazamentos deste tipo só são possíveis através de "traição" ou de "fogo amigo".
} 
produzindo os recursos para pagar os encargos da dívida, enquanto aumentam o principal através de novos encargos financeiros.

\begin{tabular}{|c|c|c|c|c|c|c|}
\hline & & $\begin{array}{r}\text { Tabela } \\
\text { Brasil } \\
\text { Superávit } \mathrm{Pr} \\
(\% \text { do } \mathrm{P} \\
\end{array}$ & irio & & & \\
\hline & $\begin{array}{c}1^{\circ} \text { mandato } \\
\text { FHC }\end{array}$ & $\begin{array}{c}2^{\circ} \text { mandato } \\
\text { FHC }\end{array}$ & 2002 & 2003 & 2004 & 2005 \\
\hline $\begin{array}{l}\text { Superávit } \\
\text { Primário }\end{array}$ & 0,0 & 3,55 & 3,89 & 4,37 & 4,61 & 4,84 \\
\hline
\end{tabular}

Fonte: Banco Central do Brasil

A política monetária contracionista não opera sozinha, ela precisa de arrocho fiscal. O aperto fiscal é realizado pelo corte dos gastos públicos e pelo aumento da carga tributária, criando-se os mega-superávites primários ${ }^{38}$. A tabela 10 mostra que durante o primeiro governo do Presidente Fernando Henrique Cardoso este indicador ficou próximo de zero, aumentou para 3,55 no segundo mandato, voltou a crescer para 3,89 no último ano de governo (2002), pulou respectivamente para 4,37 em 2003; 4,61 em 2004 e 4,84 em 2005. Cabe lembrar que a exigência do FMI era de 4,25\%, ou seja, o governo brasileiro foi mais realista que o "Rei" ou mais capitalista que a banca.

\footnotetext{
${ }^{38}$ O superávit primário é expresso como percentagem do PIB e apesar de ideologicamente se recobrir com a linguagem séria e douta de "austeridade fiscal" é preciso entender seu real significado. Suponha uma economia muito simples que produza uma quantidade mínima de bens, tais como pão, manteiga, bicicletas, educação e saúde. As pessoas comem pão com manteiga, apenas. Elas se locomovem de bicicleta e cada uma delas precisa de uma consulta médica e de uma matrícula escolar. Suponha quantidades inteiras em um tempo " $t$ " qualquer, ou seja, 1000 unidades de pão, 100 unidades de manteiga, 1000 bicicletas, 1000 consultas médicas e 1000 matrículas escolares. Suponha uma população de 1000 habitantes. Quando as autoridades econômicas se orgulham de terem obtido 5,0\% de superávit fiscal, isto significa exatamente que: 50 pães, 5 caixas de manteiga, 50 bicicletas, 50 consultas médicas e 50 matriculas escolares foram "jogadas" em um depósito de inservíveis para apodrecerem ou enferrujarem, enquanto pessoas não são atendidas nas UPAs, carteiras ficam vazias nas Escolas, parte da população anda a pé. Agora se podem multiplicar algumas dessas coisas por milhões, como bicicletas ou por bilhões, como pães. Qual a racionalidade de se jogar fora bilhões de pães
} 
Tabela 11

Brasil - Períodos Selecionados

Taxas de juros reais efetivas (\%)

\begin{tabular}{|c|c|c|c|c|c|}
\hline & Dez./2002 & Jul./2003 & Ago./2003 & Set./2003 & Out./2003 \\
\hline Taxa & 5,8 & 6,8 & 7,4 & 7,6 & 8,7 \\
\hline & Nov./2003 & Dez./2003 & Jan./2004 & Fev./2004 & Mar./2004 \\
\hline Taxa & 11,4 & 12,9 & 13,7 & 13,9 & 14,4 \\
\hline & Abr./2004 & Maio./2004 & Jun/2004 & Jul./2004 & Ago./2004 \\
\hline Taxa & 14,3 & 13,5 & 11,9 & 10,2 & 9,3 \\
\hline
\end{tabular}

Fonte: Banco Central do Brasil e IBGE

A tabela 11 mostra que o governo do Presidente Luiz Inácio Lula da Silva recebeu uma taxa de juros reais ${ }^{39}$ baixa, isto é de 5,8\% em dezembro de 2002. Em julho de 2003 a taxa saltou para 6,8 e sempre em um crescendo atingiu a marca de 14,4 em março de 2004. Como a inflação aumenta a taxa real de juros declina até atingir 9,3 em agosto de 2004. A taxa atinge 12,7\% em março de 2005, para depois se estabilizar em 14,0\%.

Talvez para compensar políticas econômicas tão ortodoxas, o governo tenha tomado algumas decisões importantes, tais como:

(a) suspendeu o processo de privatização que já tinha alienado parte importante do patrimônio público;

(b) o BNDES voltou a sua função de banco financiador dos investimentos em empresas nacionais;

(c) a Petrobrás fixou um amplo programa de compra de plataformas e de navios construídos no país, com o objetivo de estimular a produção nacional.

\section{Tabela 12}

Brasil

Evolução do PIB

2003-2010

\begin{tabular}{|c|c|c|c|c|c|c|c|c|}
\hline Ano & $\mathbf{2 0 0 3}$ & $\mathbf{2 0 0 4}$ & $\mathbf{2 0 0 5}$ & $\mathbf{2 0 0 6}$ & $\mathbf{2 0 0 7}$ & $\mathbf{2 0 0 8}$ & $\mathbf{2 0 0 9}$ & $\mathbf{2 0 1 0}$ \\
\hline PIB & 1,1 & 5,7 & 3,2 & 3,7 & 4,0 & 5,7 & $-0,2$ & 5,0 \\
\hline
\end{tabular}

Fonte: IBGE

\footnotetext{
${ }^{39}$ A taxa de juros reais é aquela que efetivamente mede o custo da moeda e do seu uso e depende do nível geral de preços. Assim, mesmo com taxas nominais crescentes, quando a inflação aumenta a taxa de juros reais tem tendência declinante.
} 
O primeiro ano do governo Lula apresentou um quadro econômico tão estagnacionista que decepcionou alguns aliados ${ }^{40} \mathrm{e}$ foi motivo de júbilo no campo adversário. A partir do segundo ano de mandato a economia apresentou crescimento do PIB na ordem de 5,7\%, de maneira que no período 2003-2010 a média anual foi de 3,5\% (conforme tabela 12), contra 2,3\% ${ }^{41}$ do período 1995-2002 do Presidente Fernando Henrique. O que efetivamente determinou o primeiro ano de estagnação e o que puxou no segundo ano a locomotiva da "lulaeconomics"?

No primeiro ano o novo governo seguiu exatamente as mesmas políticas do governo anterior. Resultado: corte na demanda, nos investimentos e aumento do desemprego. De acordo com o IBGE o investimento caiu em 6,6\%. Como a renda cresceu em 1,1\% e o crescimento demográfico foi de 1,3\%, então ocorreu uma queda na renda per capita. Em face da queda do investimento, dos gastos do governo e do consumo, isto é, da demanda interna agregada, o PIB não foi negativo porque as exportações cresceram em $21 \%{ }^{42}$.

\section{Tabela 13}

Diversos Países

Taxas básicas de juros reais

2004

\begin{tabular}{|c|c|c|c|c|}
\hline Países & Turquia & Brasil & "Países Emergentes" & Países Ricos \\
\hline Taxa (\%) & 14,8 & 9,3 & 2,7 & 0,3 \\
\hline
\end{tabular}

Fonte: Global Invest.

Em 2004, a locomotiva da "lulaeconomics" foram as exportações. Até parecia o Professor Delfim Neto dizendo no início dos oitenta: "exportar é o que importa". A produção industrial cresceu

\footnotetext{
${ }^{40}$ O jornal Folha de São Paulo estampou em manchete do dia 7.11.2003: "Fiesp se queixa ao FMI de política fiscal”, e a matéria interna do seu caderno Dinheiro da mesma edição noticia que os empresários paulistas, representados pela sua outrora poderosa Federação, foram à Sra. Anne Krueger, vice-diretora-gerente do FMI, queixar-se do aperto fiscal a que a administração fazendária do governo Lula os submete. Mas a professora Maria da Conceição Tavares, em artigo publicado no mesmo jornal, edição de 9.11.2003, diz que os novos “donos do poder" são o Banco Central e a Secretária do Tesouro, e mesmo os ministros da Fazenda e do Planejamento são cada vez mais apenas simbólicos. E ela entende de governo Lula e do poder financeiro. V. "os novos donos do poder", FSP, São Paulo, 9.11.2003 apud Oliveira (2005),

${ }^{41}$ IBGE - Online. Acesso em 28 de dezembro de 2001

${ }^{42}$ Fonte: IBGE - Online. Acesso em 28 de dezembro de 2011.
} 
em $8,3 \%{ }^{43}$, a melhor taxa desde 1986 , enquanto o PIB crescia $5,7 \%^{44}$. O desemprego aberto medido pelo IBGE caiu de 12,3\% em 2003 para $11,5 \%$ em $2004^{45}$. Olhando a demanda agregada o que se observa? Taxa de juros reais alta, a segunda maior do mundo, isto é, 9,3\% ${ }^{46}$, o que desestimula o investimento. Superávit Primário de $4,61 \%$ do PIB o que significa gastos públicos baixos. Salários reais em queda, o que acarreta, pelo menos, não-crescimento do consumo. Conclusão: demanda interna agregada deprimida. Novamente a resposta está nas exportações que cresceram 32,0\% ${ }^{47} \mathrm{em} 2004$.

Pode-se dizer que a reanimação das exportações se deveu aos custos salariais baixos e ao aquecimento da demanda externa por produtos brasileiros. Estes são dois aspectos essenciais da resposta. Um terceiro elemento foi a compressão da absorção interna, pois políticas econômicas restritivas empurram as mercadorias (que não podem ser compradas internamente por falta de renda) para o exterior. Contudo a resposta completa deve incluir a política diplomática e a política comercial do governo. Enquanto a dupla Palocci-Meirelles jogava água fria na caldeira da locomotiva, a dupla Lula-Celso Amorim fazia multilateralismo pragmático. Parodiando o próprio Presidente Luiz Inácio Lula da Silva: "Nunca antes na história deste país um presidente foi um caixeiro-viajante tão eficiente".

Como ocorreu em 1984, ou seja, 20 anos antes, em 2004 o crescimento do setor exportador foi gradualmente se espalhando para a economia interna, através do único instrumento possível: o aumento da massa de salários. O IBGE apresentou informações que confirmam um aumento de $9,0 \%{ }^{48122}$ na massa salarial em 2004. Outro elemento importante para o soerguimento do mercado doméstico foi o aumento do volume de crédito, principalmente o crédito consignado para servidores públicos, aposentados, e pensionistas, pois como a garantia do banco era total, os juros podiam ser mais baixos. Milhares destas pessoas, talvez milhões, hoje, são prisioneiros dos bancos, mas seus padrões de vida caíram bastante, dado que a maioria dispõe de apenas metade de seus proventos.

No último quadrimestre de 2004, as autoridades econômicas resolvem combinar juros reais

\footnotetext{
${ }^{43}$ Fonte: IBGE. Pesquisa Industrial Mensal. Acesso em 02 de janeiro de 2012

${ }^{44}$ Fonte: tabela 28

${ }^{45}$ Fonte: IBGE - Online. Acesso em 28 de dezembro de 2011

${ }^{46}$ Fonte: tabela 29

${ }^{47}$ Fonte: IBGE - Online. Acesso em 28 de dezembro de 2011.

${ }^{48}$ Fonte: IBGE. Pesquisa Industrial Mensal. Acesso em 02 de janeiro de 2012
} 
mais altos, valorização do real e aumento de tributos. Estas medidas derrubaram o investimento, o consumo e as exportações. O governo insistia na política do "stop and go". O problema era de que o único operador eficiente entre as autoridades econômicas era o Banco Central. O Ministério do Planejamento que já fora o ministério do crescimento na "era Sayad" havia sido "apagado". O Ministério da Fazenda executava tarefas de rotina e delegava ao Banco Central. Este operava de acordo com os interesses da média das expectativas dos operadores da banca. A lógica do BACEN era limitar o crescimento a 3,5\%. Erraram o alvo e deu 3,2\%. Seguramente uma das equações do sistema do BACEN continha um viés ou a média das expectativas divergia das reais expectativas daquilo que o mercado realmente desejava. É preciso tomar cuidado com estas entidades por demais caprichosas, quase sobrenaturais. Quem sabe com certeza o que o mercado quer, a não ser ele mesmo.

O fato é que a expansão ocorrida nos três primeiros anos do governo do Presidente Luiz Inácio Lula da Silva não era sustentável e, como visto, baseava-se nas exportações. Contudo, seja qual for o componente da demanda agregada que esteja puxando o crescimento econômico é preciso compreender duas questões: (a) sem investimento o crescimento só é possível enquanto houver capacidade ociosa, chegando próximo do pleno emprego os preços sobem; (b) o investimento é a variável-chave da dinâmica capitalista, sem ele nenhum crescimento é auto- sustentado. Significava que os juros reais precisavam cair para que os investimentos fossem realizados. Como apontava o documento do IEDI “o trinômio juro, câmbio e investimento público é o problema, pois todos estão fora do lugar 49 .

No final de 2005 muitos achavam que era hora de mudar, menos o "paloccismo radical" 50,51 que no início do governo afirmava que as medidas econômicas eram apenas um remédio amargo necessário para se atingir o desenvolvimento auto-sustentado, mas pretendeu prorrogar as políticas restritivas por tempo indefinido, através de uma proposta elaborada no Ministério do Planejamento. A proposta foi rechaçada por alguns ministros, tendo a frente a ministra Dilma Rousseff.

\footnotetext{
${ }^{49}$ IEDI, O sol e a peneira, 30 de novembro de 2005.

50 “paloccismo radical” é uma forma grave e crônica de transformismo onde os problemas de uma economia capitalista semiperiférica são metamorfoseados em virtudes. Onde medidas ortodoxas ditas como emergenciais são transformadas em permanentes.

51 Transformismo refere-se ao processo de adesão (individual ou coletiva) ao bloco histórico dominante, por parte de lideranças e/ou organizações políticas dos setores subalternos da sociedade, com o abandono de suas antigas concepções/posições políticas. Fonte: FILGUEIRAS \& GONÇALVES, 2007, p. 250.
} 


\section{Superando o paloccismo ou o segundo Lula: rumo ao PAC ou por que somos todos keynesianos}

A possibilidade de adentrar o último ano de mandato e, ao mesmo tempo, ano eleitoral de $2006^{52}$ com um desempenho econômico medíocre acendeu a luz vermelha (ou terá sido de outra cor?) no comando do partido hegemônico da frente que sustentava o governo do Presidente Luiz Inácio Lula da Silva. Uma das discussões presentes era de que o paloccismo enquanto processo transitório estava ganhando força como forma permanente de gestão e de poder. A direção partidária chegou a conclusão que era possível um segundo mandato, porém que este dependeria de algumas mudanças (ou promessas de mudanças) em pontos sensíveis da política econômica. Era preciso sinalizar para os eleitores que havia condições e vontade política para crescer.

Consideramos fundamental reduzir de forma significativa e sustentada as taxas de juros, algo totalmente compatível com o cenário internacional, com a situação das contas do governo e com estabilidade de preços. Estimamos imprescindível acelerar a execução orçamentária, ampliar os investimentos em infra-estrutura e nas políticas sociais, acelerar a reforma agrária e melhorar o funcionamento do conjunto do governo. O caminho do crescimento permite reduzir a relação dívida/PIB, sem os sacrifícios resultantes das metas do superávit primário, que devem ser reduzidos ${ }^{53}$.

A resolução do diretório nacional do Partido dos Trabalhadores iniciava o processo de repúdio "relativo" ao paloccismo. Palocci começara a ser "fritado". Como se necessita muito de figuras como o ex-ministro era melhor fritá-lo por razões estranhas ao labor ministerial. Palocci e sua equipe resistiram até março de 2006, para serem finalmente exonerados pelo Presidente. O caminho estava aberto para um derrotado do primeiro ano: Guido Mantega. O economista Mantega começou o governo como ministro do Planejamento, mas tinha independência e autoridade, e era desenvolvimentista demais, o que ameaçava o protagonismo de Palocci. Desse modo, Mantega foi deslocado para o BNDES, enquanto o "cinzento" Paulo Bernardo assumia o Planejamento, mas recebia ordens do ministro da Fazenda.

Guido Mantega assume em meados de maio e em entrevista coletiva afirma que: "[é

\footnotetext{
${ }^{52}$ Folha de São Paulo, 08 de dezembro de 2005.

53 Jornal O Globo de 11 de dezembro de 2005.
} 
necessário que] os juros baixem de forma ainda mais consistente, já que há condições para que isto aconteça, porque o país está com a inflação controlada e já conquistou a maioridade para atingir o desenvolvimento sustentado" ${ }^{44}$. O novo ministro da Fazenda não conseguiu realizar grandes mudanças até o final do ano, porém atuou em duas frentes fundamentais, ambas subordinadas ao seu Ministério. Acompanhou o Banco Central para que o mesmo não interrompesse o procedimento de redução (mesmo que lenta) da taxa de juros e pressionou a Receita Federal para que mantivesse saldos primários iguais a meta e não acima, como ocorria na era palocciana.

O Presidente Luiz Inácio Lula da Silva foi reeleito. A principal questão explorada na campanha, pela oposição que começou toda farra de juros reais e superávits primários altos, foi o baixo crescimento do período 2003-2006, ou seja, 3,5\%. ${ }^{55}$ Insiste-se, que no período do Presidente Cardoso o crescimento pode ser medido como de 2,3\% ou de 1,9\% dependendo do Instituto e da metodologia. Contudo, a palavra de ordem pós-eleitoral passou a ser "vamos destravar $a$ economia”. O Presidente reeleito não ficou no discurso, convocou uma equipe para criar um programa de crescimento econômico sustentado. Desse modo, estava lançado, em 22 de janeiro de 2007, o Programa de Aceleração do Crescimento - 2007/2010 ${ }^{56}$, logo conhecido como PAC.

O PAC, na tradição estruturalista latino-americana, partiu de um diagnóstico onde havia um conjunto de gargalos que "travavam" o crescimento da economia brasileira. ${ }^{57}$ Tais pontos de estrangulamentos estavam concentrados na infra-estrutura física, como transporte e energia; e infra-estrutura social, como saneamento e habitação. Assim, era nestas áreas que deveriam se concentrar os investimentos. Ficaram definido metas de crescimento do PIB de 4,5\% para 2007 e de 5,0\% para o triênio de 2008-2010. As medidas foram enquadradas em cinco categorias:

i. Investimentos em infra-estrutura;

ii. Estímulo ao crédito e ao financiamento;

iii. Melhoria ao ambiente de investimento;

iv. Desoneração e aperfeiçoamento do sistema tributário;

\footnotetext{
${ }^{54}$ Folha de São Paulo, 17 de maio de 2006.

${ }^{55}$ IBGE - Online. Acesso em 02 de janeiro de 2012

${ }^{56}$ Disponível em: www.fazenda.gov.br . Acesso em 28 de dezembro de 2011

${ }^{57}$ Disponível em: www.fazenda.gov.br . p. 6. Acesso em 28 de dezembro de 2011
} 
v. Medidas fiscais de longo prazo. ${ }^{58133}$

Tabela 14

Brasil

PAC - Investimento em infraestrutura

Bilhões de reais

2007-2010

\begin{tabular}{|l|c|}
\hline Eixo de Planejamento & Valores distribuídos \\
\hline Logística (sobretudo transportes) & 58,3 \\
Orçamento da União & 33,3 \\
Estatais, federais e de demais fontes & 25,3 \\
\hline Energia & 274,8 \\
Orçamento da União & - \\
Estatais, federais e de demais fontes & 274,8 \\
\hline Infra-estrutura social & 170,8 \\
Orçamento da União & 34,8 \\
Estatais, federais e de demais fontes & 136,0 \\
\hline Total do PAC & 503,9 \\
Orçamento da União & 67,8 \\
Estatais, federais e de demais fontes & 436,1 \\
\hline
\end{tabular}

Fonte: Programa de Aceleração do Crescimento/PAC - 2007-2010.

O PAC, em boa medida, desconsidera as observações de Giovanni Arrighi (1997) em " $A$ Ilusão do Desenvolvimento", onde aquele cientista social mostra que os entraves ao desenvolvimento estão muito além do que os teóricos do desenvolvimentismo chamam de gargalos. Vinte e três anos antes de Arrighi, em 1974, no final de um "milagre", o maior economista brasileiro, Celso Furtado em "O mito do desenvolvimento econômico" chamava a atenção sobre problemas semelhantes. "Mito" para Furtado e "Ilusão” para Arrighi. Para os iludidos é suficiente uma boa dose de keynesianismo bastardo ${ }^{59}$ para se vender novas esperanças de chegada ao Primeiro

\footnotetext{
${ }^{58}$ Disponível em: www.fazenda.gov.br. p. 4. Acesso em 28 de dezembro de 2011.

${ }^{59}$ Keynes abominou a dominância do capital financeiro. Aceitou a existência de algumas bolhas de especulação em torrentes de produção e nunca o contrário. Keynes propôs a socialização dos investimentos sob o controle do Estado. Ninguém deveria denominar-se keynesiano sem entender a filosofia social da Teoria Geral.
} 
Mundo (eufemismo ultrapassado para núcleo orgânico do capitalismo). Não significa que um país isolado, principalmente com as potencialidades do Brasil não possa seguir a trilha do desenvolvimento e atingir o núcleo orgânico. É claro que pode, mas precisa de muito mais do que boas intenções e um PAC.

Para se compreender um dos limites do PAC veja-se o item transportes, onde o Programa faz a seguinte profissão de fé: "infraestrutura logística, envolvendo a construção e ampliação de rodovias, ferrovias, portos, aeroportos e hidrovias". ${ }^{60}$ Qualquer Plano Econômico que mereça esta denominação, neste país, contém algo semelhante. O Plano de Metas assim se posicionava: “investimentos estatais em infra-estrutura, principalmente transporte e energia elétrica". ${ }^{61}$

Tabela 15

Brasil

Plano de Metas: Previsão e resultados

1957-1961

\begin{tabular}{|l|c|c|c|}
\hline Especificação & Previsão & Realizado & \% \\
\hline Energia Elétrica (1000 Kw) & 2000 & 1650 & 82 \\
\hline Carvão (1000 toneladas). & 1000 & 230 & 23 \\
\hline Petróleo-Produção (1000 barris/dia) & 96 & 75 & 76 \\
\hline Petróleo-Refino (1000 barris/dia) & 200 & 52 & 26 \\
\hline Ferrovias (1000 km) & 3 & 17 & 138 \\
\hline Rodovias-Construção (1000 km) & 13 & 650 & 60 \\
\hline Rodovias-Pavimentação (1000 km) & 5 & 870 & 62 \\
\hline Aço (1000 toneladas) & 1100 & 133 & 78 \\
\hline Cimento (1000 toneladas) & 1400 & 75 & - \\
\hline Carros e Caminhões (1000 unidades) & 170 & 74 & - \\
\hline Nacionalização (carros) (\%) & 90 & & \\
\hline Nacionalização (caminhões) (\%) & 95 & & - \\
\hline
\end{tabular}

Fonte: ORENSTEIN \& SOCHACZEWSKI (1992): 180.

\footnotetext{
${ }^{60}$ Investimento em infra-estrutura. Disponível em: http://www.brasil.gov.br/pac/infra-estrutura. Acesso em 20 de dezembro de 2011.

61 ORENSTEIN \& SOCHACZEWSKI In: ABREU (Org.), 1992, pp. 171-195
} 
É evidente que o Plano de Metas era planejamento no melhor da tradição cepalina. Assemelhava-se bastante a outras experiências de planejamento, inclusive as recentes experiências asiáticas. Mesmo não envolvendo toda a economia, ou seja, mesmo sendo um planejamento setorial, as bases teóricas e conceituais do planejamento seguiam as normas e as técnicas da planificação soviética. ${ }^{62}$ Observando o Plano de Metas verifica-se, claramente, os

objetivos de se criar uma ampla malha de transporte e oferta abundante de energia. Foi planejada a construção de $13.000 \mathrm{~km}$ de rodovias e foram realizadas $17.000 \mathrm{~km}$. A tabela 15 mostra que se construiu apenas $1000 \mathrm{~km}$ de ferrovias, mas este fato denota uma decisão política (equivocada, mas consciente) e não um erro de planejamento. É verdade que o Plano de Metas aumentou os desequilíbrios regionais, internacionalizou excessivamente a economia e ampliou nossa dependência da economia norte-americana, mas criou uma infraestrutura e impulsos dinâmicos, vindos dos pontos de germinação ${ }^{63}$ e da demanda derivada ${ }^{64}$ que se propagaram pelas décadas de sessenta e setenta.

Sabiamente os formuladores do PAC chamaram-no de Programa e não de Plano. Em primeiro lugar, porque o nome planejamento poderia assustar os operadores do mercado, muito dos aliados políticos e poderia, ainda, ensejar idéias de que o partido político hegemônico no governo estivesse voltando no tempo, praticando alguma forma sutil de anacronismo ou abandonando seu "honesto" transformismo. Em segundo lugar, seria impróprio chamar o PAC de Plano, pois uma proposta de planejamento não dedicaria apenas $8,6 \%{ }^{65141}$ para infraestrutura logística que diz ser: "a construção e ampliação de rodovias, ferrovias, portos, aeroportos e hidrovias". Teria que se acrescentar estações, armazéns, estaleiros e diversas outras construções que acompanham qualquer expansão de estradas de transportes. Teria que se acrescentar pessoal em diversos níveis de formação. Realmente, 8,6\% para um Programa quadrienal é um valor irrisório, tanto é assim que a

\footnotetext{
${ }^{62}$ O Planejamento estatal começou a ser usado de forma ampla na planificação da economia da União Soviética. O primeiro plano qüinqüenal começou em 1929, em um momento histórico de muita gravidade para a economia capitalista mundial, ou seja, enquanto a URSS iniciava sua planificação econômica, o resto do mundo embarcava na Grande Depressão. De 1929 até 1939, enquanto as economias de mercado tentavam sair do fundo do poço, a produção industrial soviética cresceu de 5\% no total mundial em 1929 para 18\% em 1938. Fonte: HOBSBAWM, 1995

${ }^{63}$ Pontos de germinação são setores da economia que possuem potencial de crescimento, principalmente de induzir Demanda Derivada.

${ }^{64}$ Demanda Derivada é quando ocorre um aumento da demanda de bem derivado do crescimento da demanda por outro bem. Assim para se produzir mais navios ou vagões ferroviários é preciso produzir chapas de aço.
}

${ }^{65}$ Fonte: Tabela 14 
Ferrovia Transnordestina continua no papel.

Desse modo, realmente o segundo mandato do Presidente Luiz Inácio Lula da Silva não foi suficiente. Será certamente, necessário um segundo mandato para a Presidenta Dilma ou a volta triunfante (nos braços do povo ao estilo varguista) de Luiz Inácio Lula da Silva. Em suma: se o PSDB pensou em um "reinado" de pelo menos vinte anos, o Partido dos Trabalhadores pensa o mesmo. Isto porque muito do que o PT faz é a "passo de formiga".

Um dos problemas enfrentado pelo Programa de Aceleração do Crescimento - PAC foi o recorrente conflito entre os proponentes do crescimento econômico e os partidários das "finanças sadias". Não se estar usando de ironia ao se falar de "finanças sadias", mas se utiliza de um jargão de domínio público. Na verdade estes técnicos monetaristas representam os interesses do capital financeiro dentro do Estado. No caso em questão ficou evidente que os esforços do ministro Mantega $^{66}$ não foram suficientes para “colocar algumas idéias no seu devido lugar”, principalmente a ineficiência e inoportunidade da política de juros do Banco Central. Fato é que a redução da Selic vinha acontecendo a "passos de tartaruga", mas acontecia, quando o Copom interrompeu a descida na reunião de outubro de 2007. A decisão unilateral criou uma polêmica absurda que envolveu a própria autoridade do Presidente da República. ${ }^{67}$

O Banco Central não conseguia convencer da necessidade de suspender o processo de redução das taxas. A ata dizia explicitamente que "a dinâmica dos preços indica que a inflação tende a evoluir para a trajetória das metas". ${ }^{68145}$ Ou seja, nada naquele momento indicava ou sugeria uma elevação dos preços. Os motivos utilizados pelo Banco Central para manter as taxas de juros altas, normalmente, são pressão inflacionária por excesso de demanda ou problema de financiamento da dívida pública. A ata não apontava nenhum dos dois problemas e até os

${ }^{66}$ Em entrevista a Revista Época o ministro Guido Mantega nega ter enfrentado problemas com a dupla PalocciMeirelles e afirma que concorda com a política econômica de todo o período 2003-2011. Afirma que deixou claras as divergências com Meirelles, mas não conspirou contra o colega. Chega a ser suave quando fala de Palocci, mas se irrita quando lembrado de que só é rapidamente citado em apenas seis das 254 páginas do livro do desafeto. Parece que a institucionalização do Partido dos Trabalhadores foi completa. Fonte: ÉPOCA, No 713,16 de janeiro de 2012. pp. 32-49.

${ }^{67}$ De público o Presidente da República Luiz Inácio Lula da Silva e o Presidente do Banco Central Henrique Meirelles divergiram. O Presidente Luiz Inácio argumentava, com acerto, que já se estava ocupando toda capacidade instalada e que era necessário baixar os juros para estimular os empresários a expandir a capacidade, o que viria a auxiliar no controle inflacionário. Enquanto o Presidente do BACEN repetia a avaliação do Copom de que era tarefa do Banco Central agir sempre de maneira preventiva e prudencial.

${ }^{68}$ Comitê de Política Monetária. Sistema de metas para a inflação. Ata da $130^{\mathrm{a}}$ Reunião, p.1. Acesso em 27 de dezembro de 2011. 
descartavam. Onde estava o problema que gerava este movimento de política recessiva e contrária ao crescimento da economia?

O problema estava em um novo tecnicismo, que pode ser expresso da seguinte forma: segundo os gênios da economia financeira havia uma defasagem potencial entre as trajetórias da demanda e da oferta agregadas e isto poderia se transformar em pressão inflacionária futuramente. Dito de maneira, assim, pomposa e repetida “ad náusea” pela mídia transformava- se em argumento indiscutível. É a demanda que não converge para a oferta, estúpido! Pois é, os estúpidos aprenderam que a demanda e a oferta podem apresentar hiatos e a correção deles, em uma economia de mercado, é função do mecanismo de preços. Mas a pirotecnia monetarista diz que não. Diz que o equilíbrio entre demanda e oferta é garantido pela política monetária. Diz que é a taxa de juros que deve guiar as mercadorias nos labirintos dos mercados.

Duas questões saltam à vista neste episódio. Primeiro que os monetaristas só controlam inflação "baixando o pau na demanda", quando a inflação quase sempre é uma expressão de escassez de oferta. “Tão simples, tão óbvio, tão negligenciado”. Segundo é que havia uma ação aberta de boicote ao Programa de Aceleração do Crescimento - PAC, ou seja, o pouco que a parte desenvolvimentista do governo fazia para crescer no segundo mandato era combatido pela parte monetarista.

\section{Tabela 16}

Brasil

PAC - Balanço

Bilhões de reais

2007-2009

\begin{tabular}{|l|c|}
\hline Eixo de Planejamento & Realizado \\
\hline Logística (sobretudo transportes) & 40,5 \\
\hline Energia & 72,4 \\
\hline Infra-estrutura social & 144,0 \\
\hline Total do PAC & 256,9 \\
\hline
\end{tabular}

Fonte: Programa de Aceleração do Crescimento/PAC - Balanço de três anos.

Do que foi dito acima não se deve concluir que o PAC não tenha desempenhado nenhum papel no crescimento do Produto entre 2008 e 2010. O Programa deu importante contribuição como mecanismo keynesiano tradicional e já testado em diversas condições históricas. É evidente 
que gastos na ordem de 256 bilhões de reais ${ }^{69}$ reanimam a economia e é exatamente isto que o governo deve fazer sempre, apenas como cumprimento de dever. Aqui, também, o investimento privado aparece de imediato na forma de contratos públicos, para em seguida aparecer em outras formas.

A tabela 17 mostra que o número de famílias que foram atendidas pelo Programa BolsaFamília era de 3,6 milhões em 2003 e cresceu até atingir 12,4 milhões ${ }^{70}$ em 2009, o que correspondeu a um aumento de $245 \%$, trata-se de um aumento significativo, mesmo que se deva admitir que a base de partida era muito baixa. Em 2003 o referido programa pagou 600 milhões de reais, para pagar benefícios no montante de 12,5 bilhões de reais no ano de 2009. Trata-se de um aumento de mais de 20 vezes. Os gastos da Bolsa-Família entre 2007 e 2009 somam 32,6 bilhões de reais, o correspondente a $12,7 \%$ de todo desembolso do $\mathrm{PAC}^{71}$ no mesmo período. Corresponde, também, a $80,5 \%$ dos gastos do PAC $^{72}$ com logística.

\section{Tabela 17 \\ Brasil \\ Bolsa-Família \\ 2003-2009}

\begin{tabular}{|c|c|c|}
\hline Ano & $\begin{array}{c}\text { Bolsa Família (Famílias } \\
\text { Atendidas) (milhões de unidades) }\end{array}$ & $\begin{array}{c}\text { Bolsa Família (Pagamentos de } \\
\text { Benefícios) } \\
\text { (bilhões de reais) }\end{array}$ \\
\hline $\mathbf{2 0 0 3}$ & 3,6 & 0,6 \\
\hline $\mathbf{2 0 0 4}$ & 6,5 & 3,8 \\
\hline $\mathbf{2 0 0 5}$ & 8,7 & 5,8 \\
\hline $\mathbf{2 0 0 6}$ & 11,1 & 7,6 \\
\hline $\mathbf{2 0 0 7}$ & 11,1 & 9,2 \\
\hline $\mathbf{2 0 0 8}$ & 11,6 & 10,9 \\
\hline $\mathbf{2 0 0 9}$ & 12,4 & 12,5 \\
\hline
\end{tabular}

Fonte: Mercadante, 2010. Elaboração do Autor

\footnotetext{
${ }^{69}$ Fonte: tabela 16

${ }^{70}$ São 12,4 milhões de famílias que passam a consumir e acionam os mecanismos propagadores da demanda agregada.

${ }^{71}$ Fonte: tabela 16

72 Fonte: tabela 16
} 
A tabela 18 mostra que o Salário Mínimo acumulou variações reais positivas todos os anos dos dois mandatos do Presidente Luiz Inácio Lula da Silva, sendo que no período 2003- 2008 acumulou um total de 37,0\%; enquanto os Rendimentos Médios Reais cresciam apenas em 9,5\% no acumulado do período 2003-2008. Considerando-se a variação do PIB como Proxy para produtividade do trabalho, tem-se que o Produto acumulou 28,0\% de aumento. Conclusão: a produtividade foi de $28,0 \%,{ }^{73}$ os trabalhadores receberam $9,5 \%$ na média e o salário mínimo teve um ganho real de 37,0\%. ${ }^{74152}$ Um valor que reduz a defasagem histórica do mínimo, mas mantém a defasagem da maioria dos salários, principalmente do setor público.

\section{Tabela 18}

Brasil

Indicadores de Salários e Consumo das Famílias

(Variação Anual em \%)

2003-2008

\begin{tabular}{|c|c|c|c|c|}
\hline Ano & $\begin{array}{c}\text { Variação percentual } \\
\text { real do Salário } \\
\text { Mínimo }\end{array}$ & $\begin{array}{c}\text { Rendimentos } \\
\text { Médios Reais } \\
\mathbf{( \% )}\end{array}$ & $\begin{array}{c}\text { Massa Real de } \\
\text { Rendimentos } \\
(\%)\end{array}$ & $\begin{array}{c}\text { Consumo das } \\
\text { Famílias (\%) }\end{array}$ \\
\hline $\mathbf{2 0 0 3}$ & 1,23 & $-5,1$ & $-7,8$ & $-0,7$ \\
\hline $\mathbf{2 0 0 4}$ & 1,19 & 0,2 & 3,6 & 3,8 \\
\hline $\mathbf{2 0 0 5}$ & 8,23 & 2,4 & 5,7 & 4,5 \\
\hline $\mathbf{2 0 0 6}$ & 13,04 & 4,4 & 4,7 & 5,3 \\
\hline $\mathbf{2 0 0 7}$ & 5,10 & 3,6 & 6,4 & 6,3 \\
\hline $\mathbf{2 0 0 8}$ & 4,03 & 4,0 & 7,3 & 7,1 \\
\hline $\mathbf{2 0 0 9}$ & 5,79 & 2,4 & 2,3 & 4,1 \\
\hline
\end{tabular}

Fonte: IPEADATA apud Mercadante, 2010. Elaboração do Autor

No item distribuição de renda e redução da pobreza é preciso buscar a contextualização histórica. Os dados do IBGE, entre os anos sessenta e oitenta do século passado, indicam a seguinte evolução nos percentuais da pobreza no Brasil: Em 1960 havia 41,4\% de pobres, este número caiu para 39,3\% em 1970 e para 24,4\% em 1980. Com a forte recessão dos anos 80, ocorreu elevação na proporção de pobres: e, em 1983 o país voltava ao nível de 1960, com 41,9\%. A breve

\footnotetext{
${ }^{73}$ Fonte: Tabela 19

74 Tabela 18
} 
recuperação econômica do ano de 1986 associada ao forte crescimento do Plano Cruzado, fez cair rapidamente a proporção de pobres, neste ano ela desceu para 28,4\%. Nos anos seguintes, a escalada da inflação e a deterioração econômica, com os efeitos recessivos de planos antiinflacionários, elevaram de novo a taxa: 35,9 em 1987 e 39,3\% em 1988, voltando ao nível de 1970.

Segundo dados do IBGE em 1992, o percentual de pobres era de 35,16\%, caindo para um valor acima de 28,00\% no final da década de noventa e principio dos anos 2000. Em 2003 o Brasil tinha $13,7 \%$ de sua população vivendo em situação de indigência, enquanto $35 \%$ eram considerados pobres. Em 2008, a distribuição da renda já havia melhorado, de modo que nos cinco anos, que separam 2003 e 2008, os índices de indigência e pobreza foram reduzidos, respectivamente, a 6,6\% e 24,1\%. Estes dados indicam que 32 milhões de pessoas, o que equivale a mais de três vezes a população atual de Portugal e a $80 \%$ da população da vizinha Argentina, saíram da linha de pobreza.

A primeira vista pode-se pensar que este deslocamento para cima da população na escala de renda deve-se unicamente aos diversos programas sociais do atual governo, contudo, os dados indicam que houve um aumento significativo no volume agregado do emprego, ou seja, algo como oito milhões de novos postos no mercado de trabalho foi criado no período que vai de 2003 até 2009. (Jornal Valor Econômico de 29/12/2009)

Segundo Néri (2009) quando se analisa a redução total da desigualdade, verifica-se que a renda do trabalho assalariado responde por $66,86 \%$ na variação total, vindo a seguir os programas sociais com $17 \%$, enquanto os benefícios previdenciários explicam 15,72\%, o deixa um resíduo de menos de $1 \%$.

Quando se investiga a evolução da renda é preciso combinar os fluxos de renda com a trajetória temporal da pobreza, da desigualdade e das classes de renda. Apesar das limitações evidentes do conceito de classes de renda, é possível fazer uma adequada apreensão do movimento que leva segmentos da população dos níveis mais baixos de pobreza para níveis mais elevados de renda. Assim, a população é desagregada em quatro grupos de renda. 
Tabela 19

Variação na população por classes de rendimentos

Brasil

\begin{tabular}{|l|c|c|}
\hline Variação na população & $\mathbf{2 0 0 8 - 2 0 0 3}$ & $\mathbf{2 0 0 8 - 2 0 0 7}$ \\
\hline Classe E & $(19.458 .924,00)$ & $(3.798 .432,00)$ \\
\hline Classe D & $(1.485 .360,00)$ & $(899.594,00)$ \\
\hline Classe C & $25.890 .892,00$ & $5.285 .627,00$ \\
\hline Classe AB & $6.095 .662,00$ & $1.680 .397,00$ \\
\hline
\end{tabular}

Fonte: Néri (2009)

Nota: os valores entre parênteses indicam redução.

A classe de mais alta renda (acima de 4807,00 reais) incorpora entre 2003 e 2008, seis milhões de pessoas, de modo que esta camada atinge quase vinte milhões de pessoas. A segunda classe (entre 1115,00 reais e 4807,00) recebe 25,9 milhões de pessoas. Na terceira classe (entre 768,00 reais e 1115,00 reais) há uma redução de um milhão e meio de pessoas. Na última classe de renda (até 768,00 reais) há uma queda populacional de 19,4 milhões de pessoas.

A economia tradicional, mesmo a heterodoxa (ou keynesiana em particular) dá valor excessivo a chamada distribuição pessoal da renda que quase sempre ou "encobre" algumas formas disfarçadas de desigualdade ou "descobre" formas de políticas públicas compensatórias, mas insuficientes enquanto alternativa de inserção decente das populações pobres. A economia política, incluindo a economia kaleckiana preocupa-se fundamentalmente com a distribuição funcional da renda, ou seja, no quantum da renda nacional recebido pelos trabalhadores (salários), pelos capitalistas (lucros e aluguéis) e pelos rentistas (juros). Neste caso a parcela da renda apropriada pelos trabalhadores no período $2003-2009$ oscilou entre $31,5 \%$ e $29,3 \%{ }^{75}$, quando a absurda media histórica brasileira é de 30\%. Nos países do núcleo orgânico a parcela fica entre 60 e $70 \%$. Isto, logicamente não significa que há nenhuma inversão ou que os trabalhadores "estejam se apropriando" da acumulação, mas apenas que são em número muito mais elevado que os capitalistas. Outro fato para o qual a tabela 18 é absolutamente muda ${ }^{76}$ são os estupendos lucros bancários, para tanto se precisa da tabela 20.

\footnotetext{
${ }^{75}$ Fonte: IBGE. Contas Nacionais e Pesquisa Industrial Anual (PIA) Método de aferição: BARBOSA (2001)

${ }^{76}$ A tabela é muda, isto é, não fala, nem mesmo quando perguntada
} 
Tabela 20

Brasil

Participação dos Grandes

Bancos Privados (a) no PIB (\%)

Períodos selecionados

\begin{tabular}{|c|c|c|c|}
\hline Ano & $\mathbf{1 9 9 5 - 1 9 9 8}$ & $\mathbf{1 9 9 9 - 2 0 0 2}$ & $\mathbf{2 0 0 3 - 2 0 0 6}$ \\
\hline Ativo/PIB & 11,6 & 12,2 & 19,3 \\
\hline $\begin{array}{c}\text { Patrimônio Líquido/ } \\
\text { PIB }\end{array}$ & 1,4 & 1,9 & 2,2 \\
\hline
\end{tabular}

Fonte: Filgueiras \& Gonçalves (2007). Elaboração do Autor

Nota: (a) Inclui Bradesco, Unibanco e Itaú

A tabela 20 mostra a apropriação crescente do capital bancário sobre a Renda Nacional. No período 1995-1998 a relação Ativo/PIB era já de 11,6\% passando para um valor de 19,3\% no primeiro Lula enquanto a relação Patrimônio Líquido/PIB passou de 1,4\% no primeiro FHC para 2,2\% no primeiro Lula. A situação é sempre preocupante quando o capital financeiro passa da condição de "servo" obediente para "senhor" do capital produtivo.

A tabela 21 mostra que o consumo das famílias teve importante papel na formação da demanda agregada. O consumo teve um valor de - 0,39\% em 2003 cresceu para 3,80\% em 2007 e 3,27\% em 2008. Assim, no ano de 2008 o consumo contribui com 64,0\% para a composição do PIB $^{77155}$. O aumento do consumo deveu-se ao aumento de desembolsos de programas como a Bolsa-Família, do aumento real do salário mínimo em alguma medida do aumento da massa salarial.

A contribuição do consumo do governo tem sido muito discreta, enquanto as exportações caíram desde 2006. Em compensação a Formação Bruta de Capital Fixo apresentou uma ligeira reação desde 2006, ou seja, 1,69\% em 2006, 2,34\% em 2007 e 3,01\% em $2008^{78157}$, mas qualquer "vôo de águia" vai depender de uma expansão acentuada da Formação Bruta de Capital (investimento); ou em uma boa e insuperável linguagem e cultura marxista, tudo dependerá de um crescimento permanente e sustentado da Acumulação de Capital e que não ocorram novas restrições às exportações brasileiras.

\footnotetext{
77 Fonte: tabela 21

${ }^{78}$ Fonte: tabela 21
} 


\section{Tabela 21}

Brasil

Contribuição ao PIB

(Variação Anual em \%)

2003-2008

\begin{tabular}{|c|c|c|c|c|c|c|}
\hline Ano & $\begin{array}{c}\text { Consumo } \\
\text { das } \\
\text { Famílias }\end{array}$ & $\begin{array}{c}\text { Consumo } \\
\text { do } \\
\text { Governo }\end{array}$ & FBKF & Exportações & Importações & PIB \\
\hline $\mathbf{2 0 0 3}$ & $-0,39$ & 0,15 & $-0,28$ & 1,47 & 0,20 & 1,20 \\
\hline $\mathbf{2 0 0 4}$ & 2,31 & 0,79 & 1,87 & 2,29 & $-1,61$ & 5,70 \\
\hline $\mathbf{2 0 0 5}$ & 2,64 & 0,44 & $-42,00$ & 1,53 & $-1,06$ & 3,20 \\
\hline $\mathbf{2 0 0 6}$ & 3,06 & 0,51 & 1,69 & 0,76 & $-2,13$ & 4,00 \\
\hline $\mathbf{2 0 0 7}$ & 3,80 & 0,95 & 2,34 & 0,97 & $-2,38$ & 6,10 \\
\hline $\mathbf{2 0 0 8}$ & 3,27 & 1,12 & 3,01 & $-0,08$ & $-2,24$ & 5,10 \\
\hline
\end{tabular}

Fonte: IPEADATA apud Mercadante, 2010, p. 120. Elaboração do Autor

É exatamente pelo que foi apresentado acima que se pode considerar o período 2003-2010 como uma fase de recuperação nacional restringida, mesmo que se devam reconhecer vários avanços na sociedade brasileira. 


\section{Capítulo 4}

\section{Economia brasileira: comportamento da absorção externa e da incorporação tecnológica.}

Desde 1999 observa-se um movimento de expansão das exportações brasileiras. Contudo, é a partir de 2001 que a Balança Comercial começou a apresentar resultados positivos que levariam a mega-superávits maiores do que àqueles dos anos oitenta, chegando-se a atingir uma média de 32,5 bilhões de dólares entre 2002 e 2008.

O bom desempenho das exportações brasileiras esteve ligado à excelente performance da economia mundial a partir de 2003. O aumento da demanda mundial eleva a demanda de commodities e conseqüentemente seus preços. Isto não significa que a economia brasileira apenas se adaptou aos movimentos dos preços. A leitura da tabela 38 mostra que os produtos básicos e os produtos semimanufaturados tiveram variação mais intensa dos preços, enquanto os manufaturados foram guiados por maior variação no quantum ( $72 \%$ contra $31 \%$ ). Não se pode, então, afirmar que houve uma adaptação totalmente passiva da economia brasileira ao ciclo expansivo mundial, inclusive porque a variação do quantum das exportações totais foi de $56 \%$, ou seja, $10 \%$ superior ao efeito-preço (46\%). Contudo, os fortes efeitos dos preços para as categorias dos básicos (63\%) e semimanufaturados (68\%) indicam uma tendência à reprimarização.

\section{Tabela 22}

Brasil

Evolução das Exportações por fator agregado

2002-2006 (Base: 1996)

\begin{tabular}{|c|c|c|c|c|c|c|c|c|}
\hline Período & \multicolumn{2}{|c|}{$\begin{array}{c}\text { Exportações } \\
\text { Totais }\end{array}$} & \multicolumn{2}{c|}{ Produtos básicos } & \multicolumn{2}{c|}{$\begin{array}{c}\text { Produtos } \\
\text { semimanufaturados }\end{array}$} & \multicolumn{2}{c|}{$\begin{array}{c}\text { Produtos } \\
\text { manufaturados }\end{array}$} \\
\hline & Preços & Quantum & Preços & Quantum & Preços & Quantum & Preços & Quantum \\
\hline $\mathbf{2 0 0 2}$ & 77,9 & 162,3 & 65,5 & 217,6 & 74,9 & 139,0 & 82,9 & 150,8 \\
\hline $\mathbf{2 0 0 3}$ & 81,5 & 187,8 & 72,3 & 246,2 & 83,4 & 152,5 & 82,4 & 182,3 \\
\hline $\mathbf{2 0 0 4}$ & 90,3 & 223,8 & 85,6 & 280,1 & 95,5 & 163,4 & 87,2 & 229,8 \\
\hline $\mathbf{2 0 0 5}$ & 101,3 & 244,7 & 97,8 & 298,5 & 106,8 & 173,6 & 96,7 & 255,1 \\
\hline $\mathbf{2 0 0 6}$ & 113,9 & 252,8 & 106,9 & 316,5 & 126,1 & 179,7 & 108,6 & 260,5 \\
\hline Variação & $\mathbf{4 6 \%}$ & $\mathbf{5 6 \%}$ & $\mathbf{6 3 \%}$ & $\mathbf{4 5 \%}$ & $\mathbf{6 8 \%}$ & $\mathbf{2 9 \%}$ & $\mathbf{3 1 \%}$ & $\mathbf{7 2 \%}$ \\
\hline
\end{tabular}

Fonte: IPEADATA 
A tabela 23 mostra dados importantes sobre o comércio exterior no período de governo do Presidente Luiz Inácio Lula da Silva. Observa-se que as exportações agrícolas (XA) mantêm uma superioridade muito alta em relação às importações agrícolas (MA), de forma que a razão XA/MA chega a atingir 8,55 vezes. Três conclusões se impõem: (a) a auto-suficiência brasileira na produção agrícola; (b) o alto volume e receita das exportações não-industriais; (c) os mega- superávits obtidos na comercialização de produtos agrícolas.

Tabela 23

Brasil

Balança Comercial (Total e Agrícola)

(Bilhões de Dólares)

2003-2009

\begin{tabular}{|c|c|c|c|c|}
\hline Ano & $\begin{array}{c}\text { Exportações } \\
\text { Agrícolas (XA) }\end{array}$ & $\begin{array}{c}\text { Importações } \\
\text { Agrícolas (MA) }\end{array}$ & $\begin{array}{c}\text { Razão } \\
\text { XA/MA }\end{array}$ & Saldo Comercial \\
\hline $\mathbf{2 0 0 3}$ & 30,6 & 4,7 & 6,51 & 25,9 \\
\hline $\mathbf{2 0 0 4}$ & 39,0 & 4,8 & 8,12 & 34,2 \\
\hline $\mathbf{2 0 0 5}$ & 43,6 & 5,1 & 8,55 & 38,5 \\
\hline $\mathbf{2 0 0 6}$ & 49,5 & 6,7 & 7,45 & 42,8 \\
\hline $\mathbf{2 0 0 7}$ & 58,4 & 8,7 & 6,71 & 49,7 \\
\hline $\mathbf{2 0 0 8}$ & 71,8 & 11,8 & 6,08 & 60,0 \\
\hline $\mathbf{2 0 0 9}$ & 64,8 & 9,8 & 6,61 & 54,9 \\
\hline $\mathbf{A n o}$ & Exportações & Importações & Razão & Saldo Comercial \\
\hline $\mathbf{2 0 0 3}$ & 73,2 & 48,3 & 1,51 & 24,9 \\
\hline $\mathbf{2 0 0 4}$ & 96,7 & 62,9 & 1,54 & 33,8 \\
\hline $\mathbf{2 0 0 5}$ & 118,5 & 73,6 & 1,61 & 44,9 \\
\hline $\mathbf{2 0 0 6}$ & 137,8 & 91,3 & 1,51 & 46,5 \\
\hline $\mathbf{2 0 0 7}$ & 160,6 & 120,6 & 1,33 & 40,0 \\
\hline $\mathbf{2 0 0 8}$ & 197,9 & 173,1 & 1,14 & 24,8 \\
\hline $\mathbf{2 0 0 9}$ & 152,2 & 126,9 & 1,20 & 25,3 \\
\hline
\end{tabular}

Fontes: Funcex e BCB apud Mercadante, 2010, pp. 80-81 e Ministério da Agricultura, Pecuária e Abastecimento apud Mercadante, 2010, p. 168. Elaboração do Autor. 
Quando se observa a parte inferior da tabela 23, relativa ao comércio externo total percebe-se que a razão XT/MT que já foi de 1,61 indicando que as exportações brasileiras pagavam as importações com um saldo de $60 \%$, acusou uma queda acentuada para $1,14 \mathrm{em}$ 2008 e 1,20 em $2009^{79}$. São dados preocupantes quando se pensa em desenvolvimento econômico, pois aponta para a possibilidade de um processo de reprimarização da economia. ${ }^{80}$

Outra informação importante contida na tabela 23 é de que o saldo comercial agrícola superou o saldo comercial total em cinco anos da série, perdendo apenas em 2005 e 2006 por pequena diferença, isto novamente indicaria uma forte predominância de bens primários na pauta e conseguintemente uma tendência à reprimarização da economia brasileira.

Uma das questões que muito se discute (Bresser-Pereira, 2007 e 2010) é do risco do Brasil sofrer algum ataque da "doença holandesa" ${ }^{81}$, apesar do risco maior ser a "euforia chinesa" $"$. Volta-se às duas questões mais abaixo.

A tabela 24 confirma através da razão exportações agrícolas/exportações totais (XA/XT) um peso de 36\% no período 2005-2008 a 42\% em 2009 das exportações agrícolas na pauta. Pode-se dizer, então, que os dados disponíveis quando cruzados indicam que os

${ }^{79}$ As razões 1,14 e 1,20 correspondem a saldo de quase metade daquele obtido em 2005, ou seja, 25 bilhões de dólares.

${ }^{80}$ Por reprimarização da economia se entende o aumento relativo das receitas de exportação (preço $\mathrm{x}$ quantum) de bens primários frente ao declínio negativo das receitas de exportação de bens industriais. É uma discussão que deve ser feita com cuidado e rigor. Deve ser devidamente contextualizada. Por sua vez, não é um problema apenas de oferta, mas também de demanda (aqui, também, a demanda comanda a oferta), é claro que para exportar bens primários o país precisa tê-los ou ter os recursos necessários para produzi-los.

${ }^{81}$ É um termo geral que se aplica às situações de forte apreciação cambial decorrentes de grandes saldos na balança comercial, que são causadas, principalmente, pelo crescimento extraordinário da quantidade exportada ou do preço de commodities de exportação. A origem do nome deve-se a um fenômeno ocorrido na Holanda quando da descoberta de grandes reservas de gás natural. O aumento da exportação do produto causou forte apreciação da moeda doméstica, perda de competitividade industrial e conseqüente desindustrialização

${ }^{82}$ O PIB chinês cresceu a uma média de $10 \%$ entre 1999 e 2008, segundo informação do Fundo Monetário Internacional. Fonte: www.imf.org 
bens primários ou os semimanufaturados estão aumentando suas participações na receita.

\section{Tabela 24}

Brasil

Razão das Exportações

Agrícolas (XA) Sobre as

Exportações Totais (XT) em (\%)

2003-2009

\begin{tabular}{|l|c|}
\hline Ano & $\begin{array}{c}\text { Exportações Agrícolas (XA)/ Exportações Totais } \\
\text { (XT) }\end{array}$ \\
\hline $\mathbf{2 0 0 3}$ & 41,80 \\
\hline $\mathbf{2 0 0 4}$ & 40,33 \\
\hline $\mathbf{2 0 0 5}$ & 36,79 \\
\hline $\mathbf{2 0 0 6}$ & 35,92 \\
\hline $\mathbf{2 0 0 7}$ & 36,36 \\
\hline $\mathbf{2 0 0 8}$ & 36,28 \\
\hline $\mathbf{2 0 0 9}$ & 42,57 \\
\hline
\end{tabular}

Fontes: Tabela 23

A tabela 25 retirada de Mercadante (2010) mostra as principais mercadorias exportáveis brasileiras. São dez produtos mais um item denominado de "demais produtos" correspondente a 7,6\% das exportações brasileiras em 2008. Todos os dez produtos têm origem agropecuária, mesmo que alguns possam indicar processos de semimanufaturados ou até manufaturado, não há como observar agregação de alto valor nos citados produtos. Não há como supor muito valor agregado em "cereais, farinhas e preparações” e mesmo que houvesse seu peso é de 3,1\%, enquanto "fibras e produtos têxteis" apresentam-se com percentual de $2,2 \%$. O "complexo da soja" representa $25 \%$, ou seja, $1 / 4$ das exportações brasileiras. Os cinco primeiros itens da pauta correspondem a $76 \%$ do total, ou seja, $3 / 4$ das exportações. O café, que ajudou tanto, mas também criou inumeráveis problemas, ainda contribui com $6,6 \%$ e é o quinto produto da pauta.

Segundo Mercadante (2010, p. 169) os setores "complexo da soja", "carnes" e "sucroalcooleiro" contribuíram com $75 \%$ do aumento das exportações brasileiras no período de 2003 a 2008. Por sua vez, a economia brasileira ocupa a primeira posição 
mundial na produção de açúcar, café e suco de laranja. Nesta mesma direção somos os principais fornecedores mundiais dos três produtos citados acima acrescidos de mais dois: "carne bovina" e "carne e aves".

Tabela 25

Brasil

Participação dos Principais

Exportáveis 2008

\begin{tabular}{|l|c|c|}
\hline Principais Produtos & Valor (US\$) & (\%) \\
\hline Complexo da Soja & 17.980 .184 .191 & 25,0 \\
\hline Carnes & 14.545 .483 .709 & 20,3 \\
\hline Produtos florestais & 9.326 .148 .932 & 13,0 \\
\hline Complexo Sucroalcooleiro & 7.873 .074 .318 & 11,0 \\
\hline Café & 4.763 .068 .651 & 6,6 \\
\hline Couro, Produtos de Couro, e peleteria & 3.140 .208 .311 & 4,4 \\
\hline Fumo e seus produtos & 2.752 .032 .482 & 3,8 \\
\hline Cereais, farinhas e preparações & 2.206 .966 .200 & 3,1 \\
\hline Sucos de frutas & 2.151 .782 .905 & 3,0 \\
\hline Fibras e produtos têxteis & 1.587 .383 .802 & 2,2 \\
\hline Demais produtos & 5.480 .133 .717 & 7,6 \\
\hline Total & $\mathbf{7 1 . 8 0 6 . 4 6 7 . 2 1 8}$ & $\mathbf{1 0 0 , 0}$ \\
\hline
\end{tabular}

Fonte: SECEX/MDCI apud Mercadante, 2010, p. 169

Resta lembrar que parte importante da dinâmica mundial recente esteve ligada, podese dizer dependente, da forte expansão da economia chinesa. Aquela economia cresceu num impulso tão forte que para sustentá-lo foi necessário uma elevação permanente da demanda por produtos básicos e semimanufaturados, especialmente minerais metálicos e grãos. É a elevação dos preços destes produtos aliada a uma procura sempre crescente que se pode chamar de "euforia chinesa". Países ricos em bens primários, grandes fornecedores de commodities, como o Brasil são automaticamente arrastados pela "euforia chinesa", tornando-se, também, por contágio, “eufóricos".

Assim, pode-se creditar ao bom desempenho mundial, particularmente ao 
excelente crescimento chinês, os ganhos de exportação da economia brasileira, o que também indica tendência à reprimarização.

A própria experiência do período 2003-2008 mostra a existências de movimentos complexos. Observa-se que a taxa de câmbio tende à sobrevalorização devido aos saldos positivos na Balança Comercial e da entrada de capitais externos em função do diferencial entre as taxas de juros internas e as externas, o que deveria ser respondido, numa ótica linear, com acomodações da Balança Comercial pela perda de competitividade. Entretanto, a apreciação cambial foi contrabalanceada pelo aumento dos preços e das quantidades.

Tabela 26

Brasil

Estrutura das Exportações Brasileiras Por Segmentos de Intensidade Tecnológica (Totais e de Produtos Industriais) (Percentual)

\begin{tabular}{|l|c|c|c|}
\hline $\begin{array}{l}\text { Exportações Brasileiras de Produtos } \\
\text { Industriais }\end{array}$ & $\mathbf{2 0 0 2}$ & $\mathbf{2 0 0 8}$ & $\begin{array}{c}\text { Variação } \\
\mathbf{2 0 0 8} / \mathbf{2 0 0 2}\end{array}$ \\
\hline Alta tecnologia & 12,20 & 8,11 & $-33,52$ \\
\hline Baixa tecnologia & 39,32 & 36,22 & $-7,88$ \\
\hline Média-alta tecnologia & 26,59 & 28,28 & 6,36 \\
\hline Média-baixa tecnologia & 21,89 & 27,39 & 25,13 \\
\hline Total & 100,00 & 100,00 & - \\
\hline Exportações Brasileiras Totais & $\mathbf{2 0 0 2}$ & $\mathbf{2 0 0 8}$ & Variação \\
\hline Indústria de alta tecnologia & 9,83 & 5,81 & $\mathbf{2 0 0 8 / 2 0 0 2}$ \\
\hline Indústria de baixa tecnologia & 31,70 & 25,96 & $-40,89$ \\
\hline Indústria de média-alta tecnologia & 21,43 & 20,27 & $-5,40$ \\
\hline Indústria de média-baixa tecnologia & 17,64 & 19,64 & 11,33 \\
\hline Produtos Não-industriais & 19,40 & 28,32 & 45,98 \\
\hline Total & 100,00 & 100,00 & - \\
\hline
\end{tabular}

Fontes: MDIC apud Mercadante, 2010, pp. 163 e IBRE/FGV apud Mercadante, 2010, pp. 162. Elaboração do Autor

Quando se examinam os dados de exportação quanto ao grau de intensidade 
tecnológica dos produtos percebem-se evidências de movimentos de reprimarização, mesmo que incipientes e de ausência de upgrade das exportações dos itens industriais. A tabela 26 mostra que quando se observa a parte superior da tabela, os produtos industriais de alta tecnologia sofrem uma queda de participação na pauta de $33,52 \%$, enquanto os produtos industriais de baixa tecnologia caem em $7,88 \%$. Por outro lado, os produtos industriais de média tecnologia aumentam sua participação em 31,94\%

$\mathrm{Na}$ investigação das exportações totais, parte inferior da tabela observa-se que as exportações industriais de alta tecnologia sofrem uma queda de $40,89 \%$, enquanto as exportações industriais de baixa tecnologia, também, caem em 18,10\%. As exportações industriais de média- alta tecnologia decrescem de 5,40\%, enquanto as exportações industriais de média-baixa tecnologia, próprias da Segunda Onda crescem de 11,33\%. Finalmente, mas não em importância, os produtos não-industriais apresentam uma variação positiva de $45,98 \%$ superior a qualquer outra variação mostrada na tabela 26 , seja positiva ou negativa. 


\section{Capítulo 5}

\section{A economia brasileira na década atual ou crônica de um desastre anunciado}

\section{A questão da acumulação de capital no período mais recente}

A questão relevante é que a variável-chave do desenvolvimento capitalista é a acumulação de capital, comumente denominada de investimento ou nas contas nacionais de Formação Bruta de Capital Fixo (FBKF). A tabela 1 apresenta dados que permitem uma análise de longa duração.

Tabela 27

Brasil

Taxa de Investimento (\% do PIB)

(Média Móvel de Quatro Anos)

\begin{tabular}{|c|c|c|c|c|c|c|}
\hline Ano & $\mathbf{1 9 6 5}$ & $\mathbf{1 9 8 0}$ & $\mathbf{1 9 9 0}$ & $\mathbf{2 0 0 0}$ & $\mathbf{2 0 1 0}$ & $\mathbf{2 0 1 9}$ \\
\hline $\mathbf{( \% ~ I / P I B )}$ & 15,5 & 22,6 & 23,8 & 18,2 & 19,3 & 15,5 \\
\hline
\end{tabular}

Fonte: IBRE/FGV - Elaboração do Autor

O IBRE/FGV (Instituto Brasileiro de Economia da Fundação Getúlio Vargas) realizou um estudo de pouco mais de meio século, atravessando os Governos dos militares, de Sarney, de Collor, de FHC, de Lula, de Dilma, de Temer e o primeiros meses de Bolsonaro e concluiu que a economia brasileira atingiu o fundo do poço, a saber, a taxa de investimento é a menor dos últimos 50 anos. Com os níveis de acumulação de Capital abaixo de $20 \%$ do PIB por anos seguidos falar em recessão é eufemismo dos economistas burgueses, a economia entrou em depressão e não sairá tão cedo. Falar em baixo nível de acumulação de capital é falar de gastos reduzidos com máquinas, equipamentos, construção civil e compra de força de trabalho. O dado que aparece em 2019 de 15,5\% é a média dos cinco últimos anos, 2015-2019; enquanto a média 2006-2010 ficou em 19,3\%.

Diferentemente do que dizem muitos e pensam outros, as políticas de recessão induzida não resolvem o problema, antes o agravam. Com a elevada ociosidade da 
capacidade, não há estímulo para novos investimentos, a queda no investimento público possui dois efeitos reduz o produto diretamente e indiretamente, na medida que desestimula a acumulação privada.

Tabela 28

Brasil

Formação Bruta de Capital Fixo

Variação anual (\%)

\begin{tabular}{|l|c|}
\hline Ano & (\%) \\
\hline 2003 & $-4,0$ \\
\hline 2004 & 8,5 \\
\hline 2005 & 2,0 \\
\hline 2006 & 6,7 \\
\hline 2007 & 12,0 \\
\hline 2008 & 12,3 \\
\hline 2009 & $-2,1$ \\
\hline 2010 & 17,9 \\
\hline 2011 & 6,7 \\
\hline 2012 & 0,8 \\
\hline 2013 & 5,8 \\
\hline 2014 & $-4,5$ \\
\hline 2015 & $-13,9$ \\
\hline 2016 & $-10,2$ \\
\hline 2017 & $-3,0$ \\
\hline 2018 & $-4,3$ \\
\hline
\end{tabular}

Fonte: IBGE - Elaboração do Autor 
Como mostrado na Tabela 28, a Formação Bruta de Capital Fixo no período total de 2003 a 2019 apresenta muita oscilação, mas é fato que de 2004 a 2010 cresce chegando a 17,9 com dois valores negativos para a série, isto é, - 4,0 para 2003 e - 2,1 para 2009, neste último caso tratou de um primeiro espasmo da crise norte-americana de 2008. Cabe observar que é no período de 2006 a 2010, denominado do segundo Lula que a economia tem seu melhor desempenho. A Formação Bruta de Capital Fixo atinge seu melhor desempenho. A FBKF de 2010 a 2019 apresenta um comportamento positivo até 2013, apesar de declinante e um comportamento negativo de 2014 a 2019. Além da crise estrutural de 2008, as políticas implementadas pelos operadores brasileiros foram fortemente recessivas. Desde a segunda Dilma. A mudança do padrão anterior com a aceitação da Agenda FIESP afundou a economia.

A situação econômica favorável possibilitou, durante o período de 2005/2006 a 2010/2011, um crescimento razoável com aumentos reais do salário-mínimo, dos salários em geral e as políticas compensatórias do Bolsa Família, melhorando a renda dos trabalhadores e das famílias mais pobres. O mercado interno efetivamente é o responsável pelo crescimento, desde que se entenda que o investimento sustentava o impulso positivo. Se a política econômica do segundo Lula era possível de ser estendida ou não é difícil provar por métodos econométricos, mas a razão histórica mostra que o limite do capital é o próprio capital, a saber, quando a taxa de lucro cai o ajuste deve ser realizado contra os trabalhadores 


\section{Tabela 29}

Brasil

Evolução do PIB e da Inflação

2003-2019

\begin{tabular}{|c|c|c|c|c|}
\hline Ano & PIB & $\begin{array}{l}\text { PIB per } \\
\text { capita }\end{array}$ & IPCA & $\begin{array}{c}\text { IPC } \\
\text { (IGP- } \\
\text { DI) }\end{array}$ \\
\hline 2003 & 1,1 & $-0,1$ & - & 7,67 \\
\hline 2004 & 5,8 & 4,5 & - & 12,13 \\
\hline 2005 & 3,2 & 2,0 & 5,69 & 4,93 \\
\hline 2006 & 4,0 & 2,8 & 3,14 & 2,05 \\
\hline 2007 & 6,1 & 5,0 & 4,46 & 4,60 \\
\hline 2008 & 5,1 & 4,0 & 5,90 & 6,07 \\
\hline 2009 & $-0,1$ & $-1,1$ & 4,31 & 3,95 \\
\hline 2010 & 7,5 & 6,5 & 5,91 & 6,24 \\
\hline 2011 & 4,0 & 3,1 & 6,50 & 6,36 \\
\hline 2012 & 1,9 & 1,0 & 5,84 & 5,74 \\
\hline 2013 & 3,0 & 2,1 & 5,91 & 5,63 \\
\hline 2014 & 0,5 & $-0,3$ & 6,41 & 6,87 \\
\hline 2015 & $-3,5$ & $-4,4$ & 10,67 & 10,53 \\
\hline 2016 & $-3,3$ & $-4,1$ & 6,29 & 6,18 \\
\hline 2017 & 1,1 & 0,3 & 2,95 & 3,23 \\
\hline 2018 & 1,1 & 0,3 & 3,75 & 4,32 \\
\hline 2019 & 0,5 & $-0,2$ & 3,22 & 3,87 \\
\hline \multicolumn{2}{|c|}{ Média PIB 2003-2010 } & \multicolumn{3}{|c|}{4,10} \\
\hline \multicolumn{2}{|c|}{ Média PIB 2006-2010 } & \multicolumn{3}{|c|}{4,50} \\
\hline \multicolumn{2}{|c|}{ Média PIB 2011-2019 } & \multicolumn{3}{|c|}{0,50} \\
\hline \multicolumn{2}{|c|}{ Média PIB 2016-2019 } & \multicolumn{3}{|c|}{$-0,40$} \\
\hline \multicolumn{2}{|c|}{ Média PIB pc 2003-2010 } & \multicolumn{3}{|c|}{2,95} \\
\hline \multicolumn{2}{|c|}{ Média PIB pc 2006-2010 } & \multicolumn{3}{|c|}{3,44} \\
\hline \multicolumn{2}{|c|}{ Média PIB pc 2011-2019 } & \multicolumn{3}{|c|}{$-0,24$} \\
\hline \multicolumn{2}{|c|}{ Média PIB pc 2016-2019 } & \multicolumn{3}{|c|}{$-0,90$} \\
\hline
\end{tabular}

Fonte: Banco Central do Brasil. Elaboração do Autor

A Tabela 29 permite conclusões que corroboram o que foi argumentado acima. O comportamento do PIB, assim como do PIB per capita foram extremamente erráticos em todo o grande período que vai de 2011 a 2019. De 2003 a 2010 ocorreu um crescimento de 4,10 e de 2006 a 2010 este valor sobe para 4,50. Neste segundo subperíodo a economia destrava através do mercado interno. A análise do período 2011-2019 indica um pífio 0,5; enquanto o subperíodo depois do golpe de 2016 projeta uma queda de 0,4. 


\section{Tabela 30 \\ Brasil \\ Contas Nacionais \\ 2013-2019 \\ Base 1995 $=100$}

\begin{tabular}{|c|c|c|c|c|c|c|}
\hline Período & $\begin{array}{c}\text { PIB a } \\
\text { preços de } \\
\text { mercado }\end{array}$ & $\begin{array}{c}\text { Consumo } \\
\text { fas } \\
\text { Famílias }\end{array}$ & $\begin{array}{c}\text { Consumo } \\
\text { do } \\
\text { Governo }\end{array}$ & $\begin{array}{c}\text { Formação } \\
\text { Bruta de } \\
\text { Capital } \\
\text { Fixo }\end{array}$ & Exportação & Importação \\
\hline $\mathbf{2 0 1 3}$ & 174,25 & 180,47 & 149,21 & 195,54 & 272,90 & 288,80 \\
\hline $\mathbf{2 0 1 4}$ & 175,14 & 184,59 & 150,37 & 187,21 & 263,37 & 282,27 \\
\hline $\mathbf{2 0 1 5}$ & 168,92 & 178,60 & 147,27 & 161,34 & 287,17 & 242,18 \\
\hline $\mathbf{2 0 1 6}$ & 163,24 & 171,66 & 148,54 & 141,56 & 289,65 & 217,13 \\
\hline $\mathbf{2 0 1 7}$ & 165,24 & 173,99 & 147,28 & 138,02 & 304,84 & 227,96 \\
\hline $\mathbf{2 0 1 8}$ & 166,92 & 176,40 & 147,24 & 143,72 & 317,18 & 247,33 \\
\hline $\mathbf{2 0 1 9}$ & 165,00 & 175,03 & 145,00 & 138,00 & 310,00 & 246,00 \\
\hline
\end{tabular}

Fonte: IBGE/Banco Central do Brasil - Elaboração do Autor

A tabela 30 fornece mais informações obtidas das Contas Nacionais. A composição do PIB é dada pelo Consumo das famílias, pelo Consumo do governo, pela FBKF e pelo Saldo de exportação. O produto se reduz quase monotonicamente, acusando uma perda de $5,3 \%$. Da mesma forma entram em queda os consumos privado e do governo, enquanto o saldo exportador chega a negativar-se alguns anos. Contudo, o fato que requer atenção é a queda livre da Formação Bruta de Capital Fixo em 25,8\%. Esses dados permitem concluir que os problemas da economia brasileira estão além do conceito de recessão e de baixo crescimento, trata-se de uma estrutura econômica deprimida e com “entraves" à acumulação de capital produtivo. Trata-se, pois, de uma crise estrutural do capitalismo nacional. Até que ponto a dominância financeira e os graus de liberdade dos capitalistas em torno dos ganhos especulativos explicam o próprio desprezo pela universalidade da mercadoria é, ainda, uma questão em aberto. Ou seja, a burguesia não acumula, produtivamente, porque não pode ou porque não deseja?

O gráfico 3 permite uma melhor visualização, pois as mesmas séries da tabela 4 estão 
dessazonalizadas. Assim, a lenta reversão da acumulação de capital tem início entre o segundo e o terceiro trimestre de 2013, acentua-se no terceiro trimestre de 2014 decrescendo mais que o produto e os consumos privado e do governo. No final de 2015 e começo de 2016 esta variável-chave cai além da queda do consumo familiar, permanecendo nessa posição depressiva desde então.

\section{Gráfico 3 \\ Brasil}

Contas Nacionais

2013-2019

Séries dessazonalizadas

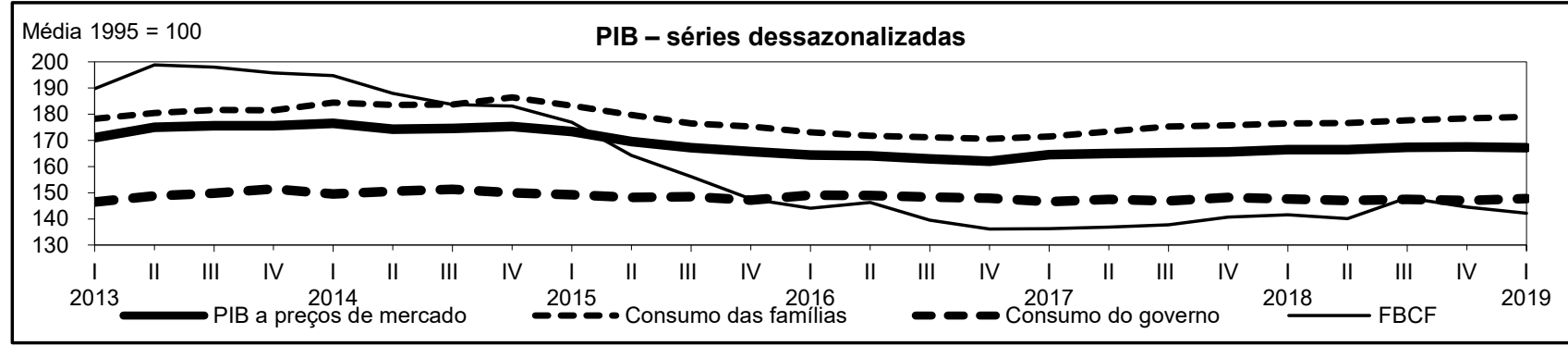

Fonte: IBGE/Banco Central do Brasil

\section{Algumas comparações internacionais}

As tendências depressivas na economia brasileira persistem desde a reversão do ciclo expansivo do II PND. Pode-se observar alguns fatos relevantes na Tabela 31, quando desde a década de oitenta a taxa de acumulação de capital no Brasil não ultrapassa a barreira dos $20 \%$. Nos governos petistas registrou valores poucos maiores de $18 \%$ com viés de queda a partir de 2014. Nas décadas de 2001-2010 a marca foi de 18,2\% e na de 2011-2018 de 18,3\%. A projeção total 2011-2020 indica queda para 17,9\%.

Frente ao desempenho da economia brasileira, a economia capitalista mundial cresce a taxas de $25 \%$ na média e as economias chamadas de emergentes, na qual o Brasil se insere com viés de baixa chegou a aumentar o investimento acima de 30\% Chegando a 32,5\% no último período, com projeção idêntica para toda a década. Mesmo a junção da América Latina com a região do Caribe cresceu num ritmo em torno de $20 \%$. 
Tabela 31

Taxas de investimento

(\%PIB)

Décadas

\begin{tabular}{|c|c|c|c|c|c|}
\hline Período/Região & $\mathbf{1 9 8 1 - 1 9 9 0}$ & $\mathbf{1 9 9 1 - 2 0 0 0}$ & $\mathbf{2 0 0 1 - 2 0 1 0}$ & $\mathbf{2 0 1 1 - 2 0 1 8}$ & $\begin{array}{c}\text { 2011-2020 } \\
\text { (1) }\end{array}$ \\
\hline Mundo & 25,0 & 24,1 & 23,9 & 25,7 & 25,8 \\
\hline $\begin{array}{c}\text { Economias } \\
\text { Emergentes }\end{array}$ & 25,0 & 25,2 & 28,1 & 32,5 & 32,5 \\
\hline AL + Caribe & 20,4 & 20,4 & 20,6 & 20,8 & 20,5 \\
\hline Brasil & 18,8 & 19,5 & 18,2 & 18,3 & 17,9 \\
\hline
\end{tabular}

Fontes: IBGE/FMI

Nota (1) Projeções WEO/FMI (abril de 2019)

Um dos Relatórios mais importantes do Fundo Monetário Internacional (FMI), o World Economic Outlook aponta que para 2018, 90\% dos países, isto é, 152 em 172 apresentaram uma taxa de investimento maior do que a brasileira. Todos, com a discutível exceção da Grécia e do Uruguai são países periféricos e de baixíssima industrialização, diferentemente do Brasil semiperiférico e relativamente industrializado. Mesmo o Uruguai, a Bósnia-Herzegovina e Macau empatam com o Brasil na faixa de 15,0\%.

A leitura da Tabela 32 ajuda a entender a gravidade do caso brasileiro. Na década de oitenta $71 \%$ dos países tiveram taxa de investimento superior ao Brasil. Nos anos noventa esse percentual ficou em 70,0\%. Na primeira década do atual século o percentual subiu para $83,0 \%$. Na década atual caiu levemente para 79,0\%. O resultado é uma média histórica, em quarenta anos de 76,0\% países com taxa de investimento acima da brasileira. Até que ponto há uma ameaça a condição semiperiférica do Brasil? 
Tabela 32

Proporção de Países com Taxas de Investimento

(\%PIB) maior do que a vigente no Brasil

Décadas

\begin{tabular}{|c|c|c|c|c|}
\hline 1981-1990 & 1991-2000 & 2001-2010 & 2011-2018 & 2011-2020 (1) \\
\hline 71 & 70 & 83 & 79 & 81 \\
\hline
\end{tabular}

Fontes: IBGE/FMI

Nota (1) Projeções WEO/FMI (abril de 2019)

Como mostrado na Tabela 33 o crescimento da taxa de investimento no mundo ficou, na média, em 2018, em 26,2\%, um pouco mais de 10,0\%“do que o Brasil. Na comparação com as Economias Emergentes, estas apresentam um resultado de 32,8\%, logo mais que o dobro brasileiro. O conjunto da América Latina mais Caribe representa uma média 4,0\% maior do que a brasileira.

\begin{tabular}{c} 
Tabela 33 \\
Taxas de investimento \\
$\begin{array}{c}\text { (\%PIB) } \\
\mathbf{2 0 1 8}\end{array}$ \\
\begin{tabular}{|c|c|}
\hline Mundo & 26,2 \\
\hline $\begin{array}{c}\text { Economias } \\
\text { Emergentes }\end{array}$ & 32,8 \\
\hline AL + Caribe & 19,6 \\
\hline Brasil & 15,8 \\
\hline
\end{tabular} \\
\hline
\end{tabular}

A análise da Tabela 34 nas quatros décadas mostra que o Brasil sempre esteve investindo abaixo destes outros países representativos da América Latina. A diferença chega a ser importante quando entendida em um tempo-espaço longo. Há pode haver dúvidas que esse enfraquecimento na acumulação de capital é responsável por vários dos problemas da economia, incluindo uma possível desindustrialização Outro dado importante da série é desvendar que durante o único período de crescimento considerável do produto nos anos 
2003-2010, naquilo que ficou conhecido como neodesenvolvimentismo o ritmo de acumulação foi muito aquém do necessário.

\section{Tabela 34}

Países Selecionadas da América Latina

Taxas de investimento

(\%PIB)

Décadas

\begin{tabular}{|c|c|c|c|c|c|}
\hline Período/Região & $\mathbf{1 9 8 1 - 1 9 9 0}$ & $\mathbf{1 9 9 1 - 2 0 0 0}$ & $\mathbf{2 0 0 1 - 2 0 1 0}$ & $\mathbf{2 0 1 1 - 2 0 1 8}$ & $\begin{array}{c}\text { 2011-2020 } \\
\text { (1) }\end{array}$ \\
\hline Brasil & 18,8 & 19,5 & 18,2 & 18,3 & 17,9 \\
\hline Chile & 21,1 & 26,2 & 22,0 & 23,8 & 23,6 \\
\hline Colômbia & 21,1 & 20,8 & 20,3 & 22,7 & 22,7 \\
\hline México & 24,7 & 23,0 & 22,2 & 23,1 & 23,0 \\
\hline Peru & 21,5 & 19,5 & 19,9 & 23,4 & 23,3 \\
\hline
\end{tabular}

Fontes: IBGE/FMI

Nota (1) Projeções WEO/FMI (abril de 2019)

$\mathrm{Na}$ Tabela 35 tem-se as taxas de investimento do Brasil e do grupo de quatro países. É na década de 2011-2018 que se registra a maior diferença refletindo a desordem oriunda da crise do governo Dilma e do golpe seguido de recessão corretiva.

Nas quatro últimas décadas o Brasil patinou em 18,8\% de investimento, a média dos países selecionados foi de 22,3\%. Ou seja, o Brasil investiu 3,5\% menos que o combinado de Chile, Colômbia, México e Peru. 


\section{Tabela 35}

Brasil e Média de Países Selecionados da América Latina

Taxas de investimento

(\%PIB)

Décadas

\begin{tabular}{|c|c|c|c|c|c|}
\hline Período/Região & $\begin{array}{c}\mathbf{1 9 8 1 -} \\
\mathbf{1 9 9 0}\end{array}$ & $\begin{array}{c}\mathbf{1 9 9 1 -} \\
\mathbf{2 0 0 0}\end{array}$ & $\mathbf{2 0 0 1 - 2 0 1 0}$ & $\mathbf{2 0 1 1 - 2 0 1 8}$ & $\mathbf{2 0 1 1 - 2 0 2 0}(\mathbf{1})$ \\
\hline Brasil & 18,8 & 19,5 & 18,2 & 18,3 & 17,9 \\
\hline Média (2) & 22,2 & 22,4 & 21,1 & 23,2 & 23,1 \\
\hline
\end{tabular}

Fontes: IBGE/FMI

Nota (1) Projeções WEO/FMI (abril de 2019)

(2) Média dos Países Chile, Colômbia, México e Peru

\section{Comportamento do mercado de trabalho}

Na tabela 36, tomando o IV trimestre de 2013 como o momento da reversão percebese uma redução no nível do emprego formal total de 185,05 para 178,15; uma queda aparentemente discreta de 3,7\%. Qualificar de aparentemente é adequado, pois quando se desagrega esse valor total nos setores de Industria de Transformação, Comércio, Serviços e Construção Civil, algumas conclusões são possíveis e corroboram as análises anteriores feitas neste trabalho.

Na Industria de Transformação os valores são de 157,61 e 137,70, logo uma queda de 12,6\%. No setor Comercial a variação é de apenas 1,5\%; caindo de 222,27 para 2018,84. O setor de Serviços aumenta o índice de emprego de 186,52 para 192,28; aumento, portanto, 3,0\%. A Construção Civil teve o maior recuo, isto é, de 250,40 para 173,00; logo 31,0\%. Desse modo, a análise do mercado de trabalho confirma a depressão econômica. Para máquinas paradas e sem serventia, homens desocupados e famintos. 'É o capitalismo derretendo capital". 


\section{Tabela 36}

Brasil

Índice do Nível do Emprego Formal

2010-2019

Base 2001 $=100$

\begin{tabular}{|c|c|c|c|c|c|}
\hline Período & Total & $\begin{array}{c}\text { Industria de } \\
\text { Transformação }\end{array}$ & Comércio & Serviços & $\begin{array}{c}\text { Construção } \\
\text { Civil }\end{array}$ \\
\hline $\mathbf{2 0 1 0}$ & 164,22 & 149,25 & 193,06 & 161,77 & 208,91 \\
\hline $\mathbf{2 0 1 1}$ & 173,52 & 153,52 & 204,63 & 172,35 & 228,59 \\
\hline $\mathbf{2 0 1 2}$ & 179,82 & 155,28 & 214,38 & 180,32 & 241,68 \\
\hline $\mathbf{2 0 1 3}$ & 185,05 & 157,61 & 222,27 & 186,52 & 250,40 \\
\hline $\mathbf{2 0 1 4}$ & 186,98 & 154,52 & 227,03 & 191,92 & 241,30 \\
\hline $\mathbf{2 0 1 5}$ & 179,93 & 142,89 & 221,87 & 188,97 & 206,54 \\
\hline $\mathbf{2 0 1 6}$ & 173,84 & 136,74 & 217,09 & 184,31 & 176,36 \\
\hline $\mathbf{2 0 1 7}$ & 173,79 & 136,34 & 218,21 & 184,77 & 167,68 \\
\hline $\mathbf{2 0 1 8}$ & 176,28 & 136,39 & 220,79 & 189,27 & 169,09 \\
\hline $\mathbf{2 0 1 9}(\mathbf{1})$ & 178,15 & 137,70 & 218,64 & 192,28 & 173,00 \\
\hline
\end{tabular}

Fonte: Ministério do Trabalho/Banco Central do Brasil

Nota (1) Valor de abril de 2019

Em complemento à Tabela 36, a tabela 37 apresenta Taxa de desocupação crescente desde 2013 com um "soluço" de 0,2\% em 2014, chegando a 12,7\% na projeção de 2019. Observa-se, ainda, que desde o golpe de 2016 que a taxa atingiu dois dígitos. A melhor explicação são as políticas ultraconservadoras dos governos 


\section{Tabela 37}

Brasil

Taxa de Desocupação

2012-2019

(\%)

\begin{tabular}{|c|c|}
\hline Período & Taxa \\
\hline $\mathbf{2 0 1 2}$ & 7,3 \\
\hline $\mathbf{2 0 1 3}$ & 7,0 \\
\hline $\mathbf{2 0 1 4}$ & 6,8 \\
\hline $\mathbf{2 0 1 5}$ & 8,5 \\
\hline $\mathbf{2 0 1 6}$ & 11,5 \\
\hline $\mathbf{2 0 1 7}$ & 12,7 \\
\hline $\mathbf{2 0 1 8}$ & 12,2 \\
\hline $\mathbf{2 0 1 9}(\mathbf{1})$ & 12,7 \\
\hline
\end{tabular}

Fonte: IBGE - PNADC

Nota (1) Projeção

A Tabela 38 mostra um pequeno aumento no Pessoal Ocupado com Rendimentos. Um dado que parece inconsistente, essa inconsistência pode ser relativa à natureza projetiva do dado. A massa Salarial cai pela queda dos salários e das horas trabalhadas. A Remuneração Média despenca pela queda dos salários, particularmente pelo Turnover. 


\section{Tabela 38 \\ Brasil \\ Rendimento médio real efetivo de todos os Trabalhos \\ 2018-2019 \\ Média Móvel Trimestral}

\begin{tabular}{|c|c|c|c|}
\hline Período ${ }^{(1)}$ & $\begin{array}{l}\text { Pessoal ocupado com } \\
\text { rendimento }\end{array}$ & $\begin{array}{c}\text { Massa Salarial } \\
\text { (em milhares de }_{\text {Reais })^{(3)}}\end{array}$ & $\begin{array}{c}\text { Remuneração } \\
\text { Média (em Reais) }^{(3)}\end{array}$ \\
\hline 2018 & 90.519 .000 & 235126.000 & 2610 \\
\hline $2019^{(4)}$ & 90.651000 & 208786.000 & 2294 \\
\hline
\end{tabular}

Fonte: IBGE. Pesquisa Nacional por Amostra de Domicílios Contínua

Notas:

(1) 2018, dezembro e 2019, maio

(2) Rendimento de todos os trabalhos, efetivamente recebido por mês, pelas pessoas de 14 anos ou mais de idade, ocupadas na semana de referência, com rendimento de trabalho

(3) Deflacionado pelo IPCA

(4) Projeção

\section{A economia engata a marcha à re}

Infelizmente, o pacto entre o trabalho representado, enquanto chapa-programa pelo ex-operário Luiz Inácio Lula da Silva e o capital representado pelo empresário José Alencar Gomes da Silva indicava, considerando a natureza e o caráter de nossa burguesia, um triste final para os trabalhadores e outras camadas pobres. É neste sentido que se entende o subtítulo deste capítulo, a saber, crônica de um desastre anunciado.

Sabe-se que para chegar ao poder central o Presidente Lula e seu partido, o PT fizeram diversos movimentos de acomodação. Em primeiro lugar, a constituição de uma frente ampla o bastante para incluir, além do Senador José Alencar como Vice, figuras históricas tradicionais como Orestes Quércia, Roberto Requião, José Sarney e Itamar Franco. Em segundo lugar, uma carta aos brasileiros, onde ficavam claras as intenções de bom comportamento do Partido e do candidato quanto às regras de mercado.

Os dados indicam que o período de 2003-2010, quando o presidente Lula esteve no comando do país foram de relativa prosperidade e crescimento econômico, além de esperança em avanço constantes e crescentes. Havia mesmo, apesar de em alguns casos conter exageros, uma firme crença de que o país estava se deslocando no sentido do núcleo orgânico da 
economia capitalista-mundo. Contudo, os problemas estruturais eram muitos. Esse quadro idílico foi interrompido pela crise e o golpe de 2014/2016.

O governo Dilma passou por 11 trimestres de recessão, só perdendo, então, para a recessão de 1981-1983 que, apesar de menor duração, nove trimestres, provocou um encolhimento do PIB de 8,5\% e de 13,2\% do PIB per capita. O período Dilma representou ao final um resultado não esperado se visto como possibilidade no final do governo Lula, quando se festejava um crescimento em 2010 de 7,5\%.

Deve-se reconhecer que o Presidente Lula passou não apenas a faixa presidencial, mas uma economia com vários entraves estruturais. As muitas áreas de descoordenação indicavam a necessidade de correções, caso a continuidade petista pretendesse a manutenção da aliança programática feita com o com o capital em 2002.

Com a crise mundial de 2007-2008, o presidente Lula implementou uma política contracíclica em 2009-2010, que apresentou bons resultados. Reduziu os efeitos mais sérios da crise e conseguiu recuperar em pouco tempo o crescimento, mas a crise europeia e, posteriormente, a reorientação do modelo de desenvolvimento chinês, que reduziu a demanda por commodities, provocando quedas consideráveis em seus preços, desvelaram as bases frágeis em que se assentava a promessa de um espetáculo do crescimento.

A economia que Dilma pegou tinha vários problemas. Para obter sucesso e superar as crises econômica e política uma alternativa seria romper a aliança capital-trabalho estabelecida em 2002 pelo PT. Essa ruptura, pouco provável, dado os compromissos e o poder efetivo da burguesia no governo, em tese permitiria a realização de mudanças de rumo. Seria a expressão real da Dilma Coração Valente. Uma outra saída seria dosar as concessões menos graves com a manutenção dos aspectos mais sociais dos programas de governo.

O exemplo da primeira hipótese foi o pronunciamento no dia do trabalhador de 2012 quando a presidenta afirma que os bancos operavam com uma lógica perversa, como registrado pelo Globo:

"Em pronunciamento pelo Dia do Trabalhador, exibido em rede nacional de rádio e televisão na noite desta segunda-feira (30), a presidente Dilma Rousseff cobrou redução maior nas taxas de juros por parte dos bancos privados e classificou como "inadmissível" que o Brasil, com "um dos 
sistemas financeiros mais sólidos e lucrativos, continue com um dos juros mais altos do mundo" [...] "Nosso sistema bancário é um dos mais sólidos do mundo. Está entre os que mais lucraram e isso tem the dado força e estabilidade, o que é bom para toda a economia, mas isso também permite que eles deem crédito mais barato aos brasileiros. [...] O setor financeiro, portanto, não tem como explicar esta lógica perversa aos brasileiros. A Selic baixa, a inflação permanece estável, mas os juros do cheque especial, das prestações ou do cartão de crédito não diminuem", afirmou a presidente no pronunciamento exibido na véspera do Dia do Trabalhador, comemorado no $1^{\circ}$ de maio. ${ }^{83}$

O grande problema é que a presidente Dilma nem rompeu (primeira alternativa forte), nem mesmo contemporizou (segunda alternativa mediana), mas reforçou os laços orgânicos com o capital, naquilo que a economista Laura Carvalho chamou de "Agenda FIESP" 84 .

A economista Laura Carvalho diz que a ex-presidente Dilma Rousseff tem "uma responsabilidade, sim" pela atual crise econômica, "mas não aquela que vem sendo atribuída a ela". Laura deu entrevista ao "Jornal da CBN - 2 Edição" para falar do livro que está lançando: "Valsa Brasileira, do Boom ao Caos Econômico". Segundo a economista, "não houve uma gastança" no governo Dilma. Ela lembra que as despesas públicas cresceram menos do que nos anos Lula e no segundo mandato de FHC. Laura afirma que o principal erro de Dilma foi ter adotado, a partir de 2011, o que ela chama de "agenda Fiesp", com uma política de incentivos de custo elevado. ${ }^{85}$

Um dos maiores problemas dessa Agenda foram as políticas de favorecimento ao setor industrial sob o disfarce de auxiliara a recuperação econômica e sem (algo inconcebível), alguma contrapartida por parte dos industriais com, por exemplo, políticas de preservação e aumento do emprego. Depois do maior enlaçamento com o capital e da adoção de políticas econômicas equivocadas, a economia começa a apresentar claros sinais regressivos. O conjunto da política econômica implementada, a partir de então se encarregaria, pela sua natureza de austericídio de transformar a economia brasileira em um

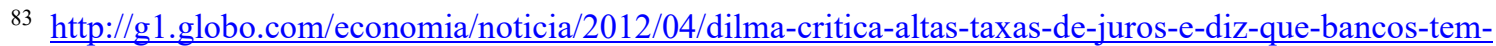
logica-perversa.html

${ }^{84} \mathrm{http}: / /$ brasildebate.com.br/critica-renovada/

${ }^{85}$ https://www.blogdokennedy.com.br/erro-de-dilma-foi-adotar-agenda-fiesp-diz-laura-carvalho/
} 
ambiente adequado aos resultados fortemente negativos que vieram.

Um balanço conjunto dos períodos Lula e Dilma sugere que ocorreu avanços no processo de redução das taxas de pobreza e de desigualdades, graças às políticas sociais implementadas. Entretanto, as taxas do crescimento do produto não foram suficientes para sustentar o conjunto das políticas. Se não havia sustentação de longo prazo, a crise e a queda na taxa de lucro cobraram a fatura. A burguesia não costuma aceitar ataques sobre a lucratividade esperada.

Uma forma mais convencional de enxergar a questão é entender que enquanto os ventos da economia capitalista mundial estufaram as velas brasileiras e a "euforia chinesa" predominou, as várias políticas que favoreciam as populações de mais baixa renda do Brasil tiveram livre transito, porém quando este círculo virtuoso deu lugar ao círculo vicioso da instabilidade e da crise, o Estado vai perdendo os instrumentos e as "capabilities" de continuar levando à frente seu projeto social de inclusão apoiado pela burguesia.

O ajuste de 2015 representa o desespero e o último segmento da queda. Nesse ponto já é possível se falar no fim de uma ilusão. Ou seja, não mais possível pensar em "crescimento com inclusão social”, nem mesmo é possível pensar em crescimento. O sonho acabou e em seu lugar fica o deserto do desemprego da precarização e da estagnação sem prazo para terminar.

Em 2016, a sociedade amarga os efeitos combinados da destruição institucional da Lava-Jato, o desgaste do processo de impeachment de Dilma e as incertezas de um vice chegando à presidência sem apoio efetivo, exceto o desejo golpista das classes dominantes. Neste sentido, não houve possibilidade real de uma política econômica ativa.

A política recessiva que a Presidenta Dilma aplicava com lentidão e uma certa indecisão, o substituto e ex-vice-presidente, Temer aplica com maior rapidez. Ao afirmar que procurará o crescimento o presidente sabe que isto não é possível, pois o resultado principal é queda nas receitas do governo e o enfraquecimento das variáveis consumo, investimentos e gastos públicos.

No ano de 2017 quase nada foi realizado para tirar a economia do poço da recessão em que ela foi metida. $\mathrm{O}$ investimento caia, a população cada dia consumia menos, enquanto o governo gastava menos e arrecadava menos ainda. Havia um tipo especial de autoengano, 
a saber, todos sabiam que as medidas eram contracionistas, mas se fingia que se estava em busca do crescimento econômico. Era como se alguém tivesse jogado o volante fora, mas acreditasse sinceramente ser possível chegar ao destino no prazo acordado.

Entre o início de seu governo e o final de 2017, Temer reduziu a taxa de juros Selic de $14,25 \%$ para $7,5 \%$, ou seja, quase a metade. É evidente que a recessão promoveu juntamente com uma queda dos preços, esta que nos juros, mas nada disso correspondeu a um aumento do investimento como reza algumas cartilhas. Os empresários estavam com a confiança baixa e/ou a relação da eficiência marginal do capital com a taxa de juros não era compensadora. Na verdade, ajudou muito mais a liberação das contas inativas do FGTS e do PIS/Pasep que significou a colocação de pouco mais de sessenta bilhões de reais no sistema, impulsionando o consumo das famílias.

Em 2018, o governo Temer e seus aliados tentam mostrar à população que com a derrubada do PT e o novo quadro de estabilidade e ausência de corrupção a economia estava respondendo as políticas e retomava a rota do crescimento. Como se pode observar na Tabela 2 acima, a Formação Bruta de Capital Fixo foi negativa de - 10,2\%; - 3,0\% e - 4,3\% em 2018. Nos três anos compostos, a taxa do produto permanece negativa, mesmo se atingindo 1,1\% em 2018. Enfim o crescimento do espetáculo era imenso com a inestimável ajuda da mídia nacional.

O governo que substituiu Dilma e que veio para moralizar a política afundava em denúncias de corrupção envolvendo malas de dinheiro. Os indicadores de popularidade ficavam abaixo de 5\%. Os processos de corrupção ficavam suspensos por conivência do Poder judiciário em todos os níveis. Assim, o governo Temer termina com popularidade baixa, mas cumpre o papel de preparar o terreno para uma alternativa de extrema-direita. Suas pretensões de se reeleger presidente ficou no desejo.

As eleições presidenciais no Brasil ocorreram em um clima de radicalização muito forte, com o principal candidato, o petista Luiz Inácio Lula da Silva preso através de um processo judicial questionado dentro e fora do país. Ao final o juiz que o condenou, Sérgio Moro, atual Ministro e o chefe dos procuradores admitiram de público que não havia provas, mas convicção.

O candidato da extrema-direita, Jair Bolsonaro, depois de uma facada não 
comprovado e questionada até hoje, em campanha em Minas Gerais, internou-se em um hospital e não participou dos debates. Por outro lado, verificou-se uma crescente e perigosa influência das redes sociais no processo eleitoral

Existem denúncias de difícil comprovação, em todo mundo, de interferência ilegítima em resultados eleitorais. A eleição de Donald Trump continua sendo questionada. No caso brasileiro a situação é diferente, pois há aceitação do fato por diversos e importantes segmentos da sociedade. Mesmo a grande imprensa, extremamente conservadora e defensora de interesses contra a população mais pobre admitiu e publicou a existência de financiadores de um esquema milionário de disparos robóticos de mensagens falsas e subliminares.

Não se tratou de formas espontâneas de participação, mas de uma ação orquestrada e caríssima no sentido de modificar as tendências do eleitorado. Pouco mais de uma semana das eleições. A própria imprensa publicou a forma e os financiadores dessa ação organizada num grande acordo ilegal entre empresários corruptos e a candidatura Bolsonaro. O IPEA (Instituto de Pesquisas Econômicas Aplicada) em publicação do mês corrente ${ }^{86}$ reconhece que ocorreu queda na atividade econômica, principalmente pelo ativismo fiscal exacerbado, mas afirma que a economia volta a crescer em 2020. A média de algumas projeções indica 0,9\% em 2019 e 2,0\% no próximo ano. Pela profundidade da queda na atividade econômica é pouco provável que essa previsão se realize.

Com a fixação do teto dos gastos públicos e a queda constante e recorrente do PIB não existem atividades econômicas capazes de gerar receita pública. Assim, fica evidente que mais uma vez a ortodoxia sufoca a economia na esperança de salvá-la. Este é o grande paradoxo do austericídio proposto pelos conservadores de plantão. A economia está tão enredada no labirinto dos donos do poder que a saída se mostra muito complicada.

Quando os formuladores das políticas econômicas só enxergam desequilíbrios das contas públicas e a questão fiscal como responsável pelas dificuldades gerais, incluindo os soluços inflacionários, o resultado é recessão induzida em uma economia já estagnada.

O mais grave é que não se tem nem a inteligência, por exemplo, do $\mathrm{PAEG}^{87}$, pois não

\footnotetext{
${ }^{86}$ IPEA. CARTA DE CONJUNTURA, $\mathrm{n}^{\circ} 45,4^{\circ}$ trimestre de 2019.

${ }^{87}$ O Programa de Ação Econômica do Governo (PAEG) foi o primeiro plano econômico do governo brasileiro depois do Golpe militar de 1964. O plano não tinha por interesse favorecer as classes baixas da sociedade
} 
há interação entre as ações. Na verdade, o governo de Bolsonaro se limita a reduzir a demanda, atacar direitos e privatizar ou reduzir a inanição as estruturas públicas, como feito com as Universidades Federais.

Sem floreios e otimismo irrealista qual é a trajetória do passado recente e as possíveis projeções futuras? De 2011 a 2013 a economia manteve um crescimento médio anual de 3,0\%; entre 2014 e 2015 o PIB brasileiro caiu em 1,5\% e de 2016 a 2019 a queda continua em $0,15 \%$. Os dados estão disponíveis na tabela 1 , página 4 acima.

Qualquer estimativa realista, se mantido o ritmo atual da economia, com Bolsonaro na presidência e o economista Paulo Guedes no comando do Ministério da Economia, o PIB per capita de 2011 só será alcançado entre 2024 e 2025.

Se a economia real afunda, o setor financeiro obtém lucros crescentes no meio da crise e do desespero social. Os bancos nesse último período aumentaram as tarifas algo em torno de 12-15\%. Em parte, os fabulosos lucros financeiros se devem ao alto nível de concentração do setor. No Brasil, cinco bancos, a saber, Itaú/Unibanco, Bradesco, Santander, Banco do Brasil e Caixa Econômica Federal acumulam em torno de 80\% dos depósitos. Em parte, os lucros financeiros estão relacionados com a dívida pública

Relatórios do DIEESE demonstram que um dos motivos principais da excepcional evolução da lucratividade bancária é explicada pela expansão das receitas dos bancos com aplicações em Títulos e Valores Mobiliários (principalmente, títulos da dívida pública federal), que tem representado em média $43 \%$ da receita dos bancos nos últimos dois anos, por conta da alta da taxa básica de juros, ou Taxa Selic ${ }^{88}$.

A taxa referencial de juros (taxa Selic), oscila hoje (setembro de 2019) em torno de $5,0 \%$, é das menores por décadas e o mercado trabalha com estimativas de que pode diminuir ainda mais. Significa dizer que mesmo a ortodoxia está convencida da necessidade de ajustar a taxa de juros às necessidades da economia real.

brasileira, já que elas estavam impedidas de protestar contra qualquer medida governamental ${ }^{88} \mathrm{https://www.dieese.org.br/desempenhodosbancos/2018/desemprenhoDosBancos2017.html}$ 


\section{Referências}

ABREU, Marcelo de Paiva (Org.). A Ordem do Progresso: cem anos de política econômica republicana (1889-1989). Rio de Janeiro: Campus, 1992.

AGLIETA, M. \& ORLEANS, A. A violência da moeda. São Paulo: Brasiliense, 1990.

BANCO CENTRAL DO BRASIL. Análise do mercado de câmbio, 1998.

BANCO CENTRAL DO BRASIL. Boletim, vários números.

BANCO CENTRAL DO BRASIL. Diretoria de Política Econômica/Departamento Econômico. Nota para a imprensa. Diversos números. Disponível em http://www.bcb.gov.br . Diversos acessos.

BANCO CENTRAL DO BRASIL. Relatório Anual, vários anos.

BARBOSA, Glaudionor Gomes e CAVALCANTI, Guilherme de Albuquerque. Investimento, poupança e crédito: uma comparação preliminar entre as abordagens de Kalecki e Schumpeter. UFPB, 2000.

BATISTA JR., Paulo Nogueira. Novos ensaios sobre o setor externo da economia brasileira. Rio de Janeiro: FGV, 1988a.

BATISTA JR., Paulo Nogueira. Da crise internacional à moratória brasileira. Rio de Janeiro: Paz e Terra, 1988b.

BATISTA JR., Paulo Nogueira. Mito e realidade na dívida externa brasileira. Rio de Janeiro: Paz e Terra, 1983.

BATISTA JR., Paulo Nogueira. O Consenso de Washington: A Visão Neoliberal dos Problemas Latino-Americanos. Consulta Popular, 1994.

BNDES. A economia brasileira nos anos noventa. Rio de Janeiro: BNDES, 1999. Disponível em: http://www.bndes.gov.br. Acesso em 12 de abril de 2010.

BNDES. Balanço da privatização no Brasil. Rio de Janeiro: BNDES, 2001. Disponível em: http://www.bndes.gov.br. Acesso em 19 de abril de 2010.

BRASI. II Plano Nacional de Desenvolvimento (II PND) - 1975/1979, set.1974.

CAMARGO, José Márcio \& RAMOS, Carlos Alberto. A revolução indesejada: conflito distributivo e mercado de trabalho. Rio de Janeiro: Campus, 1988. 
CARNEIRO, Dionísio Dias \& MODIANO, Eduardo. Ajuste externo e desequilíbrio interno: 1980-1984. In: ABREU, Marcelo de Paiva (Org.). A Ordem do Progresso: cem anos de política econômica republicana (1889-1989). Rio de Janeiro: Campus, 1992.

CARNEIRO, Dionísio Dias. Política econômica da Nova República. São Paulo: Bienal/Unicamp, 1986.

CARNEIRO, Dionísio Dias. Política econômica do Cruzado. São Paulo: Bienal/Unicamp, 1987.

CARNEIRO, Dionísio Dias. Desenvolvimento em Crise: a economia brasileira no último quarto do século XX. São Paulo: Unesp, 2002.

CARNEIRO, Luciene; COSTA, Daiane. Comitê da FGV afirma que recessão recente foi a mais longa e mais intensa desde anos 80. Disponível em:

https://oglobo.globo.com/economia/comite-da-fgv-afirma-que-recessao-recente-foi-maislonga-a-mais-intensa-desde-anos-80-22008223 Acesso em: 10 de agosto de 2019.

Comitê de Datação de Ciclos Econômicos (CODACE). IBRE. FGV/RJ. Disponível em: https://portalibre.fgv.br/data/files/F3/C1/F8/E8/A18F66108DDC4E66CA18B7A8/Comite $\% 20 \mathrm{de} \% 20 \mathrm{Data} \mathrm{0} \% 20 \mathrm{de} \% 20 \mathrm{Ciclos} \% 20 \mathrm{Econ} \operatorname{micos} \% 20$ \%20Comunicado $\% 20 \mathrm{de} \% 2030 \quad 10 \_2017 \% 20 \_1$ _.pdf Acesso em 05 de agosto de 2019

DIEESE. Dez anos de política salarial. Estudos Sócio-Econômicos no 3, São Paulo, ago.1975.

DIEESE. Desempenho dos Bancos - 2017. Disponível em: https://www.dieese.org.br/desempenhodosbancos/2018/desemprenhoDosBancos2017.html Acesso em: 10 de setembro de 2019.

DRUMMOND, Carlos. Dilma errou ao seguir a 'agenda Fiesp', diz economista. Disponível em: http://brasildebate.com.br/critica-renovada/ Acesso em 10 de agosto de 2019

ÉPOCA, No 713, 16 de janeiro de 2012. pp. 32-49.

EXAME. Melhores e maiores. Vários números.

FIBGE. Anuário Estatístico do Brasil. Vários anos.

FIBGE. Departamento de Estudos de Indicadores Sociais. Indicadores Sociais: tabelas selecionadas 1979.

FIBGE. Estatísticas históricas do Brasil.

FIBGE. Pesquisa industrial mensalde emprego e salário. Disponível em: 
http://www.ibge.gov.br/home/presidencia/notícias/noticia. Diversos acessos.

FIBGE. Pesquisa Mensal de Emprego. Vários números.

FIBGE. Pesquisa Nacional por Amostra a Domicílios (PNAD). Vários números.

FIBGE. Estatística. Indústria. Disponível em: https://www.ibge.gov.br/estatisticas/economicas/industria.html Acesso em: 12 de agosto de 2019.

FIBGE. Estatística. Contas Nacionais. Disponível em: https://www.ibge.gov.br/estatisticas/economicas/contas-nacionais.html Acesso em: 15 de agosto de 2019.

FILGUEIRAS, Luiz \& GONÇALVES, Reinaldo. A economia política do governo Lula. São Paulo: Contraponto, 2007.

FOLHA DE SÃO PAULO. Online. Vários acessos.

FOLHA DE SÃO PAULO Vários números, março a setembro de 1986.

FUNDO MONETÁRIO INTERNACIONAL (FMI). World economic outlook database. Setembro/outubro de 2010. Disponível em: http://www.imf.org. Vários acessos.

FMI. World Economic Outlook, April 2019. Disponível em: https://www.imf.org/en/Publications/WEO/Issues/2019/03/28/world-economic-outlookapril-2019 . Acesso em: 10 de agosto de 2019.

G1 GLOBO ECONOMIA. Em fala do Dia do Trabalhador, Dilma diz que bancos têm "lógica perversa" Disponível em: http://g1.globo.com/economia/noticia/2012/04/dilma-critica-altas-taxas-dejuros-e-diz-que-bancos-tem-logica-perversa.html Acesso em 07 de agosto de 2019

IBRE/FGV/RJ. Em 2018, aproximadamente 90\% dos países do mundo apresentaram uma taxa de investimento maior do que a do Brasil. Disponível em: https://blogdoibre.fgv.br/posts/em-2018-aproximadamente-90-dos-paises-do-mundoapresentaram-uma-taxa-de-investimento-maior-do Acesso em: 10 de agosto de 2019

INSTITUTO DE ESTUDOS PARA O DESENVOLVIMENTO INDUSTRIAL - IEDI. Indústria e desenvolvimento. Uma análise dos anos 90 e uma agenda de política de desenvolvimento industrial para a década. São Paulo: IEDI, 2000.

INSTITUTO DE ESTUDOS PARA DESENVOLVIMENTO INDUSTRIAL. Análise IEDI: PIB Trimestral - O sol e a peneira, 2005. Disponível em: http://www.acionista.com.br/mercado/artigos_mercado/301105 pib.htm. Acesso em: $22 \mathrm{de}$ dezembro de 2011. 
IPEA. Mercado de trabalho, conjuntura e análise, $n^{\circ}$ 5, Julho de 1997.

IPEA.Perspectivas da economia brasileira 1994. Rio de Janeiro, 1993. IPEADATA. http://www.ipeadata.gov.br/. Vários Acessos.

IPEA. MACROECONÔMICO. Disponível em: http://www.ipeadata.gov.br/Default.aspx Vários acessos em agosto-setembro de 2019.

IPEA. CARTA DE CONJUNTURA, $\mathrm{n}^{\mathrm{o}} 45,4^{\mathrm{o}}$ trimestre de 2019. Disponível em: http://www.ipea.gov.br/portal/index.php?option=com_content\&view=article\&id=34894\&It

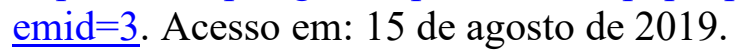

KENNEDY, Alencar. Erro de Dilma foi adotar "agenda Fiesp", diz Laura Carvalho. Disponível em: https://www.blogdokennedy.com.br/erro-de-dilma-foi-adotar-agenda-fiespdiz-laura-carvalho/ Acesso em 05 de agosto de 2019

LAFER, Celso. O planejamento no Brasil: observações sobre o Plano de Metas (1956/1961). In: MINDLIN LAFER, B. (Org.) Planejamento no Brasil. São Paulo: Perspectiva, 1970.

LAMUCCI, Sérgio. Taxa de investimento é a menor em 50 anos. Disponível em: https://www.valor.com.br/brasil/6321899/taxa-de-investimento-e-menor-em-50-anos

Acesso em 05 de agosto de 2019

LESSA, Carlos. A estratégia de desenvolvimento 1974/1976 - sonho e fracasso. São Paulo: Brasiliense, 1977.

MDIC. Diagnóstico da indústria brasileira, 1998. Disponível em: http://www.mdci.gov.br . Acesso em 03 de março de 2001.

MDIC. Evolução do comércio exterior brasileiro 1950/2005. Disponível em: http://www.desenvolvimento.gov.br/arquivo/secex/evocoxtbrasil. Vários acessos.

MERCADANTE, ALOIZIO (Org.). Brasil: a construção retomada. São Paulo: Terceiro Nome, 2010.

MERCADANTE, Aloizio. O Brasil pós-real: a política econômica em debate. Campinas/São Paulo: Unicamp, IE, 1998.

MINISTÉRIO DA FAZENDA. Carta de intenção referente ao novo acordo. Brasília, 2004. Disponível em: http://www.fazenda.gov.br. Acesso em 10 de setembro de 2011

MINISTÉRIO DA FAZENDA. Política econômica e reformas estruturais. Brasília, 2003. Disponível em: http://www.fazenda.gov.br. Acesso em 02 de setembro de 2011 
MINISTÉRIO DA FAZENDA. Reformas microeconômicas e crescimento de longo prazo. Brasília, 2004. Disponível em: http://www.fazenda.gov.br. Acesso em 10 de setembro de 2011

MINISTÉRIO DO PLANEJAMENTO E COORDENAÇÃO ECONÔMICA. Programa de ação econômica do governo: 1964-1966. Rio de Janeiro, 1964.

MINISTÉRIO DO PLANEJAMENTO, ORÇAMENTO E GESTÃO. Plano Brasil de todos: participação e inclusão. Brasília, 2003.

MODIANO, Eduardo. A ópera dos três Cruzados: 1985-1989. In: ABREU, Marcelo de Paiva (Org.). A Ordem do Progresso: cem anos de política econômica republicana (1889-1989). Rio de Janeiro: Campus, 1992.

NERI, Marcelo Cortes. Consumidores, produtores e a nova classe média: miséria, desigualdade e determinantes das classes. Rio de Janeiro: FGV/IBRE, 2009. Disponível em:

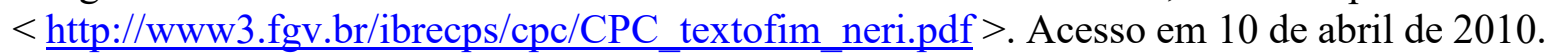

ORENSTEIN, Luiz; SOCHACZEWSKI, Antônio. Democracia com desenvolvimento (1956-1961). In: ABREU, Marcelo de Paiva (Org.). A Ordem do Progresso: cem anos de política econômica republicana (1889-1989). Rio de Janeiro: Campus, 1992.

PARTIDO DOS TRABALHADORES. PT 20 Anos. Linha Direta, Porto Alegre, $\mathrm{n}^{\circ}$ 77, fev., 2000.

PARTIDO DOS TRABALHADORES. Concepção e diretrizes do programa de Governo do PT para o Brasil. Disponível em: http://www.pt.org.br. Acesso em 15 de maio de 2011.

PARTIDO DOS TRABALHADORES. Programa de Governo 2002. Disponível em: http://www.pt.org.br. Acesso em 15 de maio de 2011.

SEPLAN. Programa de Ação Imediata (PAI). Brasília, 1993.

SEPLAN-PR. I Plano Nacional de Desenvolvimento da Nova República (I PND-NR). Brasília, 1985.

SEPLAN-PR. Notas para o I PND da Nova República:, diretrizes gerais de política econômica, Brasília, 1985.

SINGER, Paul__. A crise do "milagre”: interpretação crítica da economia brasileira. Rio de Janeiro, Paz e Terra, 1976.

SINGER, Paul O dia da lagarta: democratização e conflito distributivo no Brasil do Cruzado. São Paulo: Brasiliense, 1987. 
SUNKEL, O \& GRIFFITH- JONES, S. O fim de uma ilusão: as crises da dívida e do desenvolvimento na América Latina. São Paulo: Brasiliense, 1990. 


\section{SOBRE O AUTOR}

GLAUDIONOR GOMES BARBOSA é historiador e economista. Mestre em Economia e Doutor em Ciência Política. Concursado na área de História Econômica. Professor e pesquisador da Universidade Federal de Pernambuco. Vice-lider do Grupo de Estudos e Pesquisa em Economia Política e História Econômica. Autor das seguintes obras: Distribuição Funcional da Renda; Introdução às Teorias Monetárias e Financeiras; Política Salarial, Distribuição de Renda e Conflito no Brasil; Ensaios no Campo da Filosofia Econômica; Uma Breve Introdução ao Pensamento de John M. Keynes; SistemaMundo e Semiperiferia; História Social Inglesa: uma história "vista de baixo". 